
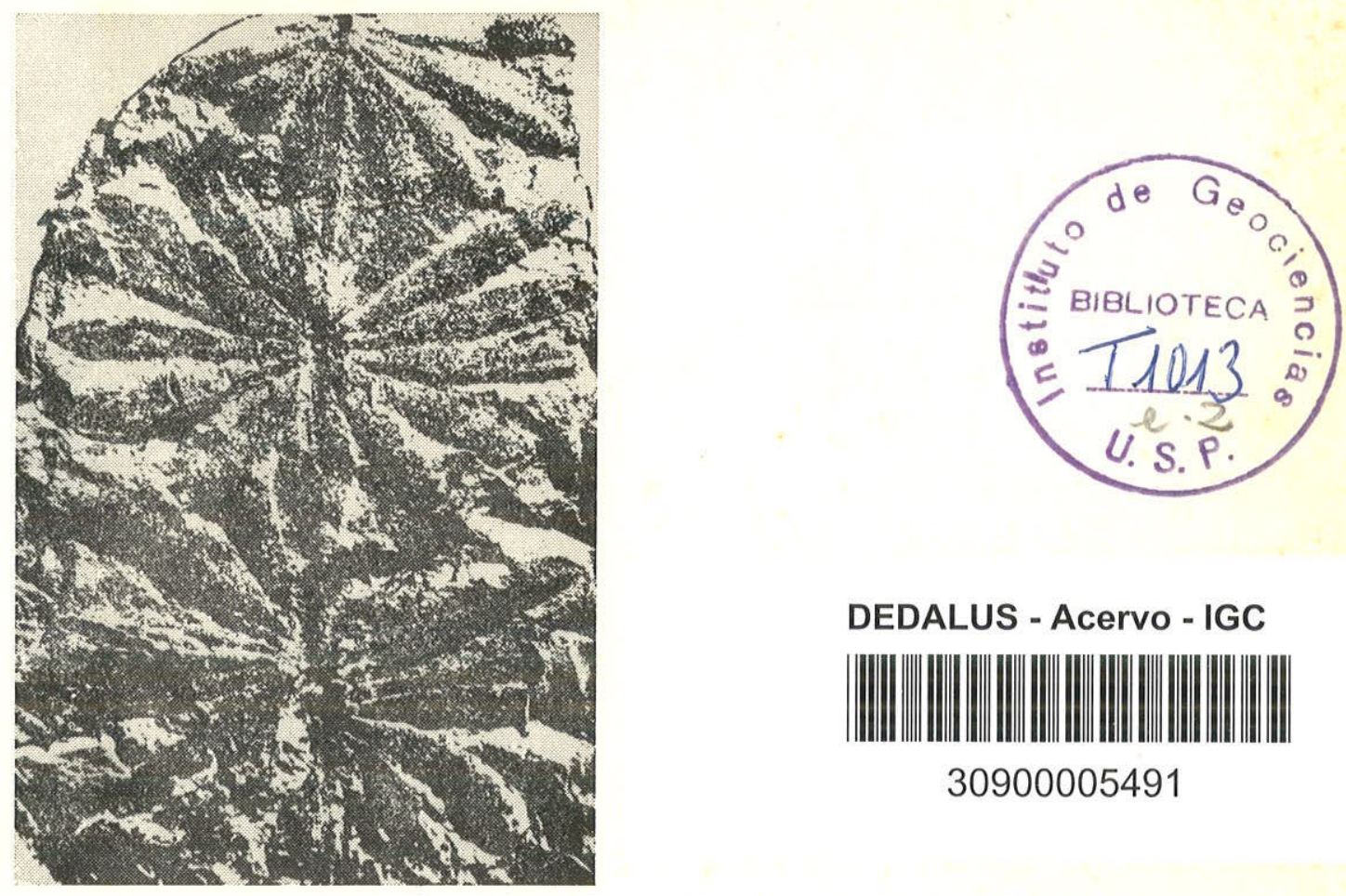

DEDALUS - Acervo - IGC

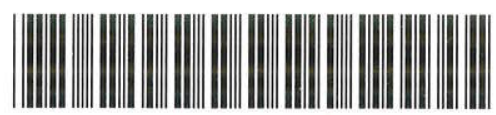

30900005491

\title{
FLORA DA FORMAÇÃO RIO BONITO DO ESTADO DO PARANÁ
}

\author{
(Tese de Doutoramento) \\ OSCAR RÖSLER \\ 1972
}

\author{
UNIVESIDADE DE SRO PAULO
BIBLIOTECA CENTBAL \\ $1 b_{1}-16$ \\ UNIVERSIDADE DE SÃO PAULO \\ INSTITUTO DE GEOCIENCIAS
}




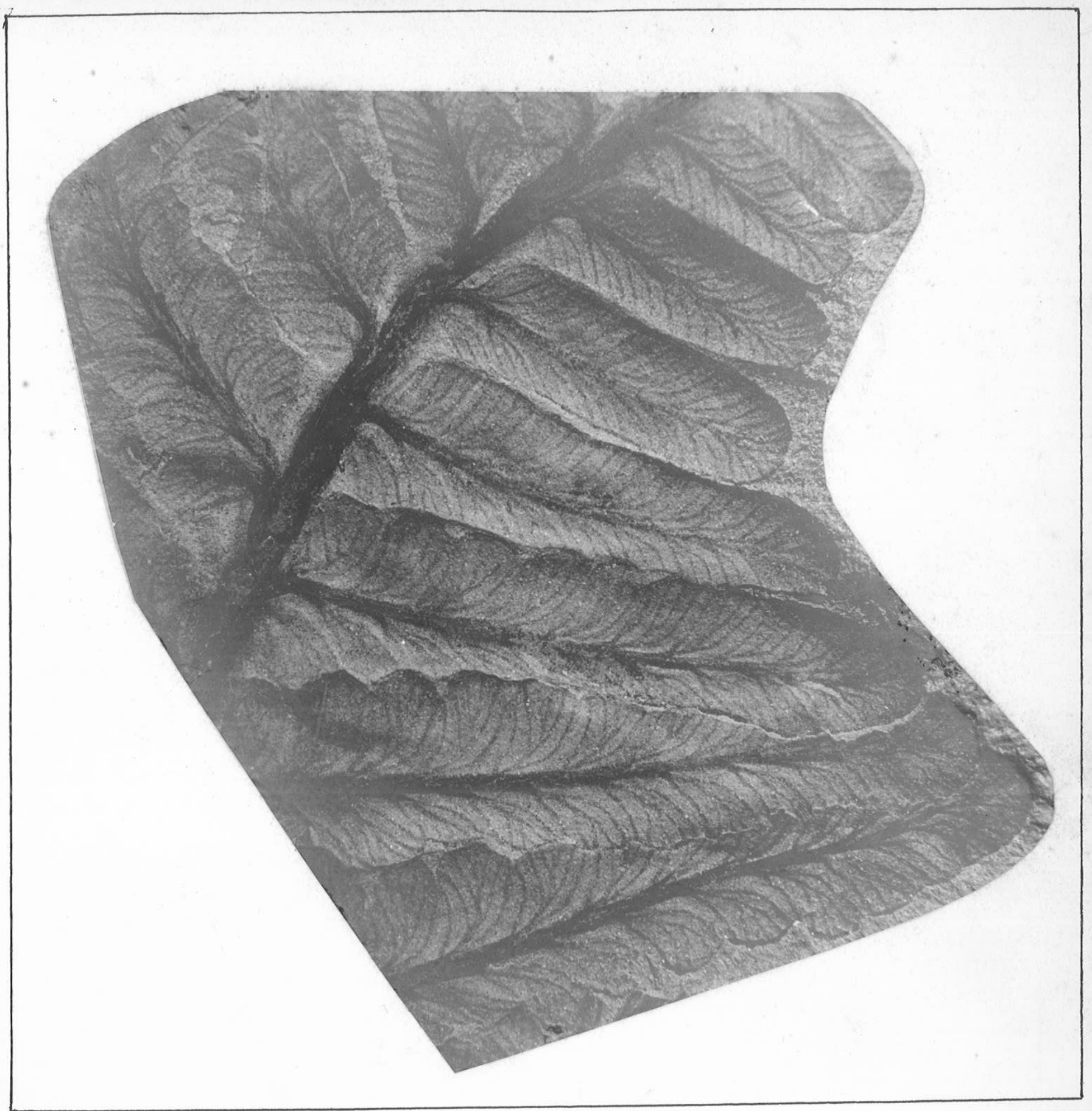

Asterotheca cambuhyensis (Read) - Testemunhando um passado de cêrca de 270 milhões de anos!

Proc.: São João do Triunfo Paranä.

Formação Rio Bonito - Grupo Tubarão . 
pāg .
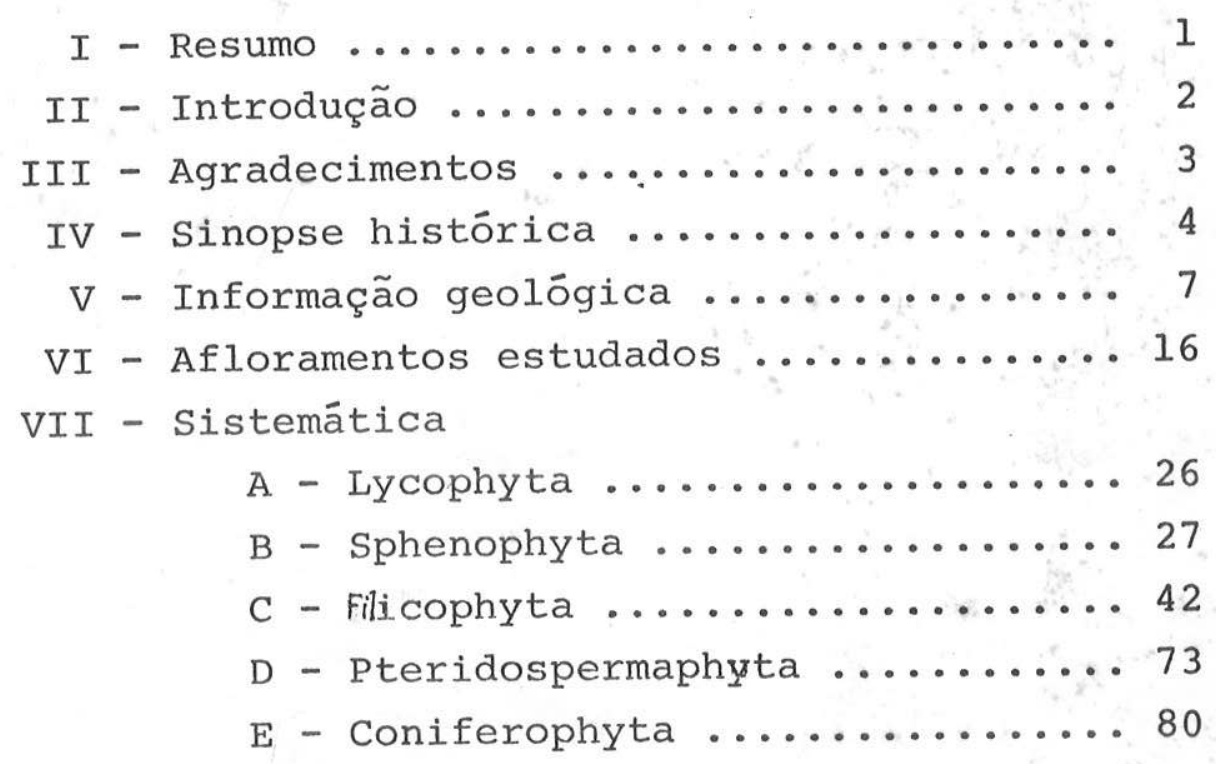

VIII - Ambiente de sedimentação da camada fossilifera ............. 84

IX - Correlação entre as ocorrências do Paraná ...................... 88

X - Correlação com outras ocorrências ..................... 92

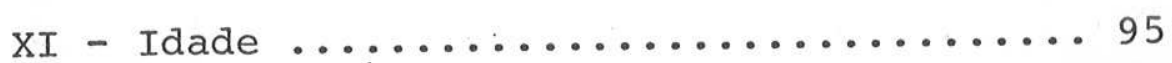

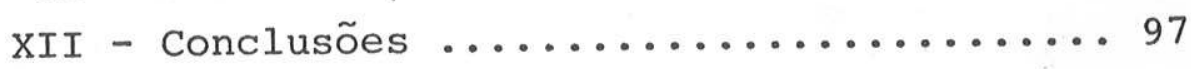

Tabela 1 - Asterotheca derbyi

(frondes férteis) ...........998

Tabela 2 - Asterotheca cambuhyensis

(frondes férteis) .......... 105

Tabela 3 - Asterotheca derbyi

(frondes estéreis) ......... 109

Tabela 4 - Asterotheca cambuhyensis

(frondes estēreis) .......... 113

Tabela 5 e 6 - Annularia occidentalis ... 115

Tabela 7 a 11 - Distribuição das

formas encontradas ......... 117

Bibliografia ..................... 122 
$I-R E S U M O$

Esse trabalho apresenta um estudo geral sobre as formas de vegetais fōsseis que ocorrem na Formação Rio Bonito no Estado do Paraná. São descritas quatro espécies novas: Sphenophyllum brasiliensis, Annularia readi, A. occidentalis e Asterotheca derbyi. Verificou-se que Pecopteris cambuhyensis Read e P. pedrasica Read correspondem a frondes estéreis de uma só espé cie A. cambuhyensis (Read) n. comb. As demais espécies são submetidas a um estudo crítico, com base no exame das coleções orga nizadas com essa finalidade. Uma lista da composição florística dessas camadas é elaborada. Essa composição revelou-se muito pe culiar em relação às demais conhecidas para a Bacia do Paraná. Entre as diferentes ocorrências no Gondwana, essa associação apresenta maior afinidade com a flora permiana da Patagônia. № tou-se grande abundância de formas "nórdicas", representadas prin cipalmente por Asterotheca, alēm de Sphenophyllum, Annularia , Pecopteris e Sphenopteris. Considera-se aspectos ligados a possiveis antigos fluxos migratórios dessas formas. E sugerida a idade permiana inferior para a base da Formação Rio Bonito. Considerações sobre a gênese das camadas que contêm a flora estudada são feitas neste trabalho. 


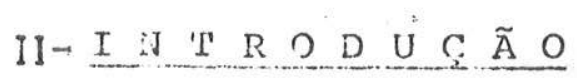

Excelentes trabalhos têm sido dedicados ao le vantamento das floras neopaleozóicas da parte brasileira da Bacia do paranā. Com mais frequência, esses estudos têm visado as ocorrências no Estado de Santa Catarina. Estudos dessa natureza, entretanto, são poucos em relarão ao Estado do Paraná, citandose a monumental monografia de Read (1941). Nos últimos anos, ne nhuma obra mais ampla foi realizada nesse sentido.

Jà há uns oito anos, o notável paleobotânico brasileiro, Elias Dolianiti, nos comunicou verbalmente, o fato de que o Estado do Paraná apresenta grande interesse sob o ponto de vista paleoflorístico. Naquela ocasião, nos apontou a localidade de Cambuí como a maịs importante nesse estado.

Motivado pelo entusiasmo então despertado mantivemos o desejo de realizarmos um estudo sobre aqueles afloramentos. Finalmente, há pouco mais de um ano e meio, iniciamos a execução de um projeto de pesquisa, visando o estudo da flórula daquela região. No transcorrer do trabalho estendemos a área de estudo para toda a faixa aflorante da Formação Rio Bonito, na quele estado, o que veio a resultar no presente trabalho.

Com a descoberta de novos afloramentos, verificou-se a abundância e qualidade excepcional de muitas das formas que lá ocorren. Essa constatação não deixa dūvidas quanto às perspectivas existentes paxa a realização de inúmeros trabalhos que ainda se seguirão. O conhecimento da nossa flora paleozóica é ainda incipiente. O presente trabalho pretende se consti- 
tuir numa pequena, mas efetiva contribuição ao seu conhecimento. Procuramos dar mais ênfase aos gêneros e espé cies julgados como de maior importầncia. Na análise da composição dessa flora, consideramos as formas cuja existência pôde ser constatada atravēs das coletas ora realizadas. Consideramos aị da, aquelas que, embora não encontradas por nós, acham-se descrí tas e figuradas adequadamente. Objetivamos com isso, ampliar o conhecimento daquela composição. Acreditamos porém que aquilo, que ora apresentamos se constitui apenas numa pequena parte da associação paleoflorỉstica que num futuro prôximo virá a ser conhecida.

\section{III-A GR A DECIMENTOS}

Somos imensamente gratos, de um modo especial às seguintes pessoas: ao Prof. Dr. Josué Camargo Mendes nosso orientador da tese de doutoramento, pelas valiosas sugestões que nos prestou, bem como pelas cri ticas e sugestões ao manuscrito; ao Dr. Elias Dolianiti pelo apoio e estímulo inicial; ao Dr. Sérgio Archangelsky, da Universidade Nacional de La Plata, Argentina, pelas valiosas sugestões; ao Dr. Oscar G. Arrondo, por nos facilitar o estudo da preciosa coleção paleobotânica do Museo de La Plata; ao Dr. Carlos Alberto Menendez por nos facilitar o estudo da coleção paleobotānica do Museo Bernardino Rivadavia, B. Aires; à Dra. Josefine D. Cabrera por nos facilitar o estudo da coleção paleobotânica do Instituto Miguel Lillo , Tucuman; ao Dr. Antonio C. Rocha Campos, por nos esclarecer algumas dūvidas referentes à Estratigrafia, bem como sobre algumas técnicas especiais; aos Srs. Rodi A. Medeiros e Antonio Thomaz Fọ (da Petrobrās); ao Sr. Luiz Mantovani e a todos aqueles que nos prestaram valiosa colaboração nos trabalhos de campo; aos estimados colegas do Instituto de Geociencias, da USP, pe1o incentivo recebido; a todos os funcionārios, desse mesmo Instituto, que com gran de esforço e compreensão tudo fizeram para que pudéssemos concluir essa obra; à Srța. Jūtia Yasokawa pelo paciente trabalho datilogräfico; a mirha esposa, muito mais que a ajuda prestada, agradeço a compreensão pelo nosso ideal. Meu sincero agradecimento ao amigo Fausto Pires de Campos a quem se deve a quali dade das estampas que ilustram o presente trabalho.

Finalmente, de um modo muito especial, somos profunda mente gratos, à Fundação de Amparo à Pesquisa do Estado de São Paulo, pelo auxîlio financeiro à primeira parte da presente pesquisa. 


\section{IV-SINOPSE HISTORICA}

Os fösseis vegetais do Paranā têm sido objeto de estudo por pesquisadores brasileiros e de outras nacionalidades. Uma das primeiras coleções dessa flora a ser submetida a es tudo foi aquela formada pelo Dr. P. Dusen em sua viagem ao Brasil. Esse material foi estudado por Lundqvist (1919) e em parte revisto por Florin (1940).

Outra coleção foi formada pelo Dr. Euzébio de Oliveira. Esse autor cita e ilustra a ocorrência de algumas for mas, em seu trabalho sobre a geologia e recursos minerais daquele estado (Oliveira, 1927). Essa coleção de plantas fōsseis do Paraná, passou a pertencer ao então Serviço Geológico e Mineralógico do Brasil. Parte dessa coleção, juntamente com material de Santa Catarina, foi enviado em 1929, pelo Dr. Euzébio de Oliveira, então diretor daquela entidade, ao Dr. David White, do Serviço Geológico dos Estados Unidos da América do Norte.

o prōprio Dr. White iniciou o estudo desse ma terial, trabalho esse que não pôde continuar por ter adoecido gra vemente, vindo a falecer em 1935. Esse estudo foi continuado pelo Dr. Charles B. Read, que desde 1930, trabalhava com o Dr. Whi te. Os resultados conseguidos por Read foram publicados no Brasil em 1941, numa das Monografias da Divisão de Geologia e Mineralogia do DNPM, conforme pedido do então diretor dessa institui ção, Sr. Glycon de Fàiva.

O trabalho de Read (1941) contém um estudo so bre as floras neopaleozóicas da Amërica do Sul, seguida da descrição do material brasileiro (Paraná e Santa Catarina). Constitui, sem dúvida, a mais importante obra publicada sobre a flo- 
ra neopaleozóica do Estado do Paranā.

Dolianiti (1954), revendo o material, ainda restante, das coleções feitas pelo Dr. E. Oliveira da localidade de Teixeira Soares, descreve Glossopteris orbicularis.

Vários outros trabalhos fazem menção ou discutem a existência de fósseis vegetais nessas camadas no paraná. Em geral se referem a trabalhos anteriores. Recentemente, Rigby (1970) apresentou um estudo sobre a distribuição das plantas do Gondwana inferior, na Bacia do Paraná. Nesse trabalho, expõe os resultados de uma revisão das floras de diferentes localidades do sul do Brasil. Com relação às localidades paranaenses, Rigby (op. cit.) baseou-se principalmente em dados bibliogräficos, dada a escassez de coleções referentes àquele estado.

Existem também alguns trabalhos compreensivos, incluindo referências sobre a paleoflora do Paraná. Entre esses Citamos: Dolianiti (1948), Mendes (1952), Barbosa (1958) e Dolianiti (1972).

Como vemos pelo exposto acima, o nümero de trabalhos que tratam especificamente dessa flora, não ē grande. Esse aspecto, como já dissemos acima, apresenta elevado contraste com o que jā se tem feito sobre o assunto, em Santa Catarina, onde se destacam os numerosos trabalhos do Dr. Elias Dolianiti e o de Oliveira (1969).

Não podemos esquecer que muitas das coleções de fósseis vegetais anteriormente formadas e estudadas, indiretamente estão ligadas a atividades de prospeçção e exploração do carvão. Tais fósseis ocorrem preferencialmente associadas a essas jazidas. Vários trabalhos foram publicados a respeito dessas jazidas. O conhecimento dos aspectos envolvidos com as mes- 
mas, de um modo geral, contribuem para esclarecer alguns aspectos ligados às plantas fósseis. Entre vārios outros, citamos os trabalhos de Amaral (1940), Decourt (1940), Dutra (1940), Leinz (1940), Oliveira (1953), Paiva (1940) e Paula (1940). O único, dentre esses, a tratar mais efetivamente dos aspectos geológicos, paleoambientais e genéticos em relação ao carvão e das cama das associadas, ē o de Leinz (1940).

Devemos ainda destacar as obras de Almeida (1945), Lange (1954), Leinz (1937), Mau (1958), Mempel (1957) , Mendes et al. (1966), Rocha Campos (1967), Northfleet et al.(1969), entre tantos outros. Embora esses trabalhos não tratem especifi camente do assunto aqui tratado, tiveram grande importância no de senvolvimento do que hoje se conhece sobre a paleontologia e principalmente Estratigrafia das camadas aqui tratadas. Nesse sentido, nosso pensamento se volta, ainda mais uma vez, à fundamental obra de White (1908). 


\section{V - INFORMAÇ̃̃O GEOLÖGICA}

Os afloramentos paranaenses, cujo conteúdo fossiliffero é estudado no presente trabalho, constituem exposições da unidade litoestratigräfica, conhecida sob a denominação de Formação Rio Bonito (Subgrupo Guatá - Grupo Tubarão). o Grupo Tubarão representa uma das grandes unidades da Bacia do Paraná.

Estudos compreensivos sobre a estratigrafia da parte brasileira dessa Bacia, foram apresentados por Mendes (1967) e Rocha Campos (1967). Algumas idéias e informações gerais sobre esse conjunto estratigräfico podem ser também encontrados nos trabalhos de Daemon et Quadros (1969) Northfleet et al.(1969) e Fulfaro et al. (1971). Um excelente resumo, encontra-se em Rocha Campos (1972), o qual adota a seguinte nomenclatura e classificação para as unidades do Paleozōico superior:

\begin{tabular}{|l|l|l|}
\hline GRUPOS & SUBGRUPOS & FORMAÇÕES \\
\hline \hline Passa Dois & & $\begin{array}{l}\text { Rio do Rasto } \\
\text { Estrada Nova } \\
\text { Serra A1ta } \\
\text { Irati }\end{array}$ \\
\hline \multirow{2}{*}{ Tubarão } & Guatá & Palermo \\
& Rio Bonito \\
\hline
\end{tabular}


O limite inferior do Grupo Tubarão apresen ta-se discordante em relação às rochas do Embasamento (Precam bíano) ou sedimentos das Formações Furnas e Ponta Grossa (Devoniano), as quais se sobrepõe. A parte superior desse grupo é seguida pelo Grupo Passa Dois que se the sobrepõe concordan temente.

\section{Grupo TUBARÃO}

Segundo Rocha Campos (1967), a parte brasileira do Grupo Tubarão se estende por uma ārea maior que 1.000.000 de quilômetros quadrados, abrangendo partes dos Estados de Mato Grosso, Goiās, Minas Gerais, São Paulo, Paraná, Santa Catarina e Rio Grande do Sul. Os afloramentos são encontrados ao longo de duas faixas alongadas, uma no bordo les te, e outra, menor, no bordo oeste da Bacia. são conhecidos sedimentos considerados equivalentes, também nas áreas dos paí ses situados a sul e sudoeste do Brasil, ou seja: Uruguai, A $\underline{r}$ gentina e Paraguai. O máximo de espessura, a qual foi verifí cada no sudeste do Estado de Mato Grosso, e sudoeste do Estado de são Paulo, atinge cerca de $1.500 \mathrm{~m}$.

Esse grupo apresenta-se geralmente com grande variação faciológica lateral, sendo que as formações e membros que o compõe, recebem nomes distintos conforme a re gião. A classificação estratigrā́fica para o Grupo Tubarão , nos Estados de São Paulo e Paranā (Rocha Campos, 1972, p. 8), è a seguinte: 


\begin{tabular}{|c|c|c|c|c|}
\hline \multicolumn{3}{|c|}{$\begin{array}{lllllllllllllll}P & A & R & A & N & \bar{A}\end{array}$} & \multicolumn{2}{|r|}{ PAULO } \\
\hline \multirow{4}{*}{$\begin{array}{l}\mathrm{G} \\
\mathrm{R} \\
\mathrm{U} \\
\mathrm{P} \\
0\end{array}$} & \multirow{4}{*}{$\begin{array}{l}\text { Subgrupo } \\
\text { Guatā }\end{array}$} & \multirow{2}{*}{$\begin{array}{l}\text { Formação } \\
\text { Palermo }\end{array}$} & \multirow{4}{*}{$\begin{array}{l}\text { Formação } \\
\text { Itapetininga }\end{array}$} & Membro Taquaral \\
\hline & & & & Membro Tatuí \\
\hline & & \multirow{2}{*}{$\begin{array}{l}\text { Formação } \\
\text { Rio Bonito }\end{array}$} & & Membro Tupi \\
\hline & & & & Tilito Pitanga \\
\hline \multirow{4}{*}{$\begin{array}{l}\mathrm{T} \\
\mathrm{U} \\
\mathrm{B} \\
\mathrm{A} \\
\mathrm{R} \\
\widetilde{\mathrm{A}} \\
0\end{array}$} & \multirow{4}{*}{$\begin{array}{l}\text { Subgrupo } \\
\text { Itararé }\end{array}$} & & Fm. Tiet $\widehat{e}$ & Tilito Jumirim \\
\hline & & & Fm. Gramadinho & $\begin{array}{l}\text { Tilito Mambuca } \\
\text { Tilito Rafard }\end{array}$ \\
\hline & & & Fm. Capivari & \\
\hline & & & Fm. Itu & $\begin{array}{l}\text { Tilito Elias Fausto } \\
\text { Tilito Salto }\end{array}$ \\
\hline
\end{tabular}

C1assificação estratigrä́ica do Grupo Tubarão

Os subgrupos Itararē e Guatá apresentam-se, em aspectos gerais, como duas unidades distintas, embora relacionadas entre si, ao que parece, pela sequência deposicional. Bigarella et Salamuni (1967), sugerem uma discordância entre esses dois subgrupos, apresentando argumentos de ordem paleogeográfica. Northfleet et al. (1969), interpretam esse limite como coñcordante, sendo a base do Subgrupo Guatá, considerado como localizada na base da primeira camada de arenito (da Formação Rio Bonito) que aparece acima do ūltimo corpo de diamictito da Formação Itararé.

No presence trabalho adotamos esse critērio para estabelecer tal limite, na parte sul do Estado. Entre outros motivos, citamos o fato de que tal critério se mos trou muito prático durante os trabalhos de campo. Vasta área 


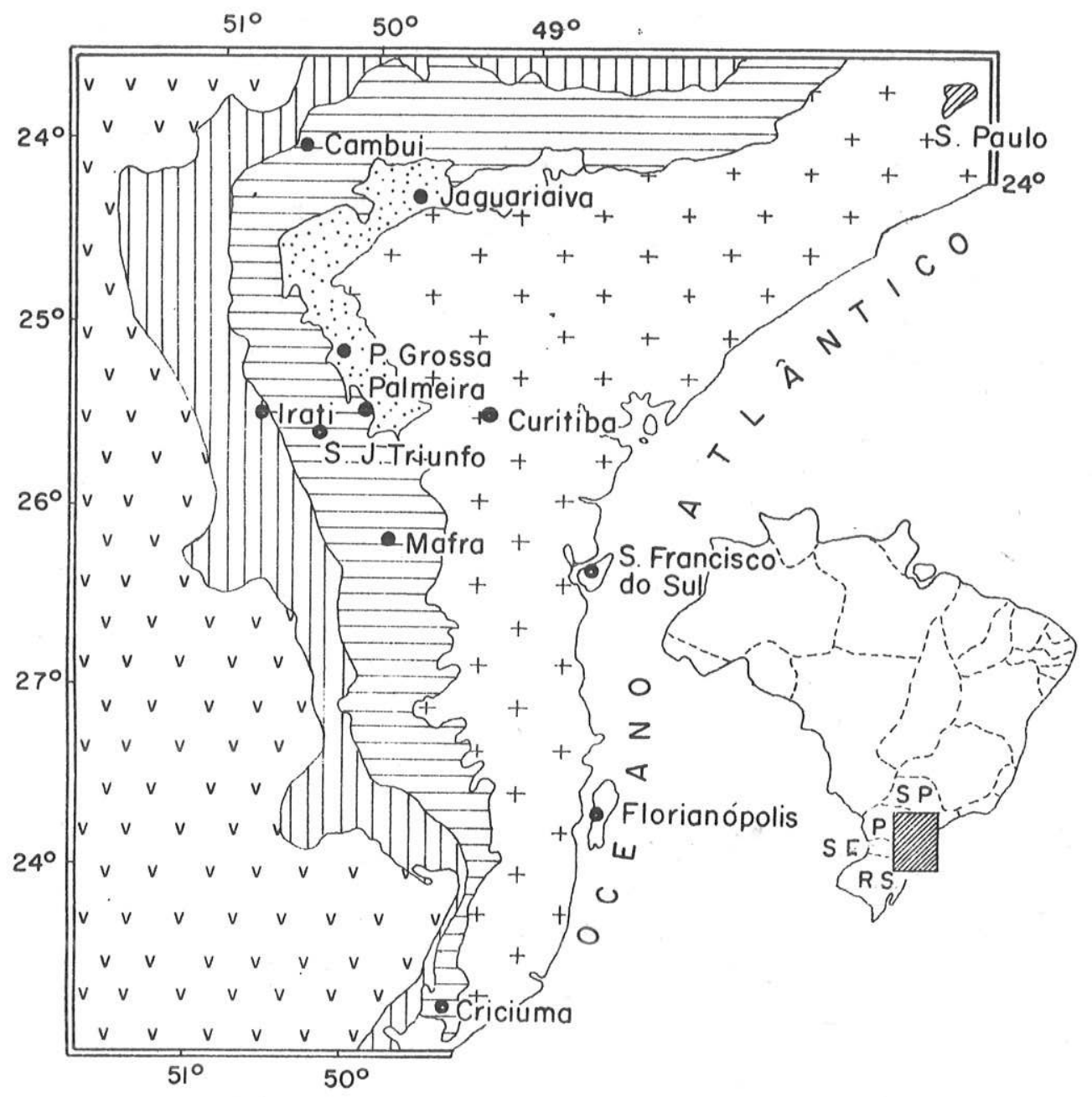

vvvv v Principalmente basaltos e Formação Botocatu, (Cretáceo)

[I][T]T] Grupo Passa Dois (Permiano)

E- G Grupo Tubarão (Carbonifero e Permiano)

$\because \because$ Grupo Campos Gerais (Devoniano)

$\mathrm{L}_{+}^{+}+{ }_{+}^{+}$Principalmente Pré - cambriano

Fig. 1- Esboço geológico mostrando a situação da faixa aflorante do Grupo Tubarão em relação as camadas supra e subjacentes, (nos estados de Santa Catarina, Paraná e sul de Săo Paulo). 
da faixa aflorante do Subgrupo Itararé e Formação Rio Bonito, foi percorrida com o objetivo de realizar coletas e localizar novas ocorrências fossiliferas. No transcorrer desse trabalho, verificou-se que o arenito da base dessa última formação, é facilmente reconhecido por seu aspecto. Embora o Subgrupo Itararé seja também constituỉdo por numerosos leitos areníticos, é sempre fácil distinguí-los daqueles da Formação Rio Bo nito.

Na parte noroeste do Paraná, consideramos como base da Formação Rio Bonito, o conglomerado infraposto a esse arenito, e sobreposto discordantemente ao ủltimo diamictito (Fig. 7). Esse critērio se aplica de forma mais adequada, naquela região, principalmente, por concordar melhor com a histöria sedimentar. De fato, geneticamente aquele conglomerado pode ser considerado como residual, ou seja, corresponderia a um tempo no qual teria havido erosão do diamictito infraposto, com a sucessiva concentração dos clastos maiores inclusos nessa rocha. Nesse caso, o ciclo deposicionàl da uni dade superior, ter-se-ia iniciado com o conglomerado, pois da maneira como se apresenta indicaria seu aspecto no fim da fase erosiva. Leinz (1940), constitui o primeiro trabalho a in terpretar tais conglomerados, encontrados naquela área, como conglomerado residual.

No sul do Estado não encontramos esse conglomerado, ou evidências de discordância entre as duas formações. Na região de Teixeira Soares e São João do Triunfo, em outras āreas mais ao norte, até proximidades de Telêmaco Borba, encontra-se, abaixo da Formação Rio Bonito, o Folhelho Pas sinho. Esse folhelho contēm uma fáunula marinha, geralmente com exemplares de pequeno tamanho (Lange 1952). Tem sido con siderado como leito fossiliffero superior do Subgrupo Itararé 
no Paranā, tanto na área aflorante, como em subsuperfície.

A complicada composição litológica do Subgrupo Itararé, compreende depósitos que têm sido interpretados como evidências de atividade glacial. E provável que ape nas poucos, ou nenhum dos diamictitos correspondam a verdade ros tilitos. No entanto, dado ao conjunto de aspectos, é pos sível que, pelo menos alguns desses diamictitos, representem realmente material retrabalhado, porēm indiretamente, tenham relação com a atividade glacial. Várias outras possíveis evi dências de atividade glacial ou periglacial têm sido noticiadas. Rocha Campos (1967), apresenta uma discussão sobre esse problema.

Um clima rigoroso na época da deposição das camadas da Formação Itararé, estaria de acordo com o fato de serem extremamente raros os fösseis vegetais nas mesmas. Essa pobreza da paleoflora é constatada mesmo nas numerosas litologias que aparentemente se constituiriam em matrizes ade quadas à preservação de impressões. Rigby (1970) inclui todas as ocorrências de tafoflōrulas, no Estado do Paranā, no Subgrupo Itararē, o que deve ser retificado para Formação Rio Bo nito (Subgrupo Guatā).

\section{FORMAÇÃO RIO BONITO}

A Formação Rio Bonito, na qual foram coletados os fósseis aqui tratados, constitui a parte inferior do Subgrupo Guatá, o qual corresponderia à fase "post-glacial" do Grupo Tubarão. o limite inferior dessa formação já foi discutido acima. O contato superior com a base da Formação Pa- 
lermo, se faz concordantemente. Northfleet et al. (1969) colocam o limite superior dessa formação no topo do ültimo corpo arenitico, acima do qual aparecem os siltitos cinzas, ou cinza-esverdeados, da Formação Palermo.

Os mapas de isópacas da Formação Rio Bonito (Northfleet, 1969) mostram que as maiores espessuras são atingidas na parte noroeste da Bacia do Paranā, diminuindo con sideravelmente em direção às áreas aflorantes a leste. A faí xa aflorante contorna a parte oeste do arco de Ponta Grossa e é cortada por numerosos diques de diabásio, geralmente intromissos em planos de falhas.

Os arenitos que compõe grande parte dessa formação, frequentemente exibem uma estratificação cruzada ; O ambiente de deposição dos mesmos parece corresponder a extensos depósitos deltaicos (Rocha Campos, 1967 e 1972). Lembramos que os leitos de carvão ocorrem intercalados nesises are nitos. Algumas observações sobre o ambiente de deposição das camadas hulheỉferas da Formação Rio Bonito no Paranā, são feî tas no presente trabalho. Tais observações concordam, ou pelo menos, não se chocam, com a hipótese que admite o ambiente deltaico acima referido.

A idade dessa formação, conforme Rocha Cam pos' (1967, 1970 e 1972), indicada atravēs de fōsseis marinhos (Ariocrassatella, Myonia, Heteropecten, etc.) na porção média da mesma, no Estado de Santa Catarina, seria Permiano Inferior. Daemon et Quadros (1969) sugerem, com base palinológica, idade permianā superior.

A paleoflora aqui estudada, sugere, para a parte basal da Formação Rio Bonito, no Paranā, uma idade não mais antiga que o Permiano, provavelmente Permiano Inferior. 


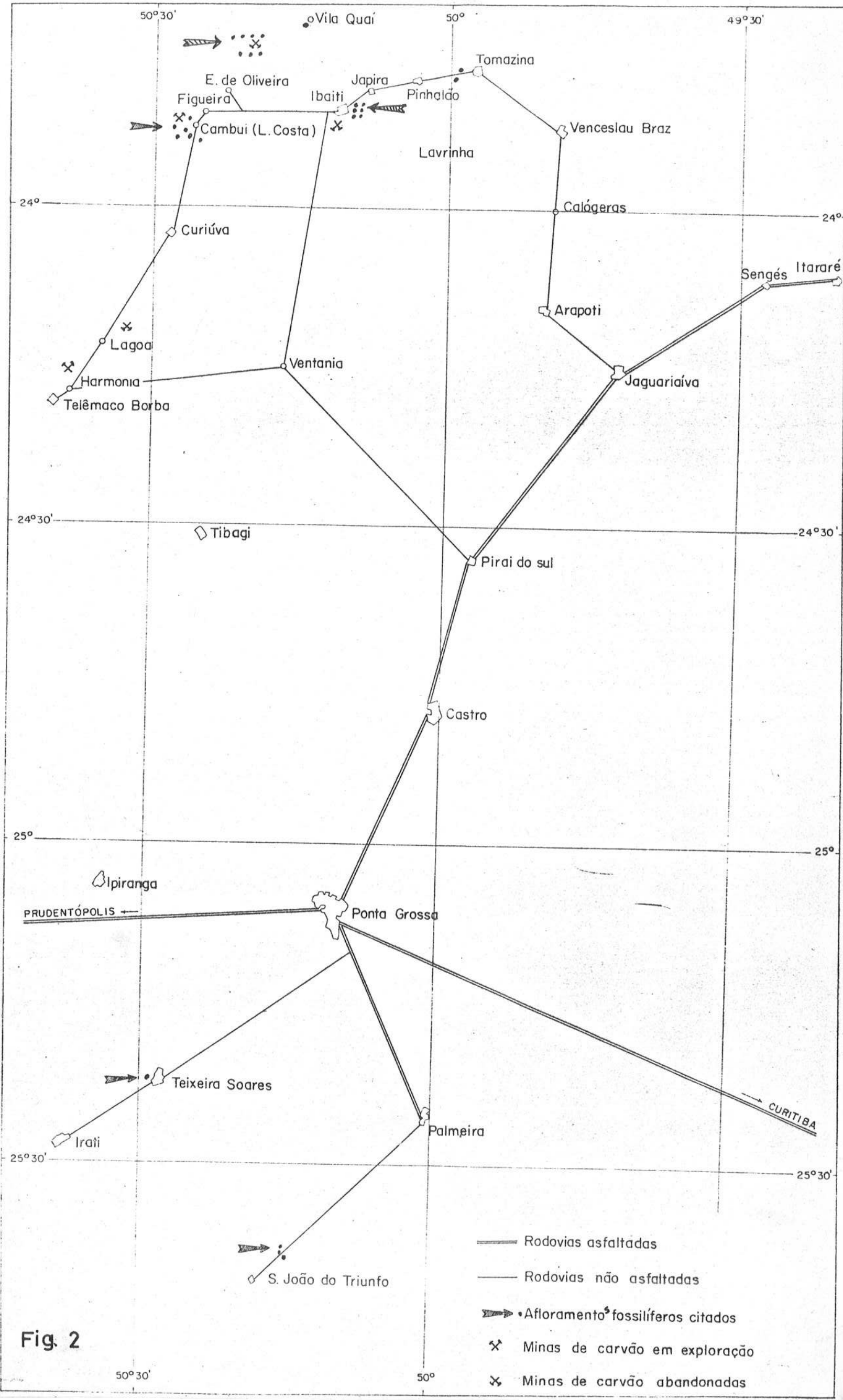

Fig. 2 - LOCALIZAÇÃO E ACESSO AOS AFLORAMENTOS CITADOS. 


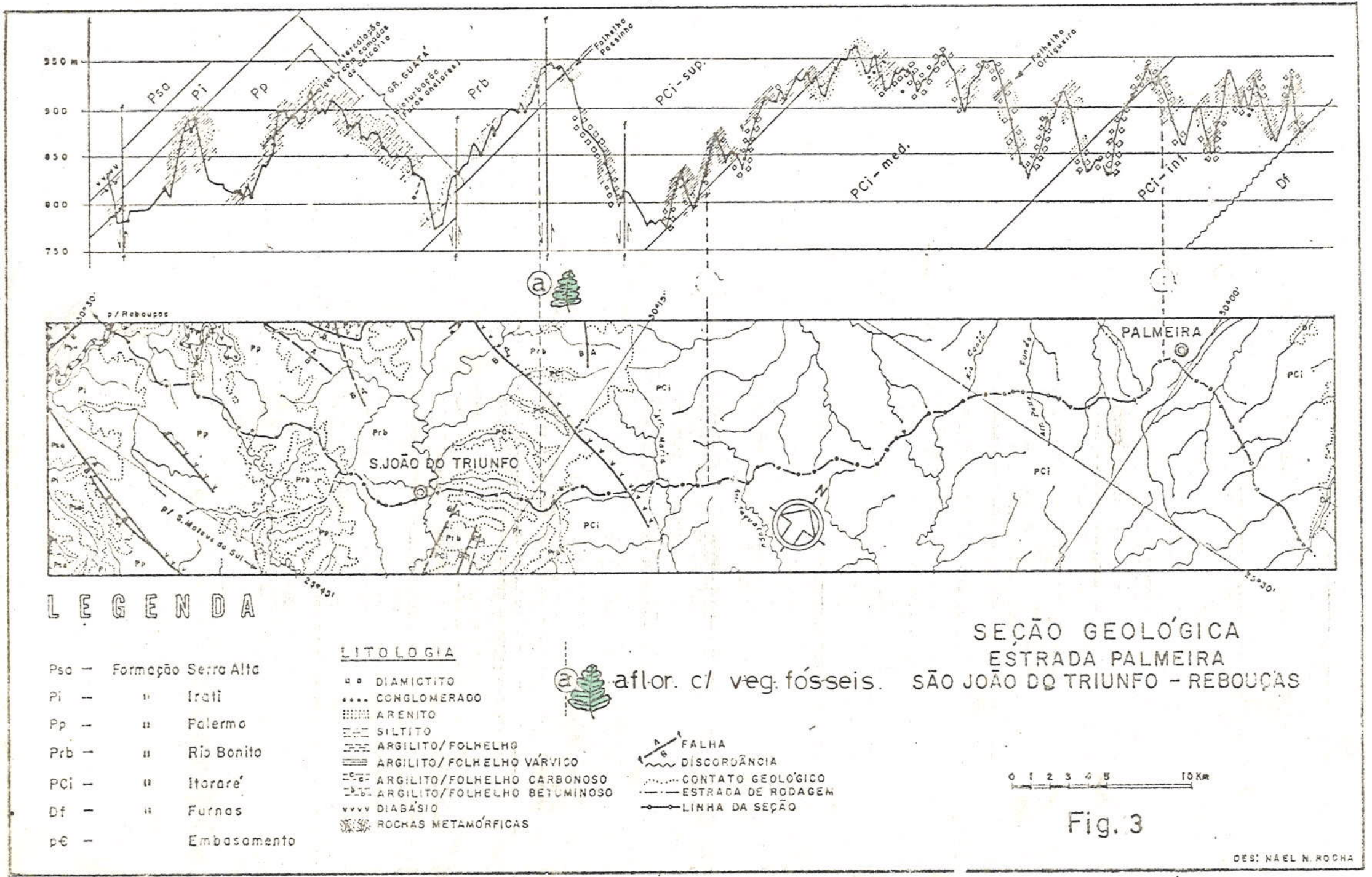




\section{VI - AFLORAMENTOS ESTUDADOS}

Na fase de trabalhos de campo, foi percorrida extensa área cobrindo grande parte da faixa aflorante da Formação Rio Bonito, e parcialmente tambẻm, do Subgrupo Itararē. Enquanto este subgrupo revelou-se muito pobre em fósseis vegetais, com apenas uma ocorrência próxima a Tomazina (Fig. 2), a Formação Rio Bonito mostrou-se mais promissora. Há um grande número de afloramentos dessa formação, nos quais, muito embora não tenhamos obtido bons resultados em trabalhos preliminares de coleta, se afiguram como promissores. Há algumas outras äreas que necessitam ainda ser percorridas.

As ocorrências de fósseis vegetais, que já de longa data, são conhecidas, bem como aquelas as quais se relacionam nossas coleções são assim denominadas no presente traba1ho:

1) São João do Triunfo, 2) Teixeira Soares,

3) Cambuí, 4) Rio Carvãozinho, e 5) Ibaiti

1 - Localidade SÃO JOÃO DO TRIUNFO

Tivemos conhecimento dessa ocorrência atravēs de Medeiros (1971 p. 20) onde se lê:

"Arenitos basais da Formą̧̃o Rio Bonito.(.......) Ocorre uma camada de $3 m$ de argilito cinza claro a cinza escuro, carbonoso, contendo abundância de res tos de plantas e um nivel de carvão."

Os afloramentos situam-se na estrada que liga Palmeira a são João do Triunfo, oito quilômetros antes de atin- 
Fig. 4 - Perfis colunares construídos a partir de dados coletados em dois canais separados lateralmente pela distância de 10 metros, no afloramento apresentado na figura 28, da estampa 6. (São João do Triunfo). Observa-se uma variação relativamente grande na espessura das camadas, quando se confrontam essas duas colunas. Outros perfis foram tambëm elaborados nessa ärea. A situação pode sex generalizada da forma como se apresenta nas figuras 5 e 6 . 


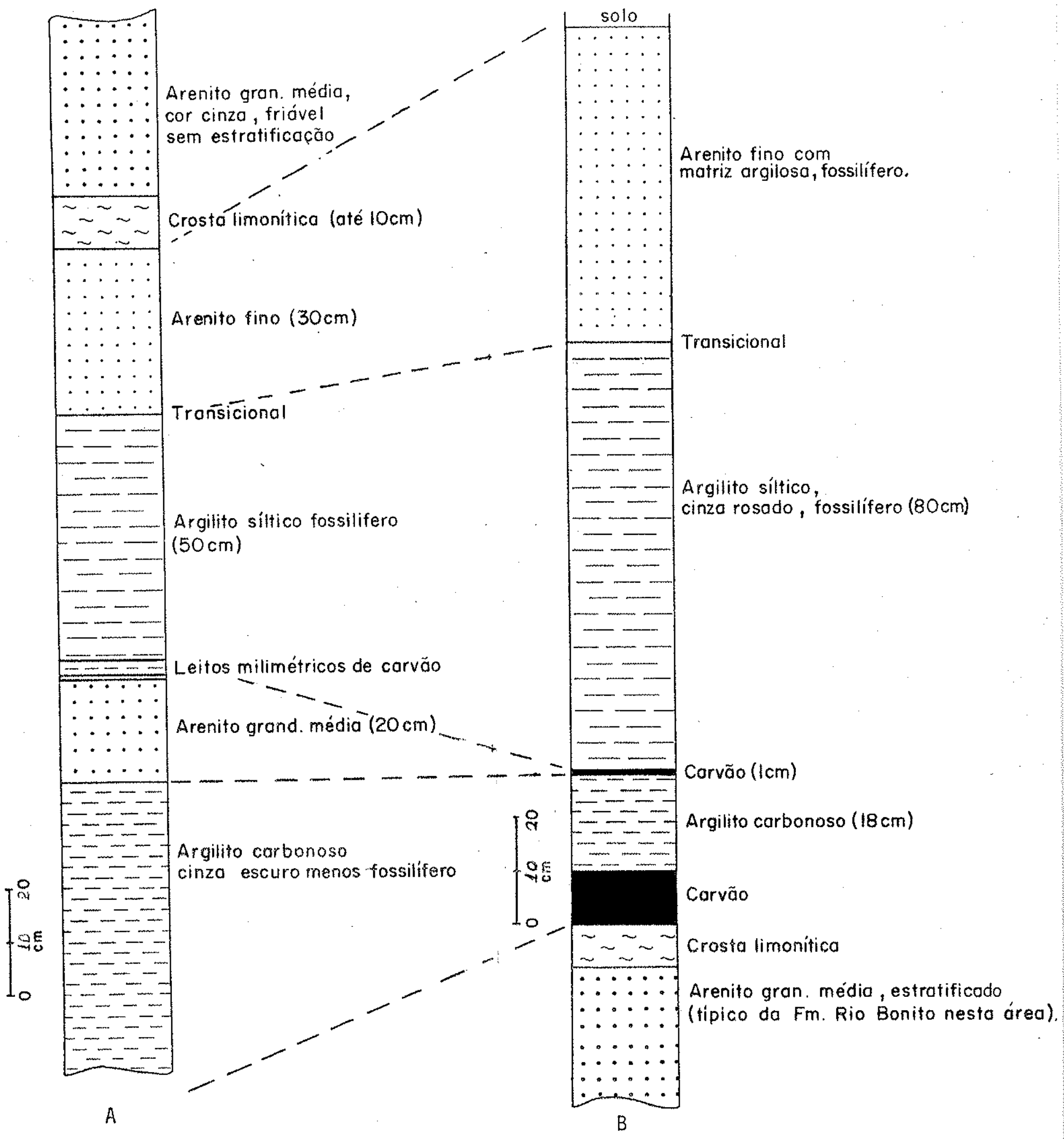

Fig. 4 -VIDE LEGENDA NA PAGINA ANTERIOR 
Fig. 5 - Representação da média da composição granulométrica, baseada em 16 anälises; As amostras foram retiradas dos niveis $A, B, C$ e $D$, conforme fig. 6 .

Fig. 6 - Perfil colunar simplificado, representando a situaÇão geral na parte basal da Formação Rio Bonito, na região de São João do Triunfo. o arenito que predomina naquela ărea, apresenta-se intercalado pela camada fossilifera. Essa basicamente apresenta, na parte inferior, uma fina camada de carvão que passa a argilito carbonoso. Este passa a argilito siltico (que contëm os fösseis melhor conservados). Na parte superior há um enriquecimento de clastos maiores.

A espessura do arenito situado na base dessa camada, e acima do Folhelho Passinho, torna-se dificil de ser estabelecida em afloramento. Isso se deve à exis tência de uma falha cortando esses arenitos (Ver fig. 3). 


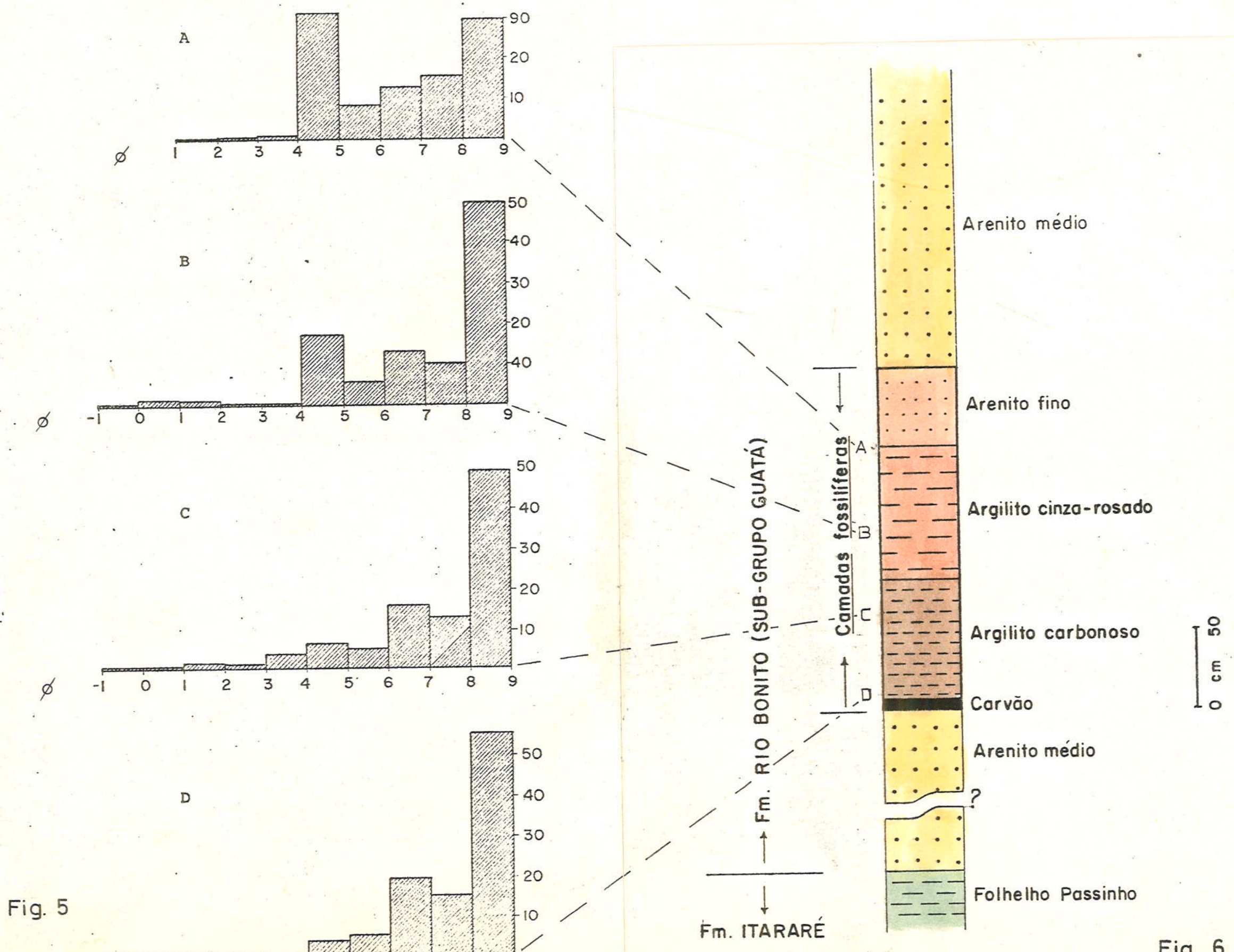

Fig. 6 
gir essa ültima cidade (Fig. 2 e 3). A camada fossilífera está exposta nos cortes, de ambas as maxgens dessa estrada, bem como no corte da estrada antiga, que conflue com aquela, naquele trem cho. A melhor exposição $\vec{e}$ a situada ao lado esquerdo da estrada nova (orientação conforme sentido Palmeira - S. J. Triunfo), vis ta na fig. 28 da estampa 6.

Realizamos duas viagens de coletas a esse aflo ramento, o qual revelou-se o mais importante dentro das conhecidas no Estado do Paranä. Essas coletas foram realizadas em dife rentes pontos dessa exposição, e principalmente no corte acima citado (est. 6, fig. 28). As amostras foram retiradas ao longo de cinco canais verticais, espaçados lateralmente de 5 metros.

A Iitologia observada em dois desses canais, estā representada nos perfis colunares da fig. $4 . \quad$ Sumariando - conjunto de informações litológicas e da sua sequência no local, vexificada em diferentes partes daquelas exposições, podemos construir o perfil colunar apresentado na fig. 6. Vemos por tanto, que a camada fossilifexa estä intercalada nos arenitos da base da Formação Rio Bonito. A camada de carvão ê seguida por argilitos escuros, que gradativamente passam a um argilito cinzarosado na parte mëdia. Esse passa a argilito silltico e finalmente a siltito arenoso, atë arenito muito fino, no topo da cama da fossilifera (fig. 5 e 6 ).

\section{2 - Localidade TEIXEIRA SOARES}

Em T. Soares afloram os sedimentos da base da Formação Rio Bonito, formados pxincipalmente por arenitos, tendo uma camada de carvão neles intercalada. Geralmente associada a essa camada de carvão, ocorrem argilitos carbonosos, que contêm 
fösseis vegetais, e daí procede parte do material estudado por Oliveira (1927). A principal exposição desse argilito encontrase a oeste daquela cidade no vale do cörrego Minhocão. Esse argilito corresponde ao Folhelho Minhocão de Almeida (1945) e está situado acima da camada de carvão. Essa sequência è comparável àquela da figura 6 , da região de S. J. do Triunfo. De fato, no cörrego Baitaca, a leste de T. Soares aflora o Folhelho Passinho, imediatamente abaixo dos arenitos da Formação Rio Bonito. Esses, por sua vez, como vimos acima, estão intercalados por camadas de argilito e carvão.

As coletas aqui foram prejudicadas pela depo"sição de toneladas de terra por sobre a parte aflorante do argilito fossiliffero, no cōrrego Minhocão. Essa deposição fora efetuada devido a obras de terraplanagem no flanco leste daquele va le.

Retiramos desse afloramento uma pequena quanti dade de fösseis, geralmente mal conservados, predominando o gêne ro Paracalamites.

\section{3 - Localidade CAMBUI}

Essa localidade foi citada por oliveira (1927, p. 73) como Fazenda do Cambuhy. Os afloramentos dessa ārea, conhecidos na literatura, são os situados nos afluentes da margem esquerda e direita do Rio das pedras nessa região. Atualmente, a Companhia Carbonifera do Cambuí, que explora o carvão naquela ärea, abriu um grande nümero de galerias. o acesso a essas se faz por um poço, tendo o mais profundo deles, cerca de $120 \mathrm{~m}$ de profundidade, onde se atinge a camada de carvão ("Campo da Brasi 
leira", est. 6, fig. 29). A capa desse carvão é formada por um siltito argiloso, carbonoso e com alto teor de pirita. Nesse sil tito ocorrem plantas fósseis e grande parte do material que cole tamos na região nordeste do parană, corresponde a amostras da ca pa desse carvão. As galerias que forneceram maiox quantidade de material, são as do campo 115, da Companhia acima citada, onde - carvão está a $36 \mathrm{~m}$ abaiło da superfície.

O campo 5 do distrito hulheifero do Cambui (est. 6, fig. 30) foi visitado dias antes do desabamento que ali. ocorreu. Hoje estā completamente inacessível.

\section{4 - Localidade RTO CARVÃOZINHO}

Atualmente o acesso a essa localidade $\vec{e}$ dificil devido à densa vegetação, que no local tambēm encobre totalmente os afloramentos. Não hã mais sequex uma galeria aberta. pode-se atingir as imediações do local por uma pequena estrada que se deriva à direita da estrada Ibaiti-Figueira, cerca de 15 $\mathrm{km}$ da primeira. Segue-se atë atingir a estrada de fexxo, hoje abandonada. Descendo-se em seguida por um atalho que se inicia atrās da estação, toma-se rumo oeste, em direção à parte baixa do vale, senđo necessärio abrir uma picada, atë atingix o rio car vãozinho.

A camada de carvão outrora explorada è cortada por aquele vale e aflorava em ambos os flancos. o principal tra balho sobre essa bacia de carvão é o de Leinz (1940). Vários ou tros se referem a essas camadas entre os quais citamos os de Dutra (1940), Paiva (1940) e Decourt (1940).

Dessa localidade procedem alguns vegetais fós seis estudados por Oliveira (1927) e Read (1941). 


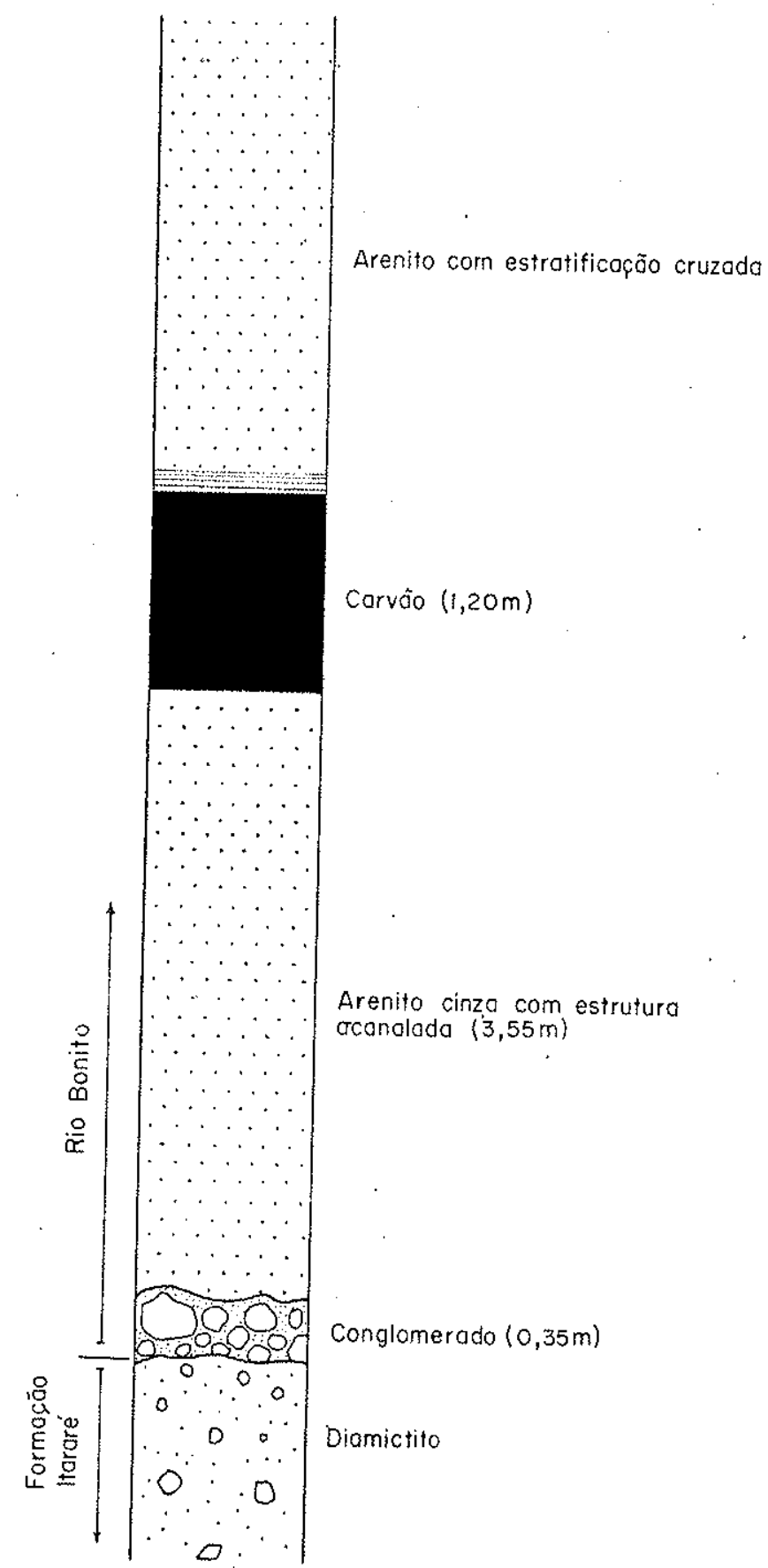

Fig. 7-Aspecto do contato entre as Formaçes Rio Bonito e ita. raré e a sequência do parte basal daquela, observada no Vale do Ribeirơo do Mino Velho (Ibaiti) 


\section{5 - Localidade IBAITI}

Ibaiti corresponde à localidade conhecida na literatura como "Barra Bonita", e o "ribeirão da Barra Bonita" , onde aflora a camada de carvão, ë conhecido hoje por Ribeirão da Mina Velha. Nos flancos bastante verticais do vale desse ribeiräo, situado a oeste de Ibaiti, pode-se perceber com muita facilidade a sequência basal da Formação Rio Bonito, bem como o topo do Subgrupo Itararé. Desse local, construímos o perfil colunar da fig: 7. Alguns fósseis estudados por Read (1941) procedem das minas exploradas nesse local há mais de 20 anos atrás. Um bom estudo sobre o carvão de Ibaiti (Barra Bonita) é feito em Leinz (1940).

\section{S I S T E M A T I CA}

A seguir é apresentado um estudo sobre os grupos de vegetais representados na paleoflora da Formação Rio Bonito no Estado do Paraná.

E dada maior ênfase aos grupos que podem ser jul gados importantes, levando-se em consideração os seguintes crité rios: 1) Formas importantes para a correlação e idade; 2) Formas que devido ao seu grau de conservação e abundância, permitem um melhor estudo; 3) Formas novas e 4) formas de importância sistemātica.

Os grandes grupos tratados a seguir são: Lycophyta, Sphenophyta, Filicophyta, Pteridospermaphyta e Coniferophyta. (Adotando a nomenclatura usada no plano do Traité de Palēobotanique de Boureau). 


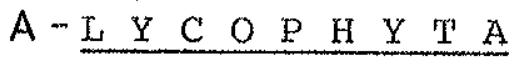

A quantidade de impressôes de licôfitas é rela tivamente grande nos sedimentos da capa de carvão da região de Cam bui. Apesar dessa abundância, é muito pequeno o nümero de exempla res que apresentam boas condições para estudo. Os principais espëcimes, melhor conservados estão figurados na estampa 1, fig. 5.

Esses espëcimes apresentammse com alguns detaIhes interessantes, embora sejam praticamente idênticos a algumas formas descritas como Lycopodiopsis pedroanus (Carruthers) Edwards. o exemplar figurado na fig. 2, est. 1, pode não corresponder a es sa forma. Outros exemplares parecem representar formas novas.

Acreditamos que è absolutamente necessária uma profunda revisão no material de licöfitas brasileiras. Esśa revi são não deverá prescindir de um confronto direto com as formas do hemisfério norte. Por esse motivo excluimos do presente trabalho, - estudo dessas formas que passaram a constituix um projeto de pesquisa à parte. Com relação ao andamento desse projeto sobre o material de licófitas, podemos adiantar que a comparação que realizamos com os espécimes do Museo de La plata (La plata - Argenti na) serviu para demonstrar que idêntica revisão se afigura como necessāria tambēm, daquele Material. 


$$
\begin{gathered}
\text { B-L SPHENOPHYTA } \\
\text { (= Aenson, } 1957 \\
\text { Arthrophyta Berry, } 1915 \text { e Calamophyta Smith, 1955) }
\end{gathered}
$$

Duas das quatro ordens de Sphenophyta estão representadas na flora aqui estudada: Sphenophyllales e Equisetales. A primeira compreende três famílias sendo que, apenas uma delas, Sphenophyllaceae, está aqui representada pelo gênero Sphenophyllum. A segunda está representada por Annularia, que se constitui em um gênero de órgãos de Equisetales incerta sedis e paracalamites, gênero baseado em moldes medula res de caules.

Gênero SPHENOPHYLLUM Koenig, 1825

No Estado do Paranä, Sphenophyllum osorre em camadas, cuja idade provävel ê permiana inferior. Sphenophyl lum aparece no registro geológico em camadas devonianas. Atinge seu apogeu no periodo Carbonífero, sendo que, no permiano se torna já mais raro. Esses vegetais não atjngiram grande porte, sendo geralmente frägeis. Segundo värios autores, talvez teriam tido hábito semi-aquático.

E interessante o fato de que, todos os exemplares aqui estudados, ocorrem na região de Cambuĩ. Nos afloramentos aỉ estudados, os diferentes fósseis encontrados geraI mente não tem preservados, os detalhes mais delicados. Os tron cos que aî ocorrem estão frequentemente decorticados. Apesar disso, alguns exemplares de esfenofjläceas apresentam-se relativamente bem conservados. Os verticilos foliares sem rupturas, mesmo no bordo externo das folhas, paxte essa, aparentemente mui to frägil nesses vegetais. Esse fato sugere que não tenha ha- 
vido praticamente nenhum transporte. E provävel portanto, que tenham vivido no pröprio ambiente, talvez aluvional-palustre, onde se depositaram os sedimentos da matriz que os contêm.

A pequena anisofilia apresentada pelos exem plaxes estudados, constitui um aspecto que poderä vir a ter grande importância na compreensão das relações filogenēticas en tre as formas isofilicas e as que tem a anisofilia bem acentua da, como a forma Trizygia. Essas são mais frequentes no Permi ano, e mais caracteristicas das provincias do Gondwana e Cathaysia.

S. brasiliensis n. sp. (descrita adiante), pode representar uma forma intermediēria, quanto à morfologia das folhas de cada verticilo, entre os gêneros Sphenophyllum e Trizygia. Lembramos que Maheswari (1967, p. 283-287) demonstrou a existência de difexenças que justjficam a separação dos dois gêneros. Essas diferenças sexiam, alēm das de ordem paleo geogräfica, principalmente quanto às caracteristicas de epider me. Segundo Maheswari (op. cit.), pelo menos a espëcie Tri zygia speciosa Royle, não pode ser considerada dentro do gênero Annularia.

Boureau (1964, p. 5l), considerou Trizygia em sinomia com Sphenophyllum. Esse autor admitiu como possivel a coexistência de conjuntos foliares, numa mesma planta, com diferentes graus intermediāxios entre os dois gêneros. Ao nosso ver, mesmo verificando-se tal coexistência, não estaria eliminada a possibilidade de existirem formas distintas, carac terizando cada um dos citados gêneros, principalmente em áreas geográficas distintas. A espëcie Annularia readi tem, sem düvi da, mais afinjdade com o gênero Annularia que com Trizygia, $x \underline{a}$ zão pela qual foi incluída naquele gênero, porēm a posiçäo que 
ela ocupa entre esses dois grupos, pelo menos, sob os aspectos morfológicos, nos parece clara.

Uma ünica espëcie desse gênero fol reconheci da na Formação Rio Bonito no Estado do Paranā: $\underline{\text { s. brasiliensis }}$ n. sp.

\section{$\underset{*}{*} \underset{*}{*} \stackrel{*}{*} \underset{*}{*}$}

\section{SPHENOPHYTA}

Sphenophyllum brasiliensis

C 86

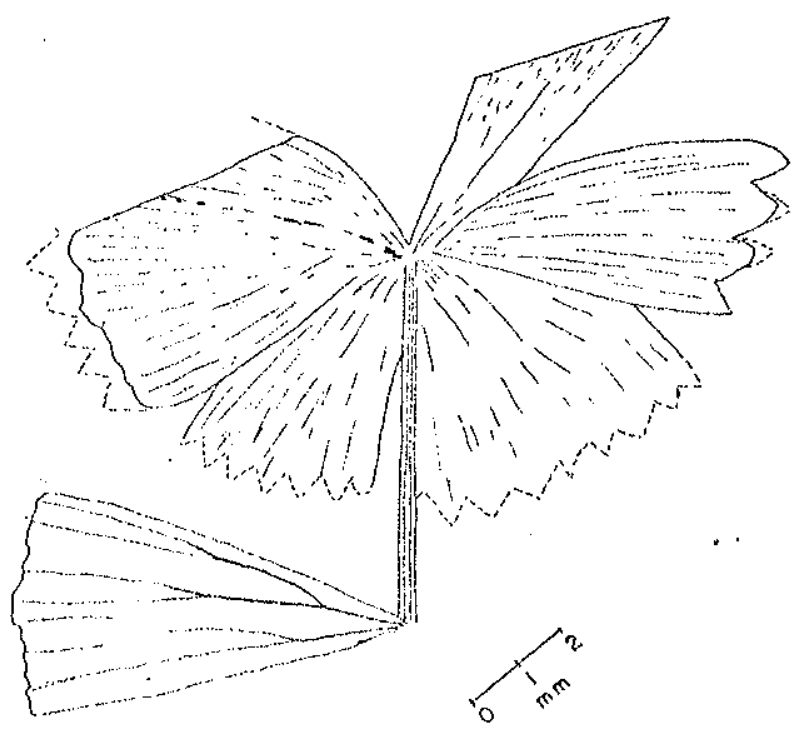

Fig. 8

Fig. 8 - Sphenophyllum brasiliensis. Desenho reproduzindo o exemplar $\mathrm{C86}$ (Holótipo) que aparece na fig. 17 da est. 3. Detalhes de nervação e morfologia do bordo foliar são melhor ubservados em outros exemplares. Este porëm torna-se interessante por apresentar as folhas 1 i gadas ao caule, que por sua vez exibe dois nós. 
Sphenophyllum brasiliensis n. sp.

Est. 3 Fig. 16,17 e 18

Fig. 8 (päg, anterior)

\begin{abstract}
Sphenophylum oblongifolium - Lundqvist, 1919, p. 24-25, Taf. 2, Fig. 18-24; Read, 1941, p. 90-92, Est. 6, Fig. 1, 2; Dolianiti, E., 1948, Est. 6, Fig. 1
\end{abstract}

Sphenophyllum cf. oblongifolium - Rigby, 1970, p. 576

a. Holötipo - Campo Carbonifero de Cambuí, Mu nicipio de Curiuva, Estado do Paxanä, leg. ROsler, ne C86.

b. Diagnose - Plantas articuladas com vertici lo foliar com diâmetro entre $12,5 \mathrm{~mm}$ e $19 \mathrm{~mm}$. 6 folhas com bordos laterais Ilgeiramente convexos, com malor largura atingida entre a porção mediana e distal. Forma das folhas pouco variävel num mesmo vexticilo, sendo que as de menor tamanho, situadas junto ao caule, têm comprimento menor em relação às demais, diferença esta que ë inferior a 15\%. Bordo externo com dentes $e$ incisões com profundidade em torno de $1 \mathrm{~mm}$, sem muita variação. Ner vação com 3 (ou mais?) dicotomias sucessivas com intervalos em torno de $2 \mathrm{~mm}$.

c. Descrição - Plantas articuladas com folhas dispostas nos nōs dos caules formando verticilos com seis folhas, às vezes 5 ou quatro, nesse caso por perda de uma ou duas. O ver tictlo foliar tem o diâmetro compreendido entre $12,5 \mathrm{~mm}$ e $19 \mathrm{~mm}$. As folhas são subtriangulares com os bordos laterais suavemente convexos, sendo que a maior largura é atingida entre a porção mediana e a distal. O bordo externo apresenta dentes com extremi dades mais ou menos agudas, conforme o exemplar C33b (Fig. 16, , est. 3). As incisões entre os dentes se aprofundam geralmente $1 \mathrm{~mm}$ não tendo sido observado incisão mais profunda na porção mediana do bordo externo. O tamanho das folhas varia de um exemplar para - outro, mas é pequena a sua variação no mesmo verticilo (menorque 158, sendo que as menores estão situadas junto ao caule. 0 comprimento das folhas varia entre $6 \mathrm{~mm}$ e $9 \mathrm{~mm}$ e a largura atinge de $2,5 \mathrm{~mm}$ a $6,0 \mathrm{~mm}$. Ao longo do comprimento do limbo podem ser percebidos 
três niveis de dicotomias, os dois primeiros mais evidentes. Uma só nervura penetra na base foliar, sendo que a primeira dicotomia situa-se de $1,5 \mathrm{~mm}$ a $2,0 \mathrm{~mm}$ da insersão foliar. A segunda dicotomia estā situada de $1,4 \mathrm{~mm}$ a $2,0 \mathrm{~mm}$ da primeira. Em alguns casos, una das nervuras surgidas da primeira dicotomia aparentemente não se dicotomiza mais, seguindo atẻ o bordo externo. A terceira dicotomia è menos facilmente observável en nosso mate rial, no qual os detalines mais delicados não estão bem conservados, o que acontece com a impressão das nervuras entre a porção mediana e distal do limoo. Cada dente do bordo externo recebe uma nervura, fato perceptivel em dois exemplares sendo que em ou tros os detalhes do bordo externo não estão bem visiveis. Três exemplares apresentam as folhas presas ao fragmento de caule. 0 comprimento do entrenó em dois deles é de $9 \mathrm{~mm}$ e noutro é de 7,5 $\mathrm{mm}$. A largura do caule ë de 1 a $2 \mathrm{~mm}$. Existem dēbeis estrias longitudinais, en nümero não confirmado, porém superior a três.

d) Discussão - Essa nova espëcie apresenta em seu aspecto geral, grande semelhança com $\mathrm{Sph}$. oblongifolium (Ger mar \& Kaulfuss) Unger, 1850 (in Boureau, 1964, p. 76) (= Trizygia oblongifolia (Germ. \& Kaulf.) sensu Asama - 1970), com Sgh. angustifolium (Germar, 1845) Goeppert, 1848 (in Boureau, op. cit. p. 54), e ainda com Sph. cuneifolium (Germax et Kaulfuss, 1831) Unger, 1850 (in Boureau, op. cit., p. 59).

Em relação a Sph. oblongifolium observam-se algumas diferenças importantes em nowso material. Nesse, verifi camse que, entre os três pares de folhas do vexticilo foliar, as diferenças de tamanho, forma e disposição, é pequena. o comprimento das folhas menores $e$ apenas 15\%, ou menos, menor que o das folhas maiores. Isto confere ao verticizo relativa homogeneidade quanto ao tamanho das suas folhas.

Jâ em Sph. oblongifolium esta diferença è. mar cante, uma vez que, o par menor, atinge, em mëdia, apenas a meta de do comprimento do par maior. Alëm disso a disposição das fom lhas ë claramente de Trizygia.

Este aspecto é muito importante, porque mostra a existência de uma diferença fundamental sob o ponto de vis ta taxionômico. Ao mesmo tempo, confirma a existência de formas intermediārias entre as do gênero Sphenophyllum e Trizygia (ver päg. 28 ). Deve-se aquj lembrar que o aspecto apontado acjma poderia não ser decisivo, visto que, segundo Boureau (1964, p.54), Sph. oblongifolium possuixia ramos com folhas desiguais, acompa- 
nhadas de outros corn folhas homogêneas. No caso do material de Cambûi, que se apresenta fragmentärlo e os ramos com folhas estão representados por fragmentos compreendendo no máximo tres en trenōs, è evidentemente difícil confirmar a existência ou.não da citada anisofilia.

Consideramos porëm, dois aspectos, que ao nos so ver, distanciam decisivamente a possibilidade de serem esses nossos exemplares sirnples variações dentro das formas compreendi das como Sph. oblongifolium, ou ainda, serem variações dentro do mesmo espëcime: Em primeiro lugar os diferentes exemplares, em distintas amostras estudadas, provavelmente representam diferentes individuos e distintas partes do vegetal. Apesar disso veri ficamos que as relações métricas em nosso material são bastante constantes, quando comparadas umas as outras.

Em segundo lugar, fato ainda mais significati vo, verificou-se que o padrão de nervação apresenta impressionante constância em nossos exemplares. Jä em Sphenophyllum oblongifolium (in Boureau 1964, p. 76) não hä essa constância. Quan to as nervuras, o principal aspecto diferencial entre as duas es pëcies ẽ a posição das zonas de dicotomias, muito constantes de um exemplax para outro. Essas zonas são tambêm relativameñte, equidistantes (Fig. 8 ), o que igualmente näo ocorre em $\underline{\text { ph }}$. oblongifolium.

Pox ültimo, sph. oblongifoljum apresenta uma incisão mais profunda entre os dois dentes medianos do bordo externo das folhas. Em nosso material, isso não se constatou. Ao que parece, as incisões são todas aproximadamente de rnesma grandeza. Lembramos porém que tanto Lundquist (1919) como Read (1941), descreveram material procedente da mesma região (embora não dos mesmos afloramentos), e assinalam a existência daquela incisão no bordo externo das folhas. Considerando que esse bordo externo, è a porção mais frâgil do limbo foliar, e ruase sempre os seus detalhes não são tão claramente visíveis como no restante dele, admitimos que tanto é possivel deixax de perceber, quanto vexificar a existência aparente da citada incisão. Aliás, è in teressante notar, que a descrição de Lundqvist (op. cit.) é real mente mais concordante con a de Sph. oblongifolium, que a descxição feita através das observaçöes de nossos espécimes, os quais acreditamos não pertencerem àquela espēcie. 
Em relação a Sph. anqustifolium (in Boureau, 1964, p. 54) existe alguna semelhança corn a nova espëcie aqui des crita. Porén esta possui as follnás bern maiores que aquela e não tern, ao que pudemos observar, a tendência de se dividir bi fidamente, e possui os dentes menos agudos. Alërn do mais, hä diferenças, quanto às dimensões dos entrenös.

Em relação a Sph. cuneifolium (in Boureau, 1964 , p. 59, fig. 32) a nova espēcie apresenta tambēm alguma semelhança, principalnente quanto à forma geral. Essa semelhança tambēm foi constatada quanto ao bordo externo das folhas. Difere fundamentalmente, porém, quanto à nervação, una vez que, no material estudado a nervura que penetra na base do limbo foliar se dicotoniza, formando duas nervuras as guais sofrem nova dicotomia, formando quatro outras e assim por diante. Em Sph. cuneifolium a nervura ünica que penetra na base foliar, forra quatro nervuras, as quais mais adiante sofren algumas dicotomias, o que sem dūvida constitui uma diferença fundamental.

Comparamos o nosso material com descriçöes e ilustrações de mais de outras sessenta espëcies do gênero sphenophyllum, chegando a conclusão de que ele apresenta diferenças morfológicas, ainda maiores com essas.

Na amostra C34 $(a, b)$, hä dois fragnentos de caules (C34D e C34F) sem folhas, talvez relacionadas ao mesmo ti po de vegetal, mas com dimensões um pouco matores, chegando a $3,3 \mathrm{~mm}$ de largura mäxima. Lundgvist (1961, p. 24) tambë̀n notara esse tipo de fragmentos, com atë $5 \mathrm{~mm}$ de largura.

d. Material estudado. Procedencia e Coletor Campo 115, da Cia. Carbonífera do Cambui, Município de Curiuva, Estado do Paraná, leg. R8sler, 1971 - C33, C34A, C34B, C34C, C34D, C34F, C46, C84 e C86 (Holötipo).

nito, Grupo Tubarão.

\section{e. Posição Estratigräfica - Formação Rio Bo-m}

F. Fdade - Permiano Infexior. 
Gênero ANNULARTA stenberg, 1.823

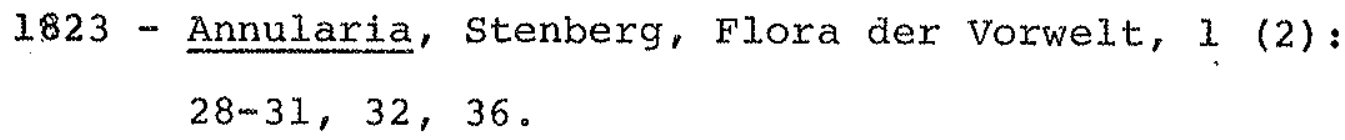

No material estudado temos algumas formas que seguramente podem ser atribuidas a esse gênero. O material adiante descrito, sob a denominação de A. readi n. sp. difere de Stellotheca Surange et Prakash, 1962, por possuir folhas inteixa mente livres umas das outras. Difere de Phyllotheca Brongniart, 1828, principalmente por não apxesentax bainha em nenhum dos espëcimes examinados. Existe alguma semelhança com o gênero Lobatannularia Kawasaki, 1927 (= Annularites Halle, 1927). No entan to, a anisofilia verificada no verticilo dos exemplares paranaen ses ë muito pequena em relação a das espëcies daquele gênero.

A confirmação, agoxa vexifficada, da existência deste gênero nessa floxa, ê interessante sob värios aspectos. Tem-se admitido frequentemente, que esse gênexo corresponderia a folhas pertencentes a plantas com caules do tipo Calamites. Cau les desse tipo não tem sido encontrados nas camadas em estudo. por outro lado é grande o nümero de exemplaxes de paracalamites nos afloramentos aqui considexados, dos quais não conhecemos os örgãos foliares correspondentes.

Essa ë uma situação que se repete na região de Tunguska (Sibêria)。 Por esse motivo se pode admitir como pos sIvel, uma maior relação entre Annulaxia e paracalamites.

Os exemplares de Annularia encontradas no Estado do Paranä, pertencem a duas espëcies: A. readi e A. occidentalis. 
Annularia occidentalis n. sp. Est. 2 Fig: 8

? Annularia australis Lundgvist, 1919, p. 23, Tol 2, fig. 17

? Annularia ? americana Read, 1941, p. 86, Est. 6, fig. 3 e 5

Annularia ? americana Dolianiti, 1948, Est. 3, fig.3 Stellotheca? robusta Rigby, 1970, p. 576

Stellotheca robusta Rigby, J.970, p. 576

do Parană, leg. RÜslex, 1972, T370 a

a. Holótipo - São João do Triunfo, Estado

b. Diagnose - Verticilos maiores com folhas

totalmente livres. Verticilos menores com bainha de até $1 \mathrm{~mm}$ de largura. Folhas de forma geral intermediäria entre oblanceolada e espatulada. Apice foliar com uma ponta destacada, formando um "mucron" atenuado. Comprimento entre $5,0 \mathrm{~mm}$, e largura mäxima atingida por cada folha, entre $1,8 \mathrm{~mm}$ e $3,4 \mathrm{~mm}$.

c. Descrição - Os caules ten entrenós cujo comprimento, medido em dois exemplares, varia entre 17,5 ram e $20,0 \mathrm{~mm}$, e largura entre 1,2 e $20,0 \mathrm{~mm}$. Num dos exemplares (C 85) è percebido um nümero superior a 10 finas extrias longi tudinats.

As follhas estão dispostas formando verticilos de 14 folhas. Essas têm de $5,0 \mathrm{~mm}$ a $16,5 \mathrm{~mm}$ de comprimento e de $1,8 \mathrm{~mm}$ a $3,4 \mathrm{~mm}$ de largura, essa medida, representando o máximo atingido em cada folha, o que acontece na sua meta de distal. A partir dessa parte mais larga, o limbo passa a se atenuar em direção ao äpice, apresentando porēm, nas folhas maiores, um "mucron" apical. Nas folhas menores o äpice è agu do, não apresentando o aspecto acima citado. A forma geral da folha è, nessa espēcie, intermediária entre oblanceolada e espatulada.

A nervura ünica tem largura entre $1 / 4$ e $1 / 3$ da maior largura da folha, e percorre medianamente todo o lim- 
bo, penetrando na ponta apical. Nos verticilos menores, pode-se notar uma bainha de aproximadamente $1 \mathrm{~mm}$ de largura unindo as fo lhas na porção basal. Nos verticilos maiores, as folhas são totalmente livres atẻ o ponto de sua inserção, não tendo sido observado a existência de bainha, nem de qualquer outra união entre elas.

Em todos os casos, cada verticilo apresenta uma anisofilia que é evidenciada particularmente quanto ao tamanho das folhas. porëm, as folhas maiores não chegam a ter o dobxo do comprimento das menores, no mesmo verticilo, conforme pode ser verificado nas medidas adiante apresentadas.

$$
\begin{aligned}
& \text { d. Medidas - Ver Tabela } 5 \text { e } 6 . \\
& \text { e. Discussão - Em comparação com as diferen- }
\end{aligned}
$$
tes espëcies de Annularia já descritas, a nova espëcie aqui versada, mais se assemelha, às seguintes: Annularia ? americana Read, 1941, A. readi (descrita nesse volume), A. mucronata Schenk, 1883 (in Boureau, 1964, p. 174-176) e A. stellata (Schlotheim) Wood, 1860 (in Boureau, 1964, p. 181-183). Deve ainda correspon dex coespecificamente ao que Lundquist (1919 p. 23) denominou de A. australis.

Comparando nosso material com A. ? americana, baseados na descrição e figuras apresentadas por Read (1941, p. 86-88, Est. 6, fig. 3 e 5), notamos aifexenças quaxto ao äpice das folhas, que na espëcie de Read, ë arredondado. Alem disso, - verticilo conta com apenas 12 folinas. No aspecto geral e nas dimensões é muito semeliante. Pelo que se pode observar nas fig. 3 e 5 da Est. 6 (Read, op. cit.), os äpices das folhas não estão bem expostas. por outro, os quatro verticilos da fig. 3 estão incompletas, e aparentemente, o mesmo acontece com o da fig. 5. Como não tivemos acesso aos dois exemplares sobre os quais Read baseou sua descrição, e as informações conti das nesta são insuficientes para uma comparação mais conclusiva, não podemos ter certeza sobre a coespecificidade com o material ora descrito.

Dolianiti (1948, p. 14) cita A.? amexicana Read, 1941 e apresenta na Est. 3 da fig. 3, uma fotografia de um exemplar com 7 verticilos. Alëm destes apresentarem 14 folhas, os äplces não são arredondados. Os demais aspectos observäveis 
naquela fotografia, tambëm coincidem com os de $\mathrm{A}$. occidentalis, aqui descrita.

Em comparação com A. readi (nesse volume), verificamos que $\underline{A}$. occidentalis tem folhas mais curtas e a relação comprimento/largura è bem maior. A. occidentalis se assemelha mais com Annularia mucronata, enquanto que $\underline{A}$. readi se assemelha mais com $\underline{A}$. kurzit.

Tambēm quanto ao äpice, a forma da folha è distin ta, entre as duas espécíes (A. occidentalis e A. readi). A. readi tem - äpice mats agudo formado pelo atenuamento constante dos bordos a partir parte mais larga do limbo. Em $\underline{A}$. occidentalis nota-se uma ponta distinta.

Comparando A. occidentalis com A. mucronata, nota mos grande semelhança no aspecto geral e nas dimensões das folhas Ver

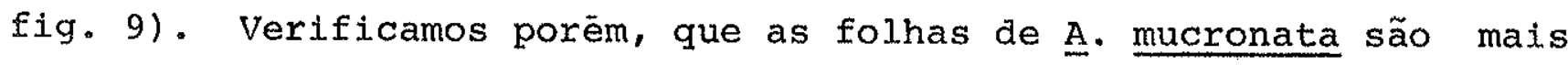
espatuladas, e o mucron apical ë, portanto mais distinto.

Nas folhas figuradas por Cridland (1968, pl. 1, f1g. 2, pertencentes a A. mucronata (Carpannularia americana Elias) de material coletado prōximo a Clinton, Missouri, nota-se um ápice com forma semelhante ao que descrevemos para A. occidentalis. Não observamos, entretanto, em nosso material, a existência de pelos na superficie abaxial das folhas e da bainha, características de A. mucronata.

Em comparação com $\underline{A}$. stellata, a semelhança jä. $\ddot{e}$ mator. o comprimento das folhas desta varia entre $14 \mathrm{~mm}$ e $75 \mathrm{~mm}$ (principalmente $25 \mathrm{~mm}$ a $30 \mathrm{~mm}$ ), enquanto que, em A. occidentalis varia entre $5,0 \mathrm{~mm}$ e $16,5 \mathrm{~mm}$. Além disso, o número de folhas por verticilo é bem variāvel e em mëdia maior em $\AA$. stellata (13 a 32 folhas) contra um nümero aparentemente fixo, de 14 folhas em nosso material.

f. Material estudado e procedência - O material a seguir relacionado procede de duas localidades: São João do Triunfo o. Camhut (vide fia. 2). 
Material procedente de São João do Tri unfo, Estado do Paraná:

T370a (holötipo), molde com três ver ticilos completos ligados a um ramo com entrenós visiveis.

T370b - molde - Contraparte de T370 a

T369 - molde - Fragmento de um verti cilo

T 435 - molde - Fragmento de um verticilo

T 27a - molde - Fragmento de um verticilo (Parte jovem)

T 27b - molde - Contraparte de T 27 a

T 97 - molde - Fragmento de um verti cilo

Material procedente de Cambui, Municipio de Curiuva, Estado do Paranä:

C 85 - molde com restos de película carbonosa, verticilo completo, ligado a fragmento de caule.

9. Coletor.- Todo o material estudado foi coletado pelo autor.

to, Grupo Tubarão.

h. Posicão estratigrăfica - Formação Rio Boni

i. Idade: Permiano Inferior. 
Annularia readi n. sp.

Est. 2 - Fig. 6-7

ROsler, r 50a。

a. Holötipo - São João do Triunfo, Pr., leg.

b. Diagnose - Plantas com caules simples, ar ticuladas, com relação nümexo de estrias e largura do caule (com primido) entre 3,7 e 5,0. Verticilo foliar formado por 34 fo1has lineares, agudas, cuja maior largura é atingida na metade do seu comprimento ou mais distalmente. Pequena anisofilia no verticilo. En geral, com folizas mais cuxtas que os entrenös infrapostos.

c. Descricão - Os caules com 0,8 a $2,5 \mathrm{~mm}$ de largura, apresentam 9 estrias longitudinais perceptiveis, formando uma relação con o nümero de estrias e largura do caule entre 3,7 e 5,0 .

Verticilo foliax disposto sobre um anel na posição do nö, que forma uma espécie de diafragma no caule: Folhas separadas mesmo em sua base, en geral menos longas que os entrenös infrapostos. Verticilo composto por 14 folhas lineares, agudas, cuja maior largura é geralmente atingida além da metade de seu comprimento. Folhas com atë $20 \mathrm{~mm}$ de comprimento e 2,8 mm de largura, cada com uma ünica nexvura frägil pexcorrendo to do seu comprimento.

d. Discussão - Esta nova espëcie tem grande semelhança com Annularia kurzii. Archangelsky, 1960. Difere desta pela relaçäo formada entre o nünero de estrias do caule e a largura do mesmo, que em nosso materiat e bem superior a da es pëcie da Argentina. Além disso, as folnas dessa nova espécie atingem a sua maior largura da porção mediana ou mais distal. Pe las figuras apresentadas por Archangelsky (1960, pl. 10, fig. 2, pl. 11. a, b, c) e atravës do material que examinamos no Museo de La plata (La plata) e no Instituto Miguel Lillo (San Miguel de Tu cuman) pudemos verificar que esse aspecto è menos fxequente en A. kurzij havendo casos en que a maior largura é atingida pouco antes da metade da folha, fato não observado em nenium dos nossos exemplares. 
Naguelas mesmas fontes ë possivel verificar que em A. kurzii os entrenös são curtos, ou seja, normalmente as folhas são mais longas que os entrenös (fato aliäs comum nas espëcies do gênero Annularia). Esse aspecto é aboralado na descrição daquela espécie (Axchangelsky, 1960, p. 32), embora nas medidas apresentadas em seguida àquela descxição verifica-se que isso nem sempre acontece. Em nossa nova espécie dä-se o inverso: geralmente os entrenōs são mais longos que as folhas.

$\varangle$ bem conhecjdo $\circ$ fato de que essa relação de peride da posição qué o fragmento considerado ocupava na planta. os entrenös são progressivamente menos longos nas proximidades da porção do caule (em direção ao äpice).

Pode-se, no entanto, observar que hä no material que representa $\mathrm{A}$. kuxzi.i uma relativa constância no compri-m mento dos entrenös sucessivos de cada exemplar, fato que não ocorre nas porções apicais das articuladas. Convëm citar aqui, que em nosso material a pega $T 107$ apresenta uma forma que poss velmente corresponde a porção distal de um vegetal da nossa nova espëcie con três verticilos sucessivos. Nesse caso, o entrenó em posição mais apical è o mais curto. Os verticilos foliares apicais são de menor diâmetro, porēm as folhas são proporcionalmente maiores que o entrenö infraposto.

por outro lado, a laxgura do caule em nossos espëcimes ë geralmente menor, fato que contradiz a possibilidade de serem estes espëcimes partes mais antigas de vegetais da mesma espëcié que A. kuxzii.

Hä alguma semelhança com espëcies do gênexo Lobatannularia Kawazaki 1927 (= Annularites Halle, 1927) fato jä discutido acima, ao abordarmos o genero Annularia.

No mesmo afloramento de onde procede toda a sërie tipo de A. readi, apaxece tambern $\underline{A}$. occidentales n. sp., e a comparação entre esta e aquela espécie é feita durante a aiscussão que se segue a descrição desta ültima (päg. 31)..

Ista espëcie é ainda, de cexta forma, semeLhante a A. stellata, espécie comum no hemisfërio norte. Nosso material apresenta contudo, follhas em mëala, bem menores. Alëm do mais, a mëdia de folhas em cada verticilo e muito elevado em A. Stellata (Em torno de 22 folhas). O material estudado apresenta 14 folinas em cada verticilo. 
e. Material estudado e procedência: 0 material estudado procede da localidade são João do Triunfo - Pr. , base da Formação Rio Bonito (Grupo Tubarão), tendo sido coletado pelo autor em setembro de 1972 .

T50a (Holötipo), T50b, T107, T145a, T145b, T435, T530a, T530b。

E. Idade: Permiano Inferior.

Gênero PARACALAMITES Zalesky, 1927

Paracalamites australis Rigby

Est. 2, fig. 9

Nos afloramentos de São João do Triunfo, Camm buí e Teixeira soares encontramos uma grande quantidade de caules articulados, porêm sem qualquer örgão a ele anexado. Todos correspondem às formas descritas como paracalamites australis. que por sua vez apresenta uma variabilidade bastante grande. Acreditamos que não pertençam todos ao mesmo tipo de vegetal e ê possivel alguns deles se relacionem com as Annularia aqui descri tas. 


\section{C -FILICOPHYTA}

Na flora da Formação Rio Bonito no Estado do Paranā, algumas filicöfitas constituem elementos expressivos ao lado das glossopterídeas. Essa constatação reveste-se de ele vada significação, pois esse grupo, geralmente muito bem representado nas floras neopaleozöicas do Hemisfërio Norte, era consi derado como pouco comum nas camadas dessa idade na Bacia do Para nā. A descoberta de frondes férteis, permite um melhor conhecimento das possiveis relações com as filicöfitas do Hemisfērio Norte. Por outro lado a existência de esporos "in situ", asso ciados a essas plantas, dā início a uma nova fase de estudos. Alēm da importância em relação à sistemätica, esse fato permitirá algumas importantes reconsiderações no estudo dos esporos dis persos.

Com base em revisão feita por Rigby

e em parte pelo autor, no presente trabalho, nas camadas gondwânicas brasileiras podem ser considerados os seguintes gêneros de filicöfitas: Asterotheca, Pecopteris, Eupecopteris, Sphenopteris e Tietea. Desses, podemos reconhecer três na Formação Rio Bonito no Estado do Paranā: Asterotheca, Pecopteris e Sphenopteris. Vemos, pelo exposto, que embora as felicineas sejam elementos comuns (pelo menos numa das localidades por nōs estudadas), não se apresentam muito diversificadas. Esse fato permite algumas interessantes considerações sobre sua implicação em aspectos paleogeográficos e outros, que serão abordados adiante.

Dos três gêneros acima citados, Asterotheca $\ddot{\ominus}$ o mais importante. 
Gênero ASTEROTHECA Presl.

Esse gênero compreende um grande nümero de formas de frondes fërteis conhecidas em camadas paleozöicas e me sozōicas de värias partes do mundo. As frondes estēreis possuem pinulas do tipo pecopteris e às vezes, do tipo Sphenopteris. A ocorrência de Asterotheca no Estađo do Paraná é pela primeira vez assinalada. Conforme os resultados dos estudos aqui apresen tados, verificou-se que duas espēcies do gênero Pecopteris descritas por Read (1941), na realidade correspondem a frondes esté reis de plantas de uma espécie de Asterotheca (A. Cambuhyensis). Vérificou-se ainda a ocorrência de uma nova espēcie, $\underline{A}$. derbyi.

Fragmentos de ambas as espécies citadas

são abundantes no afloramento de s. João do Triunfo, ocorrendo tambēm na região dé Cambuí. A conservação de detalhes è geralmente boa, e em vários exemplares ë possivel se observar a morfologia dos sinângios: Estes aparecem sempre comprimidos. Às vezes, por sobre a impressão dos esporângios, encontram-se restos destes, sob a forma de fina película carbonosa. Essa película, devidamente preparada permite a obtenção de conjuntos de esporos muito agrupados entre si e aderidos às paredes do esporângio. Nesses casos, provavelmente a fossilização passou a ocorrex antes de se iniciar a deiscência.

A morfologia dos sinângios, revelada atravēs do estudo dos exemplares paranaenses, nos indica uma grande semelhança com os sinângios do gênero Scolecopteris.s. Semelhanças entre fösseis atribuĩdos aos dois gênexos têm sido jā notada por outros autores. Hirmex (cf. Andrews, 1970, p.212) colocou 
Scolecopteris entre as Asterotheca. A maior parte dos autores aceita a existência das duas unidades. Para Kidston (1887) (cf. Andrews, op. cit.), Asterotheca difere de scolecopteris pelo receptäculo no qual são presos os esporângios e que forma apenas um mamelão, enquanto que, em Scolecopteris ele forma uma coluna ou pedūncula que sustenta os esporângios.

o fato è que Scolecopteris tem sido usado para exemplares fossilizados por mineralização enquanto que Asterotheca para exemplares encontrados sob forma de impressão. Em nosso material temos somente casos de impressão e às vezes peli culas carbonosas porēm felizmente os sinângios são encontrados em diferentes situações, o que nos permite observā-los sob värios ângulos. Vamos usar aqui as seguintes denominações: eixo longitudj.nal do sinângio, é aquele que corresponderia ao eixo de simetria originalmente no mesmo, passando portanto pelo centro do receptāculo; sināngio aberto, refere-se ao sinângio cujos es porângios se afastaram mutuamente na parte livre, permanecendo presos ao receptāculo; sinângio fechado, refere-se à situação que provavelmente precede ao caso anterior, quando os esporângios, ainda imaturos,tocam-se ao longo do eixo longitudinal. No material paranaense, os modos de ocorrência dos sinângios são os seguintes:

1 - Sinângios comprimidos junto ao limbo foliar

A - Sem deslocamento relativo do eixo longitudinal

$$
\begin{aligned}
& \text { a - Sinângios fechados } \\
& \text { b - Sinângios abertos }
\end{aligned}
$$

B - Eixo longitudinal deslocado para posição paralela ao plano da impressão.

2 - Sinângios isolados. 
Nos casos: IA, de certa forma ë mantida a simetria original, gexalmente pentarradial, e os caracteres de Asterotheca são nitidos. No caso lAa o sinângio sofre um achata mento com redução de sua altura, uma vez que as folhas têm a ten dência a se depositarem paralelamente à superfície do fundo da bacia na qual ocorre a sedimentação. Consequentenente as estruturas que permaneçam perpendiculares à superficie da folha, som frexão posteriormente uma compressão, devido ao peso dos sedimen tos que se the sobrepõem. o diâmetro do sinângio assim encon trado evidentemente serä maior em relação ã medida original. No caso $1 \mathrm{Ab}$, os espoxângios sofxeram um achatamento que alterou a sua largura, porêm pouco deverá ter modificado seu comprimento. Vemos aqui que são estruturas alongadas (Fig. 14 ).

No caso $1 \mathrm{~B}$ os esporângios são vistos latem ralmente e quando estão dispostos perpendicularmente à nervura mediana da pinula, tomam o exato aspecto de Dizeugotheca Axchangelsky e De la sota. Facilmente se poderia determinar alguns exemplares como pertencentes a esse gênero. E necessäxio reestu dar, portanto, o quanto Dizexgotheca realmente difere de Asterom theca. Ao que se pode ver pelas figuras que acompanham a descri ção de DIzeagotheca, em Archangelsky e De la sota (1960), nesse gênero o receptāculo dos sinângios estariam aderidos mais pröximos da nervura mediana das pinulas, do que o comumente observado em Asterotheca.

Finalmente no ültimo caso, os sinângios encontram-se desprendidos das pinulas e são encontrados isoladamen te na matriz. Nesse caso são vistos sempre lateralmente. podem ser majs adequadamente observados, uma vez que não hä a superposição que ocorre invariavelmente nos casos anteriores. os sinân 
gios assim observados apresentam nitida forma do tipo scolecopteris.

Lembramos que o gênero Scolecopteris foi es

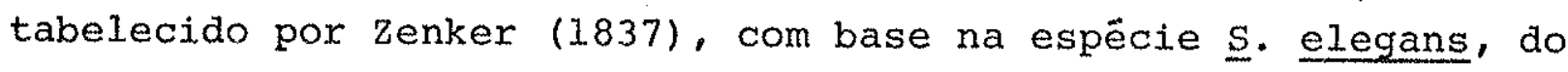
Permiano de Chemnitz, Alemanha. Mais recentemente, muitas espēcies do Carboniffero superior da América do Norte e do Permo-Carbonifero da Europa foram atribuĩas a esse gênero. Na opinião de Andrews (1970), estas espécies deverão ser distribuídas em dois ou mais gêneros. De qualquer forma, pelo que podemos deduzir a partir de nossas observações e estudos, é perfeitamente ví ável uma relação filogenëtica muito intima entre formas de Asterotheca e, pelo menos algumas, formas de Scolecopteris. 
Fig. 9 - Gräfico mostrando uma diferente dispersão para as duas espëcies de Annularia aqui descritas. E considerada nesse gräfico, a rela ção entre o comprimento e à laxgura de cada folha (Ver tabelas 5 e 6). Comparando essas espëcies com outras semelhantes, vemos a maior afinidade, sob esse aspecto, entre $\underline{A}$. occidentalis n. sp., A. americana (conforme figuras de Read 1941), e A. mucronata (espëcie européia)

Por sua vez, $\underline{A}$. readi apresenta maior semelhança com A. kurzi.j da Argentina. De um modo geral, A. readi difere de $\underline{\text { A. occi- }}$ dentalis por suas folhas finas e longas, como mostra o gräfico. Ver tambëm fig. 10. 


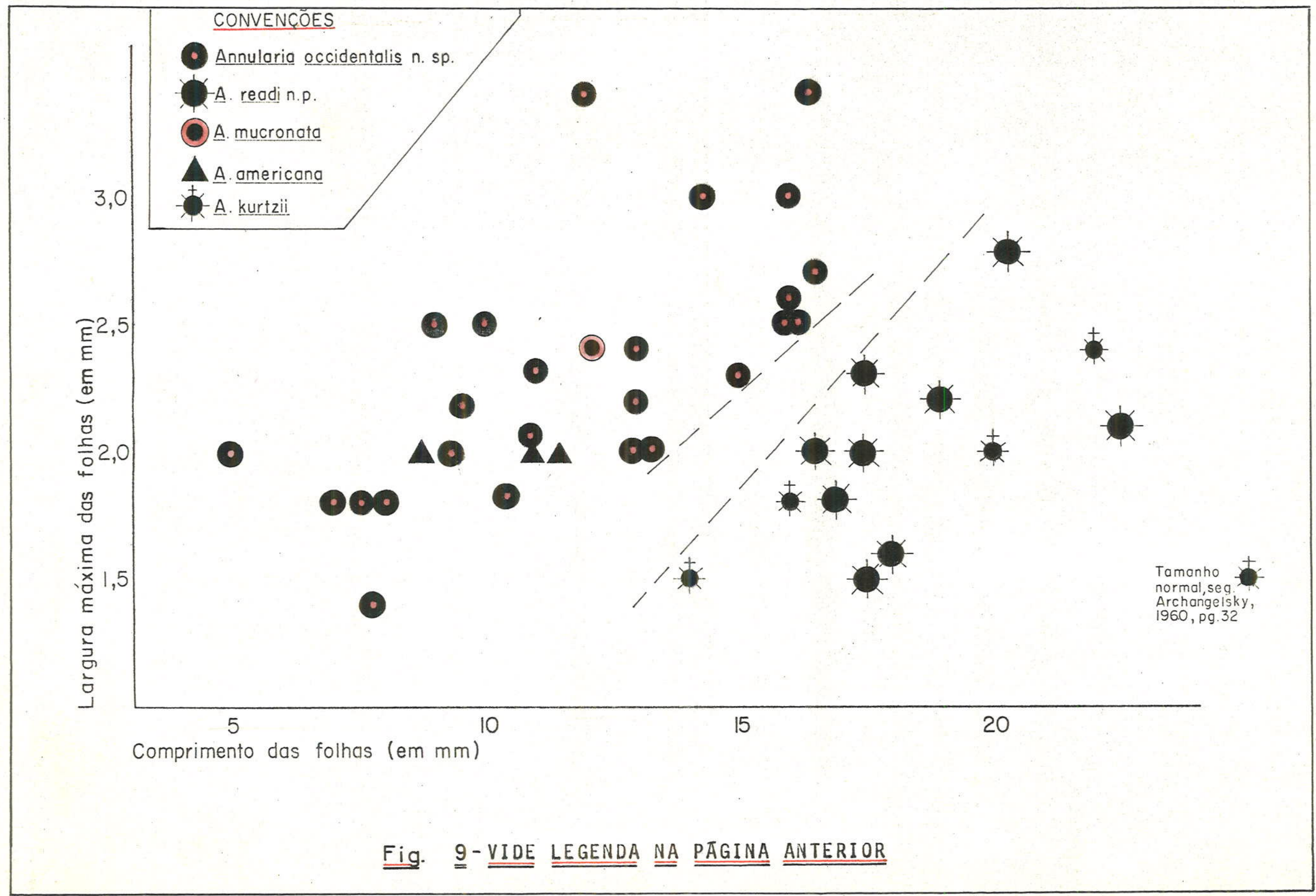


Fig. 10 - Gráfico mostrando a relação entre o comprimento do entrenó do caule e a largura do mesmo. Aqui, o número de dados é menor, pois é pequeno o número de verticilos presos a caules com o comprimento su ficiente para medição dos entrenōs. Mes mo assim, esse gráfico sugere um comportamento diferente para as duas espécies consideradas na fig. 9. teria caules mais estreitos em relação ao comprimento dos entrenós, quando comparados com A. readi. Essa, por sua vez, mantëm a semelhança com a espécie argentina A. kurzii. Os dados numéricos refe rentes a essa, foram tomados de Archangelsky et al. (1960, p. 32). 


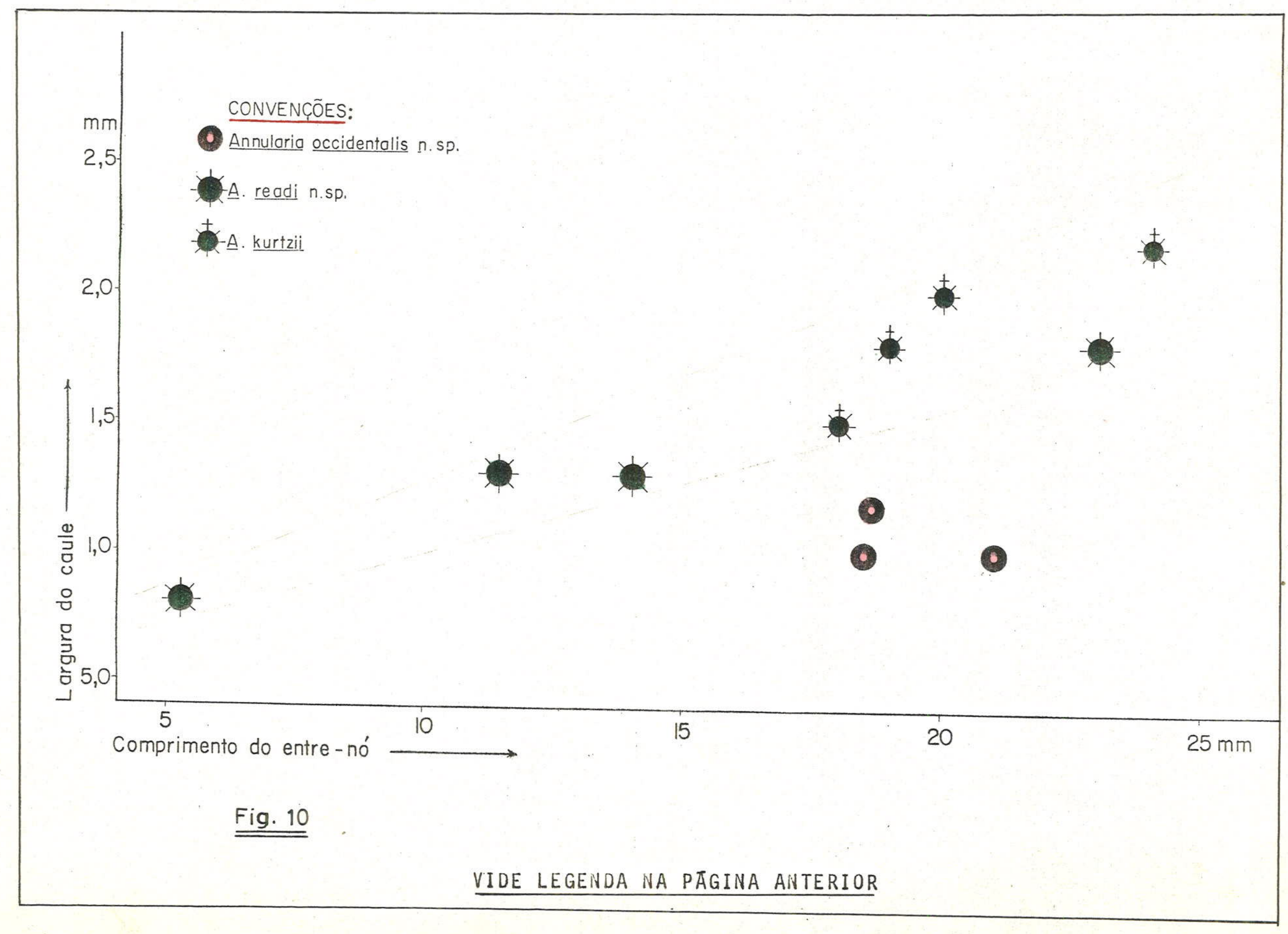


Diferentes situações em que ocorre a fossilização dos sinângios de Asterotheca.

Fig. 11 - Quando ocorre o desprendimento do sinângio, este poderá se fossilizar isoladamente. Nesse caso é depositado lateralmente como se vê na fig. 19.

Fig. 12 - Quando a "abertura" do sinângio se dá anteriormente à fossilização, a impressão que se forma toma o aspecto da fig. 14, exemplar T52. (Ver tambếm estampa 4, fig. 22 e 23).

Fig. 13 - Se o sinângio permanecer "fechado", sua impressão tẹ rá um aspecto semelhante à fig. 17 (Exemplar T83c)

Fig. 14 - Esporângios em vista lateral interna (como na fig.18), dispostos radialmente no sinângio "aberto".

Fig. 15 - Esquema de Archangelsky (1960, p. 101) contendo as formas discutidas no presente trabalho em comparação com o material paranaense.

A, B e C - Ptychocarpus

D, E - Asterotheca

F, G - Scolecopteris

H - Dizeugotheca

$J$ - Pecopteris euneura 


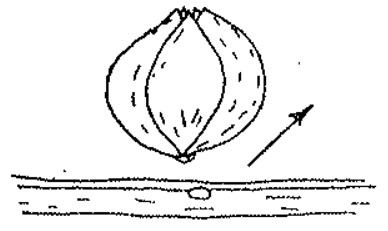

Sināngio em desprendimento do pínula

Fig. 11

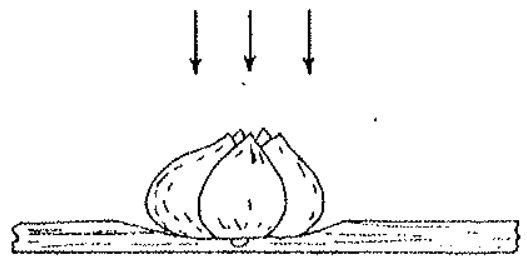

Comp゙êssão do Sinângio fechado

Fig. 13

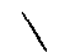

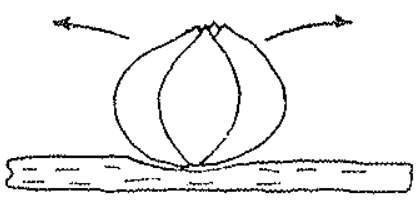

Abertura do Sinângio anterior a compressoo

Fig. 12

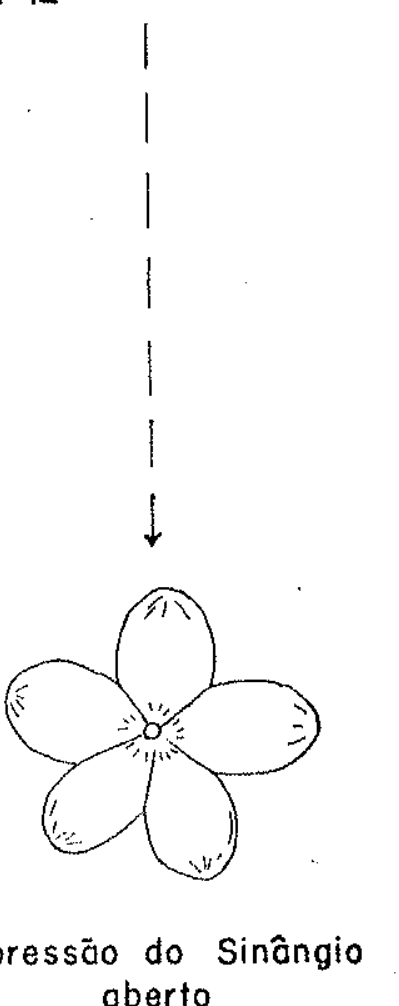

Fig. 14

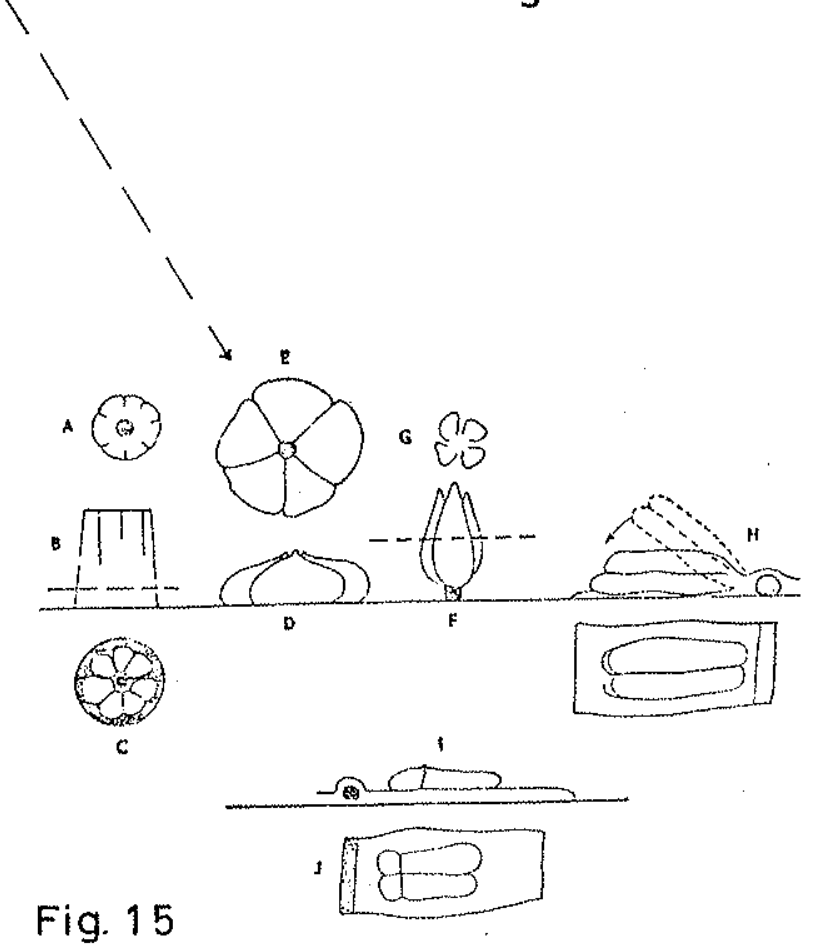




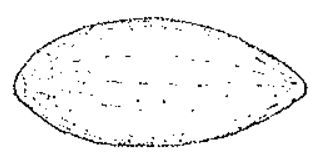

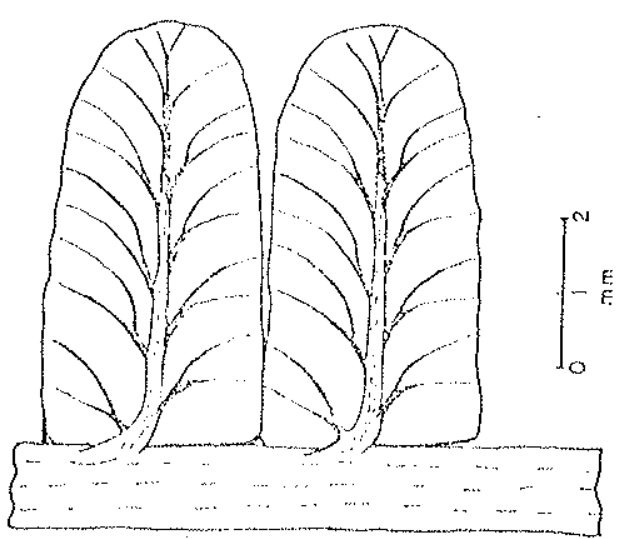

$F \mid G, 16$

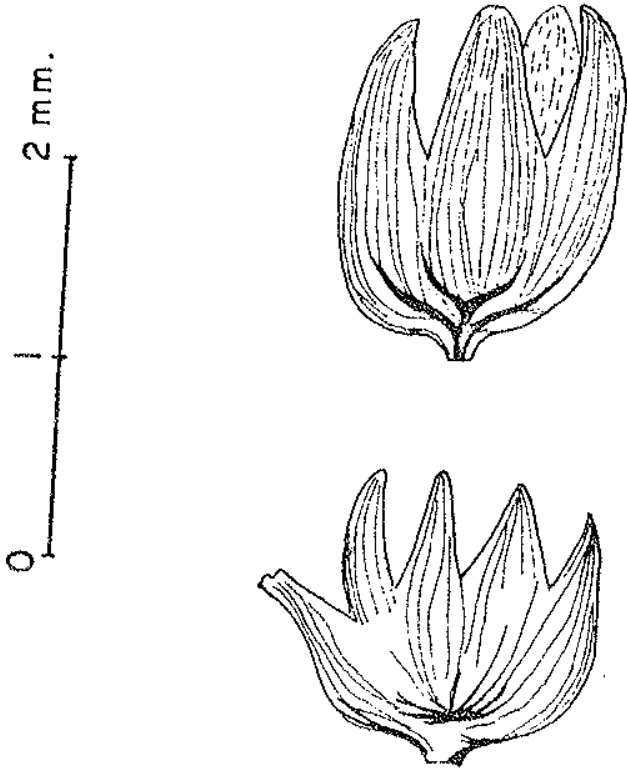

FIG. 19

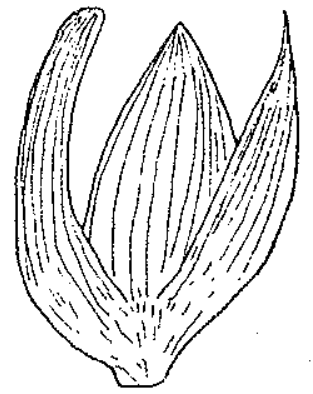

FIG. 18

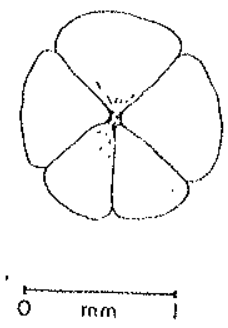

F|G. 17 :

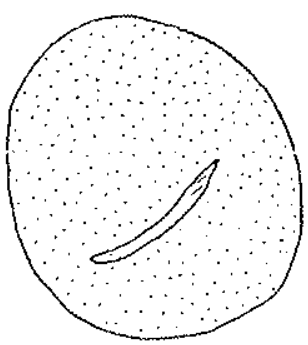

${ }^{0}$

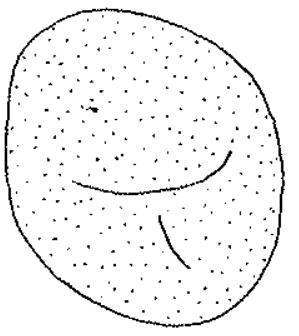

FIG. 20

\section{Fig. $16-21 \quad$ ASTEROTHECA DERBYT}

Fig. 16 - Pinas férteis com sinângios removidos, mostrando a nervação.

Fig. 17 - Tmpressão de sinângio fechado, comprimido, mantendo a simetria original.

Fig. 18 - Impressão de esporângio, visto lateralmente; pode-se observar o comprimento relativamente grande em relação à largura. Ver a reconstituição na fig. 21, comparada com fig. 15d.

Fig. 19 - Sinângios isolados, conforme exemplax T52.

Fig. 20 - Esporos de A. derbyi conseguidos atravës da maceração dos esporângios.

Fig. 21 - (Pägina seguinte) - Reconstituição de parte de pïnula fértil de Asterom theca derbyi. Observe-se a semelhança com Scolecopteris referida no texto.

Fig. 22 - Reconstituições Eeitas por Mamay (1950); A-Scolecopteris incisifolia e B-Eoangiopteris andrewsii. 


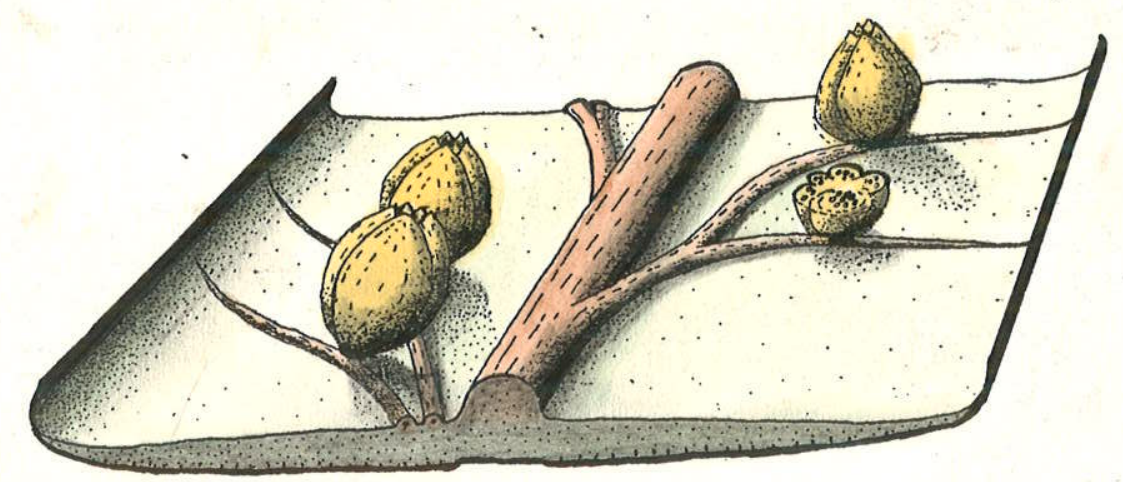

21

Asterotheca derbyi - (original)
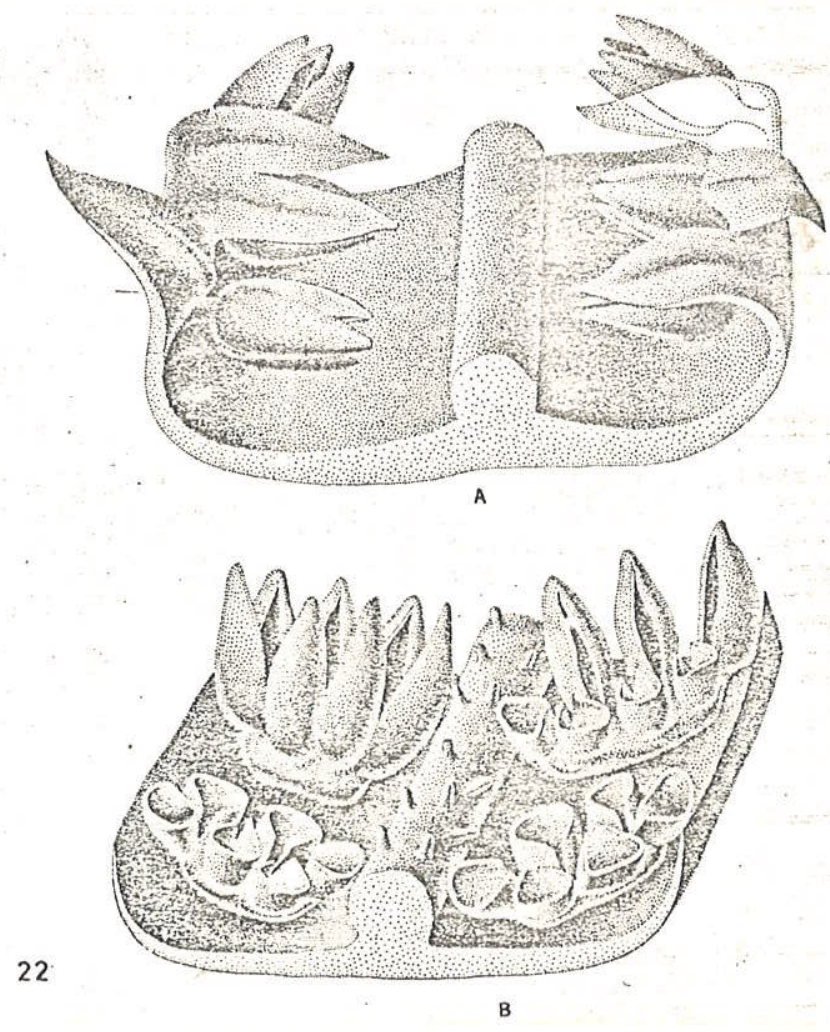

Scolecopteris (Mamay, 1950) 


\section{Asterotheca (Pecopteris) cambuhyensis (Read)}

Est. 3 , fig. $12-15$

1941 - Pecopteris cambuhyensis, Read, p. 74, est. 3, fig. 8-9.

1941 - Pecopteris pedrasica, Read, p. 72 , est. 2 , fig. 6-9.

1953 - Asterotheca piatnitzkyi, Frenguelli, p. 291-293, est. 3 e 4

a. Plesiótipo: Espécime da est. 3, fig. 8 de Read (1941). Ver discussão.

b. Diagnose: Frondes, no minimo bipinadas . Estriação longitudinal nos ráquis e nervuras. Ångulo pina/rāquis, com cerca de 70\%. Maior largura do ráquis da pina entre $0,4 \mathrm{~mm}$ e 2,1 mm. Pinas estēreis com ráquis, em média, mais lar gas que as estéreis.

Pínulas com comprimento atê $9 \mathrm{~mm}$, geralmente $5,0 \mathrm{~mm}$; Relação C/L varia entre 1,4 e 2,3. Nervura mediana decorrente com maior largura entre $0,3 \mathrm{~mm}$ e $0,5 \mathrm{~mm}$. Até 6 pares de nervuras secundárias, bastante arqueadas. Dicotomia, quando existe, ocorre no fim do primeiro terço do trajeto entre a nervura mediana e o bordo foliar.

Pỉnulas fërteis semelhantes às estéreis, porém em média, um pouco menores. 3 a 6 pares de sinângios justạ postos, pentasporangiados. Esporângios ovalados com esporos mo noletes ou pseudo-triletes finamente punctuados, quasilaevigate, com diâmetro de cerca de $35 \mu$. 
c. Descrição: Frondes no mínimo bipinadas. Os fragmentos incompletos chegam a medir $50 \mathrm{~mm}$ de comprimento e $52 \mathrm{~mm}$ de largura. Ráquis principal estriado longitudinalmente, atingindo $3,5 \mathrm{~mm}$ de largura. Pinas alternas. Ângulo formado com o ráquis principal ē geralmente de 70\%. Em alguns casos , as pinas são arqueadas, com a concavidade voltada para o ápice. Pinas longas e com ápice arredondado. A largura decresce lentamente a partir da base, onde atinge maior valor de até $17 \mathrm{~mm}$, sendo na maior parte dos casos próxima a $10 \mathrm{~mm}$. Răquis das pinas apresentam igualmente estriação longitudinal e estreitamse gradativamente a partir da base. Esse ráquis atinge entre 0,4 e 1,1 mm de largura na parte basal das pinas férteis. Nas pinas estëreis varia entre $1,0 \mathrm{~mm}$ e $2,1 \mathrm{~mm}$.

Pínulas estēreis alternas, curtas, com bordos lisos e āpice amplamente arredondado. Encontram-se justa postas, raramente imbricadas, ou deixando um espaço de atẽ 0,5 mm na parte basal das mesmas, entre si. (Ver medidas na tabela

4 ). Comprimento varia entre 4,0 mm e 9,0 mm, geralmente cerca de 5,0 mm. Largura varia entre $2,9 \mathrm{~mm}$ e $5,8 \mathrm{~mm}$, geralmente cerca de 3,2 mm. Relação C/L varia entre 1,4 e 2,3. Apre sentam-se às vezes com certa decorrência sobre o ráquis.

Nervura mediana das pínulas estéreis sempre decorrente, percorre até $3 / 4$ do comprimento da pínula. Largura maior na base onde mede de 0,3 mm a 0,5 mm de largura. Apresenta-se, às vezes, estriada longitudinalmente. Até 6 pares de nẹ vuras secundārias, decarrentes, formando ângulo inicial agudo , arqueando-se com a convexidade voltada para o ápice, atingindo o bordo num ângulo quase reto. Ângulo de divergência pouco superior a 508. Ås vezes são indivisas, ou sofrem uma dicotomia a 0,5 ou $0,6 \mathrm{~mm}$ da nervura mediana, ou seja, no fim do primeiro 
terço do seu trajeto. Na parte basal das pinas em vias de dife renciação, encontram-se nervuras com duas ou mais dicotomias.

Pínulas fẻrteis semelhantes às estēreis. Sem pre justapostas entre si ou até frequentemente imbricadas, com pequena área de cobertura. Comprimento varia entre $2,3 \mathrm{~mm}$ e $5,2 \mathrm{~mm}$, geralmente entre $3 \mathrm{~mm}$ e $4 \mathrm{~mm}$. Largura varia entre 2,3 $\mathrm{mm}$ e 3,7 mm. Relação $\mathrm{C} / \mathrm{L}$ varia entre 1,0 e 1,5.

Nervura mediana das pínulas férteis, sempre decurrente sobre o räquis. Maior largura na sua base onde mede de $0,3 \mathrm{~mm}$ a $0,4 \mathrm{~mm}$. Superfície do limbo coberta por duas filei ras de sinângios, uma de cada lado da nervura mediana. Cada uma conta com 3 a 6 sinângios justapostos e imbricados quando abertos. Pentasporangiados, às vezes, aparentemente tetrasporangia dos. Esporângios alongados de forma eliptica ou ovalada, às ve zes com um ápice agudo. Grande número de esporos em cadă espo rângio. Esporos monoletes ou pseudotriletes, finamente punctados, quase laevigatae, com diâmetro com cerca de $35 \mu$.

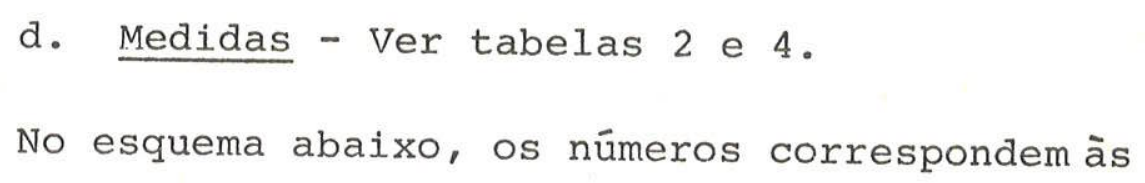


e. Discussão - O material no qual se baseia a descrição dessa espécie provēm do afloramento de são João do Triunfo. Coletamos também algumas pecopterídeas na região de Cambui, das quais quatro espëcimes correspondem a fragmentos de frondes estéreis de A. derbyi. 'As demais, infelizmente, não se encontram bem conservadas.

Como já expusemos no início do presente trabą Iho, as plantas coletadas pelo Dr. Euzébio de oliveira, entre as quais algumas pecopterídeas, foram remetidas ao Serviço Geológico dos Estados Unidos; lä, passaram a ser estudadas pelo Dr. G. White, estudo esse concluido pelo Dr. Charles B. Read. Pelo que é possivel verificar através das ilustrações e descrições cons tantes da publicação dos resultados desses estudos (Read, 1941), aquelas pecopterídeas, embora estejam um pouco melhor conservadas que as por nós coletadas na mesma ärea, a maioria das peças figuradas não apresenta conservação satisfatória.

Com base nesse material, Read (1941) descre-

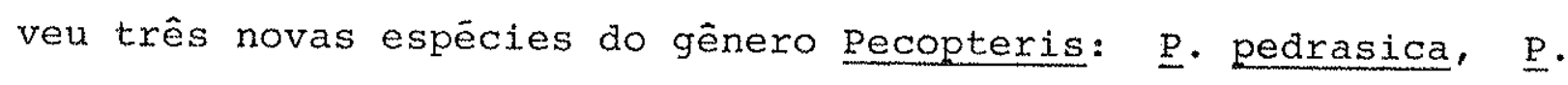
paranaensis e $\underline{p}$. Cambuhyensis. Não tivemos ainda a oportunidade de realizar um reestudo do material do Dr. Read. Esse reestudo torna-se necessärio, face ao próprio desenvolvimento dos conheci mentos paleobotânicos desde a época de sua descrição.

Felizmente, com a descoberta do afloramento de São João do Triunfo, boa quantidade de material pôde ser estú dado e comparado com as descrições e figuras de Read (1941). ES se material, alëm de abundante, apresenta-se melhor conservado que aquele de Cambui e se torna muito importante, pelo fato de 
incluir formas fêrteis. Essas formas fërteis são correspondentes a formas estëreis a elas associadas, que por sua vez, são idên ticas a $\underline{p}$. cambuhyensis Read, 1941. Com isso foi possivel esta belecer os vínculos dessa espēcie com o gênero Asterotheca (Marat tiales - Eusporangi,opsida). Alëm disso, o estudo comparativo de muitos exemplares, nos permitiu verificar as variações da for ma das pinas numa mesma fronde. Constatamos que as formas deno-

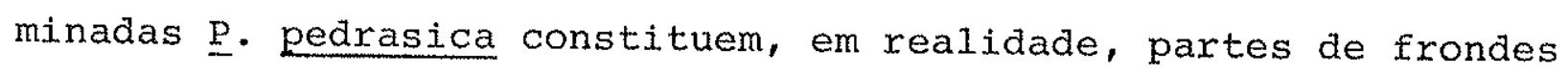
com pinas em vias de difexenciação, que uma vez diferenciadas se tornam idênticas as de $\underline{\mathrm{p}}$. cambuhyensis. Observou-se casos em que as duas formas estão presentes na mesma fronde. Com isso, denominamos a espëcie representada por essas formas, de Asterotheca cambuhyensis.

Devemos lembrar aqui, que o próprio Dr. Read notara a semelhança entre as duas espëcies de pecopteris, confor me se pode lex (Read, 1941, p. 72) :

" Os espécimes designados Pecopteris pedrasica, assim chamados por causa da ocorrência em Cambui, no rio das Pedras, provavelmente são intimamente relacionados a forma aqui descrita como Pecoptexis cambuhyensis. Entretanto, na base de escasso material à mão, è impossivel determinar o grau de parentesco."

A. cambuhyensis estâ tão intimamente relacionam da a A. piatnitzkyi da Argentina, que colocamos esta ültima em si nonimia com aquela. A. piatnitzkyi foi descrita por Frenguelli em 1953. com base em exemplares das camadas permianas do chubut, na patagônia. Esses exemplares haviam antes sido descritos como Pecopteris sp. II.por Feruglio (1933). Frenguel1i (1953) considerou A. piatnitzkyi apenas como novo nome. Em realidade, tratava-se de nova espécie, pois Feruglio não havia dado nenhum epitteto especifico. 
Frenguelli descreve ainda, outras espécies pro cedentes da mesma camada, e de mesma localidade. Entre essas , aparecem Pecopteris pedrasica e Pecopteris cambuhyensis. Archangelsky (1958) e Archangelsky e De la Sota (1960), preferiram incluir essas duas espécies em A. piatnitzkyi, em lugar de colocar esta espécie em sinonímia com uma das espécies de Read (1941). Ar changelsky e De la Sota (1960, p. 96) assim justificam:

"Hemos decidido mantener la especie de Frenguelli, a pesar de la similitud con $\underline{P}$. pedrasica y $\underline{P}$. cambuhyensis, por el hecho de que el material de Read es sumamente fragmentario $y$ esteril. En todas las Felices hasta ahora estudiadas en el Brasil, no se han encontrado fructificaciones del tipo Asterotheca."

Os exemplares por nós estudados, parecem ser bem diferentes daqueles estudados por Lundquist (1919, p. 26 e 27 , est. 2, figs. 28-31). Comparando ‥ cambuhyensis com outras espé cies de Felicíneas, encontramos numerosas formas boreais semelhan tes, principalmente quanto às frondes estēreis. Comparando com formas fērteis, encontramos grande semelhança morfológica com ․ㅡ. oreopteridea, da Europa, e $\underline{A}$. orientalis, de Shansi (China).

Finalmente, encontramos por vezes, certa seme Ihança entre $\underline{A}$. cambuhyensis e $\underline{A}$. derbyi (descrita nesse trabalho), sendo que ambas se encontram associadas. A semelhança mais se ve rifica em relação às partes apicais de $\underline{A}$. derbyi, pois aquela espécie tem as pinulas mais curtas e os răquis mais estreitos. Temse mesmo a impressão de que fragmentos de frondes de $\underline{A}$. cambuhyensis oorrespondem a porções mais distais das frondes de $\underline{\text { A }}$ derbyi. No entanto, uma anālise mais cuidadosa, revela vários aspectos di ferenciais. Número de dicotomias das nervuras secundārias, nūmero de sinângios por pỉnula e relação comprimento/largura das pínu 
las são entre outros, os mais evidentes.

Submetendo os diferentes valores de medidas e relações obtidas em cada espēcie (Tabelas 1 a 4 ) è possível melhor avaliar o grau de proximidade entre as populações de elementos dessas espëcies, em relação aos parâmetros considerados. (Ver gräficos das figs. $23,24, .25$ e 26).

f. Es colha do plesiōtipo - Read (1941), ao descrever pecopteris cambuhyensis não nomeou um holótipo para essa espēcie. Admitimos que esse material ainda exista junto às coleções do Serviço Geológico dos Estados unidos da América do Norte. Com isso elegemos o exemplar figurado na estampa 3 figuras 8 e 9 do trabalho de Read (op. cit.), por ser ele o melhor conservado, se gundo esse autor (p. 76).

g. Material estudado - o material por nös estu dado procede do afloramento de são João do Triunfo - Pr. (Fórmação Rio Bonito) e foi coletado pelo autor: T21, T31A, T35A, T46A, T60, T61B, T83, T93A, T113C, T155, T156, T157, T180, T182, T183, T195A, T196A, T237, T353, T391B, T397, T406, T408, T426.

h. Ocorrência -

Estado do Paranā (Formação Rio Bonito - Grupo Tubarão)

Rio das Pedras - Cambuí

São João do Triunfo

Argentina - em camadas do Lubeckense inferior. Provincia de Santa cruz - Bajo de La Leona:

Laguna Polina

Laguna Castellanos 
Provincia Chubut:

Betancourt

Ferraroti

Piedra Shotle

Perfil Lagunas Secas

Aguada las Mulas

Nueva Lubecka

i. Idade - Permiano Inferior 
Asterotheca derbyi, n. sp.

Est. 4 - fig: 19-23

a - Holōtipo - T112a - Coleção paleobotânica do Instituto de Geociências da Universidade de são Paulo. Cole tado pelo autor no afloramento de São João do Triunfo - Pr., em setembro de 1972. Formação Rio Bonito (Grupo Tubarão) - Permia no inferior.

$$
\text { b - Diagnose - Frondes pelo menos bipinadas. }
$$

Răquis principal com maior largura variável entre $3,0 \mathrm{~mm}$ e 8,0 mm. Pinas longas, margens subparalelas, ápice arredondado.

Pínulas estéreis alternas, decorrentes sobre - răquis da pina. Pínulas próximas entre si, justapostas ou distanciadas até $1 / 8$ da largura das mesmas. Comprimento das pí nulas, cerca de $7,0 \mathrm{~mm}$, atingindo $13,0 \mathrm{~mm}$. Relação $\mathrm{C} / \mathrm{L}$ varia entre 1,5 e 2,6 , comumente cerca de 2,0 . Nervura mediana sempre decorrente. Nervuras secundárias com até duas dicotomias, a primeira muito próxima à nervura mediana.

- Pínulas férteis semelhantes às estēreis, porêm às vezes com bordo ondulado e base um pouco alargada. Atin gem 11,0 mm de comprimento, em geral 6,0 mm a 7,0 mm. Relação $C / L$, varia entre 1,6 e 3,1 , comumente 2,0 a 2,5. Sinângios petasporangiados dispostos em duas filas de 5 a 11 unidades em ca da fila. 
c. Descrição - Frondes pelo menos bipinadas com maior largura, em fragmento incompleto (T391A), de $120 \mathrm{~mm}$. Maior largura do ráquis principal varia entre $3,0 \mathrm{~mm}$ e $8,0 \mathrm{~mm}$.

Pinas alongadas, com largura decrescendo lentamente da base ao ápice, o qual se apresenta estreito e arredondado. Pinas mais longas com margens paralelas na parte proximal. Maior comprimento, è de $80 \mathrm{~mm}$ em pinas férteis e igual medida para as estéreis incompletas. Largura atinge 26 mm. Ångulo formado 'com răquis principal, de $60 \%$ a 808 . Em mui tos casos há pequeno arqueamento das pinas com a concavidade vol tada para o ápice da "fronde". Nas impressões, as pinas aparecem geralmente imbricadas, com área de cobertura atingindo 1/3 da área distal das pínulas.

Pínulas estēreis alongadas com ápice arredondado, bordos lisos e subparalelos. Formam ângulo de 608 a 908, geralmente 808 , com o ráquis da pina. Base decorrente sobre este ráquis. Pỉnulas próximas, entre si, tocando-se na base, ou deixando um espaço de até $1 / 8$ da largura da pínula nessa parte. Em direção ao ápice, mantém constante a distância entre si ou se afastam um pouco até cerca de $1 / 4$ da largura da pínula (Ver tabela de medidas). Comprimento das pinulas cerca de 7,0 $\mathrm{mm}$, atingindo até 13,0 mm. (Exemplar C96A). Largura medida na parte basal, com cerca de 4,0 mm, atingindo 5,1 mm (Exemplar T391A). Relação C/L, varia entre 1,5 e 2,6 , comumente cerca de 2,0 .

Nervura mediana sempre decorrente, estriada longitudinalmente, percorre mais de $90 \%$ do comprimento do limbo. Estreita-se gradativamente a partir da base, onde tem de $0,4 \mathrm{~mm}$ a $0,7 \mathrm{~mm}$ de largura. Nervuras secundárias em número de 6 a 7 pares por pinula, formando um ângulo agudo junto à nervura mediana e fortemente arqueadas, indivisas ou sofrendo até duas di cotomias (três dicotomias nas duas pínulas maiores do exemplar T391A). A primeira dicotomia muito próxima da nervura mediana, geralmente a $0,5 \mathrm{~mm}$ dessa. A segunda dicotomia ocorre entre 1,0 e $1,6 \mathrm{~m}$ da nervura mediana. Angulo de divergência variável em torno de 50 . rém em alguns casos com bordos ondulados e base um pouco alarga da. Atingem 11,0 mm de comprimento (T144), em geral de 6,0 mm. 
a 7,0 mm. Relação $C / L$ varia entre 1,6 e 3,1, comumente 2,0 a 2,5. Nervura mediana atinge as proximidades do ápice, e mede, na base, de 0,2 mm a 0,6 mm de largura. Nervuras secundārias, geralmente não visíveis devido aos sinângios, apresentam uma dicotomia que ocorre muito próxima da nervura mediana.

Sinângios pentasporangiados, talvez alguns tetrasporangiados, dispostos em duas filas, uma de cada lado da nervura mediana. Cada fila conta com 5 a 11 sinângios, mais comumente cerca de 6 . Ocupam a maior parte da ārea do limbo, e es tão intimamente justapostos. Quando fossilizados apōs a abertura, se sobrepõe uns aos outros. Esporângios elípticos-ovalados com finas estrias curvilineas. Muitas vezes apresentam películas carbonosas nas quais se conservam agregados de várias dezenas de esporos. Esporos esféricos, achatados por compressão , com cerca de $40 \mu$ de diâmetro, punctados com marca monelete.

c. Discussão - Esta ē a mais numerosa das espécies de Asterotheca que reconhecemos no Estado do Paraná. Em geral, distingue-se facilmente de $\underline{A}$. cambuhyensis por suas pinulas longas (Tabela 1, coluna XI, e tabela 3, coluna 13); também proporciona fácil diferenciação, o fato de as nervuras sẽcundārias das pinulas apresentarem, em geral, duas dicotomias, ao con trário de uma, em $\underline{A}$. cambuhyensis.

Comparamos as relações entre o comprimento e largura das pinulas, bem como, largura do ráquis da pina com o comprimento das pínulas. Comparamos ainda a largura do răquis da pina com a relação C/L das pínulas, alēm de outros parâmetros. E sa análise revelou-se útil para uma verificação mais objetiva das relações entre os elementos estudados. Alguns resultados dessa análise, podem ser vistos nos gráficos das figuras

- Verifica-se, entre outras cou sas, a existência real de duas espécies de pecopterídeas, as quais, apesar de bem definidas, parecem apresentar certas afinidades entre si. E muito provāvel que as duas espécies tenham re lações filogenéticas muito próximas, dentro do próprio gênexo Asterotheca.

$E$ interessante o fato de que esta espēcie, que aqui ocorre associada a $\underline{A}$. cambuhyensis, apresente grande se melhança com A. feruglioi que também ocorre associada à mesma, 


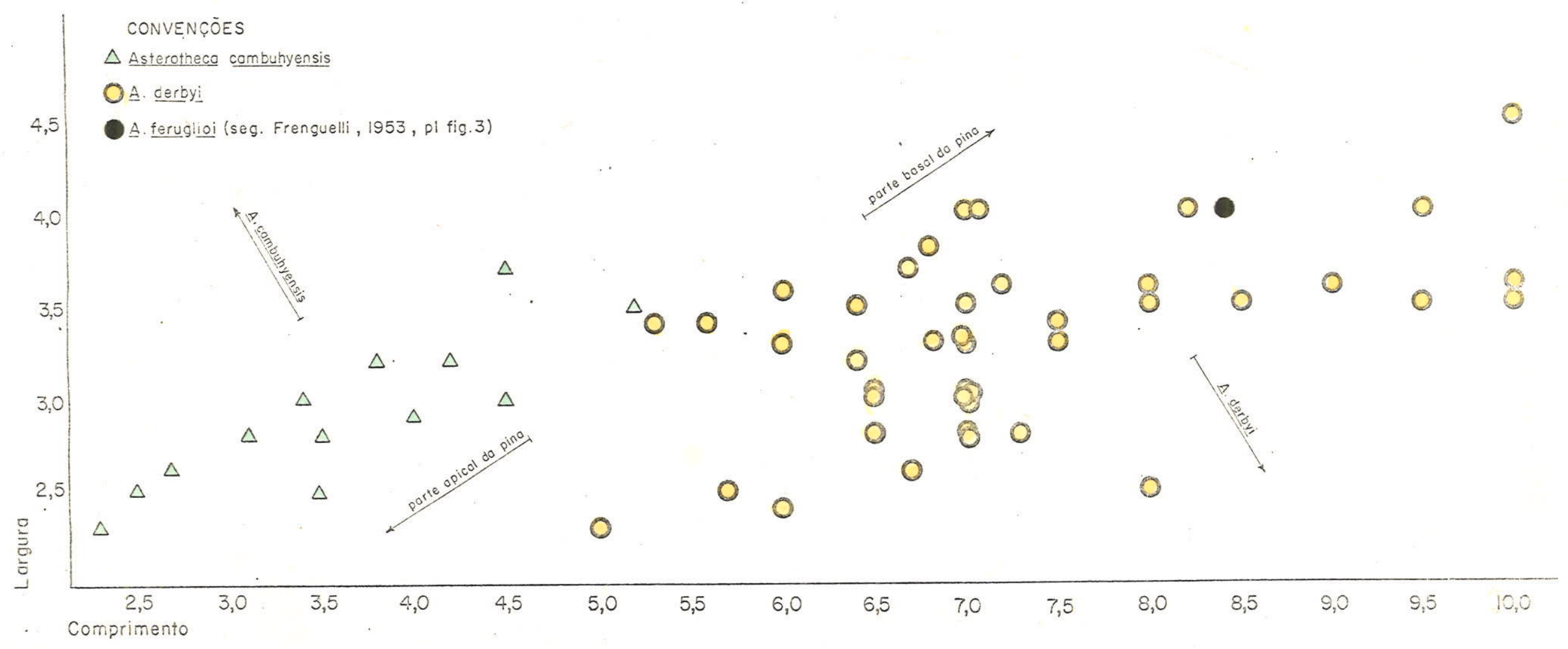

Fig. 23

FIG. 23 -VIDE LEGENDÁ DA FIG. 24 -(PÁG. SEGUINTE) 
OAsterotheca combuhyensis

(A) A derbyi

(6) A feruglioi Frenguelli, 1953

A piotnitzkyi Frenguelli, 1953

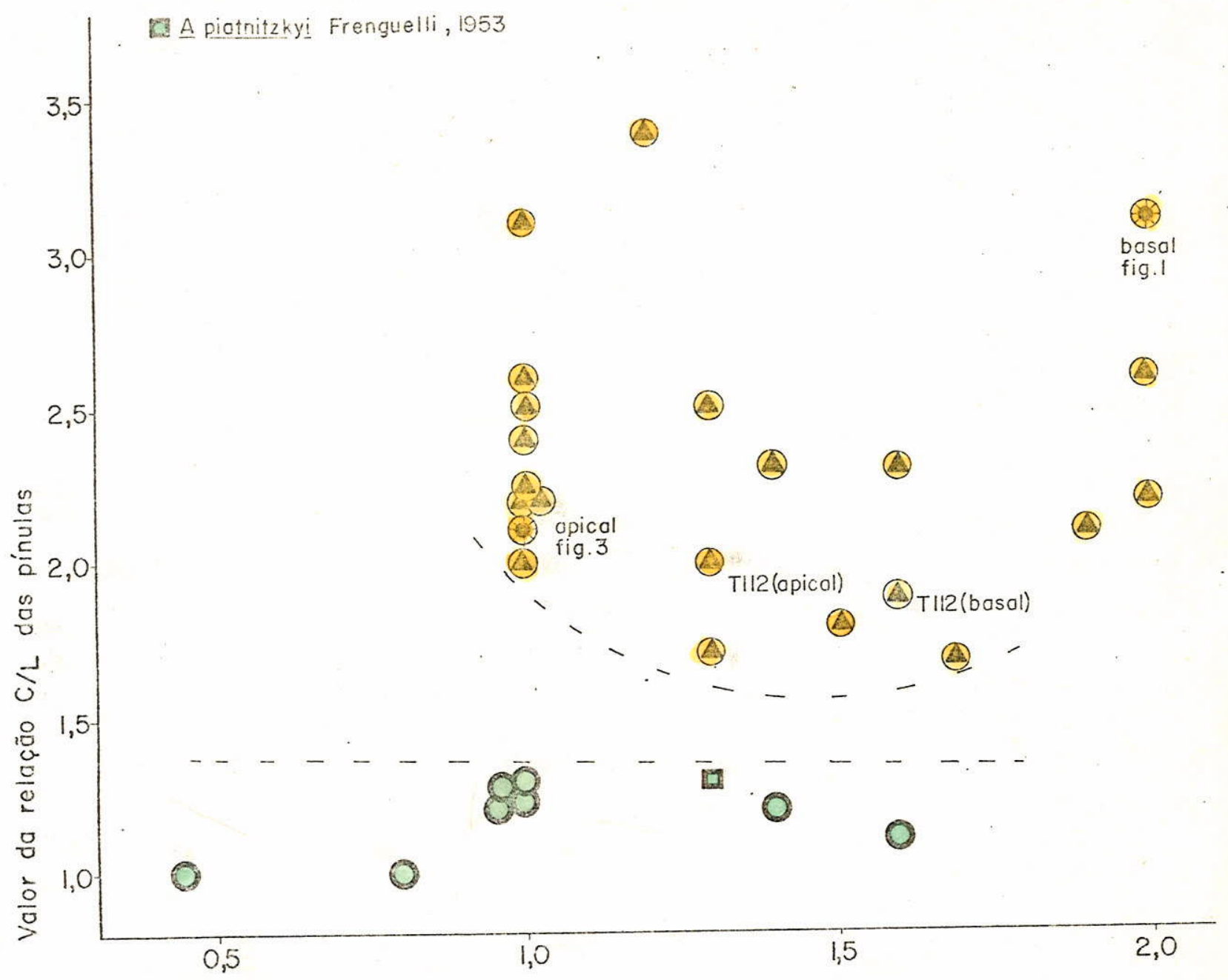

L. do ráquis dos pinos - $(\mathrm{mm})$

Fig. 24

Fig. 23 e 24-Gráficos para análise de parâmetros referentes a frondes férteis de astexothecáceas do Paraná.

Fig. 23 - (päg. anterior) - Gräfico de dispersão, relacionando o comprimento das pinulas e larguras correspondentes (Ver tabelas 1 e 2, colunas XI e XII). Nesse aspecto, $\underline{A}$. dexbyj. se aproxima mais da espécie argentina $\underline{\mathbb{A}}$. feruglioi, que de A. Cambuhyensis. Esta, poderia ser confundida com partes apicais de Eron-

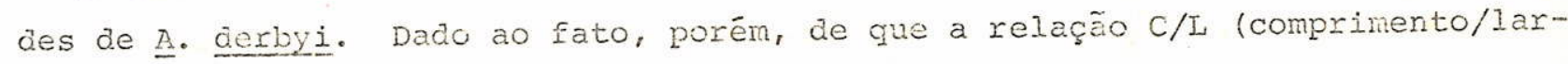
gura) das pinulas é relativamente constante (tabela 1 e 2, coluna XIII), e con siderando-se ainda, gue a largura do ráquis diminui à medida que consideramos pinas situades mais próxinas do ápice, aquele equívoco pode ser contonado, conforme riostra a fig. 24.

Eig. 24 - GLĖco de dispersão, considerando-se o valor da relação C/L das pí-

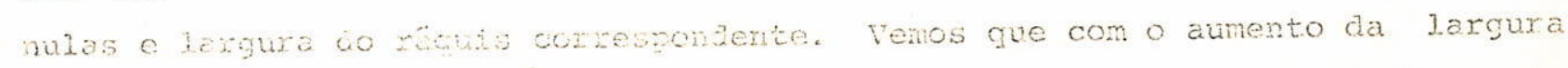
do râquis (em direção à base da fronde), rianién-se relativamente constante à xelacäo C/L das pínulas de A. cambuhyensis. Manten-sc aqui a semelharça de A. derbyi e A. Eeruglioi, espécies muito próxinas e distintas apenas por alguns aspectos norfológicos. 


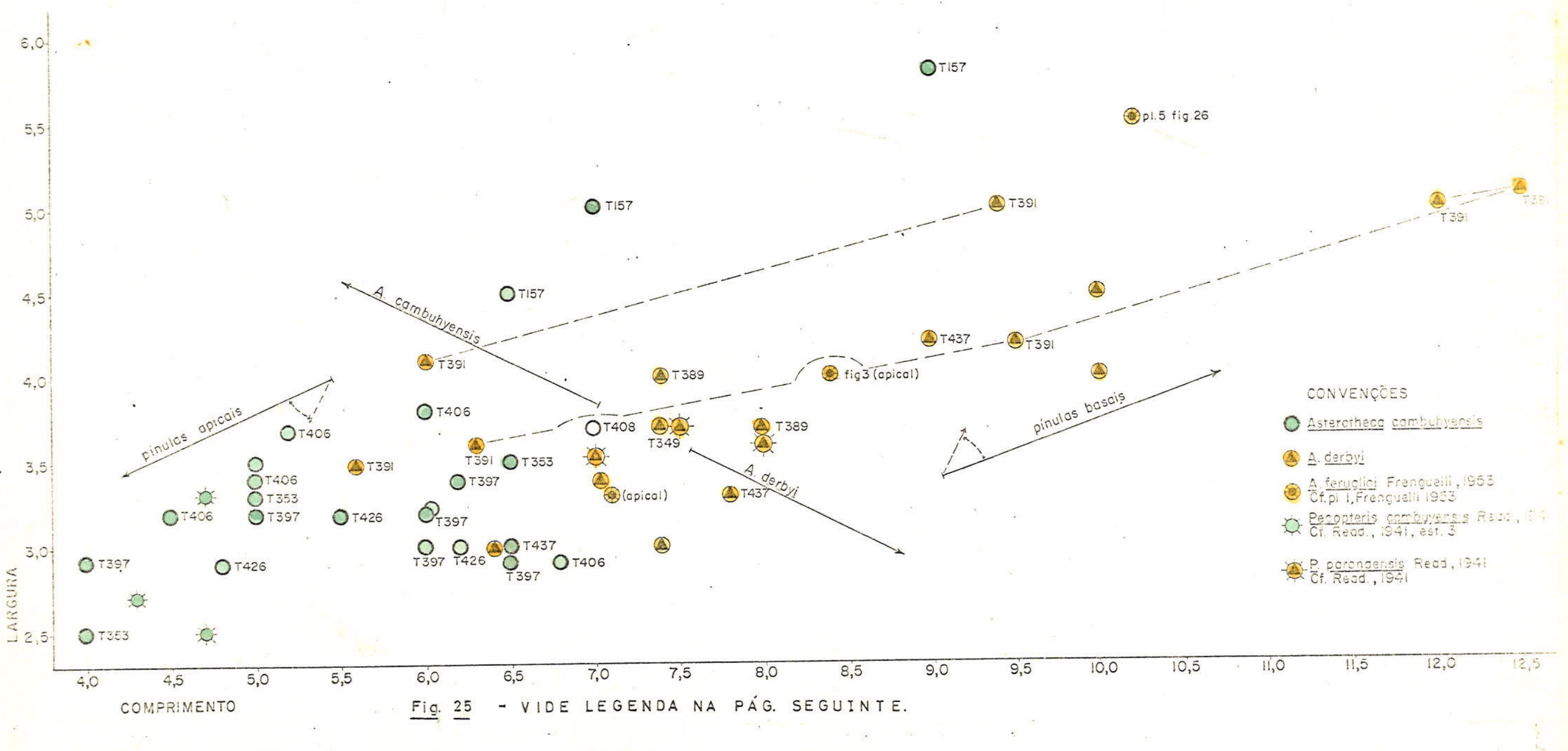


Fig. 25 e 26 - Gräficos mostrando as relações entre as pinas e pinulas estēreis de $\underline{A}$. derbyi e $\underline{A}$. cambuhyensis, além de espécies próximas.

Fig. 25 - (Păgina anterior) - Gräfico de dispersão considerando o comprimento das pínulas em relação com sua maior largura. (Ver tabela 3 e 4, colunas 13 e 14). Da mesma forma que na fig. 23 (pínulas fér teis), as pínulas apicais de $\underline{A}$. derbyi tendem a se confundir com $\underline{A}$. cambuhyensis. No entanto, a distribuição dos pontos tem tendência distinta pa ra as duas espécies. A linha interrompida liga pontos referentes a pínulas de uma mesma fronde.

Fig. 26 - (Păgina seguinte) - Aqui são consideradas as medi das da largura mäxima do rāquis da pina, relacionadas com as medidas do comprimento māximo de suas pinulas (ordenadas). Ver tabela 3 e 4, colunas 5 e 13. A diferença entre as duas espécies é, nesse caso, mais clara. Tambëm se verifica, como nas fig. 23 e 24 , a semelhança entre $\underline{A}$. derbyi e A. feruglioi da Argentina. No presente trabalho,

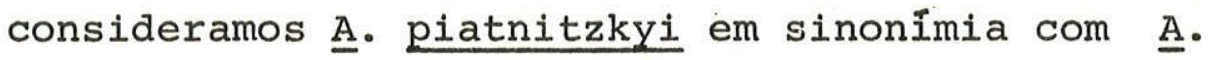
cambuhyensis. 


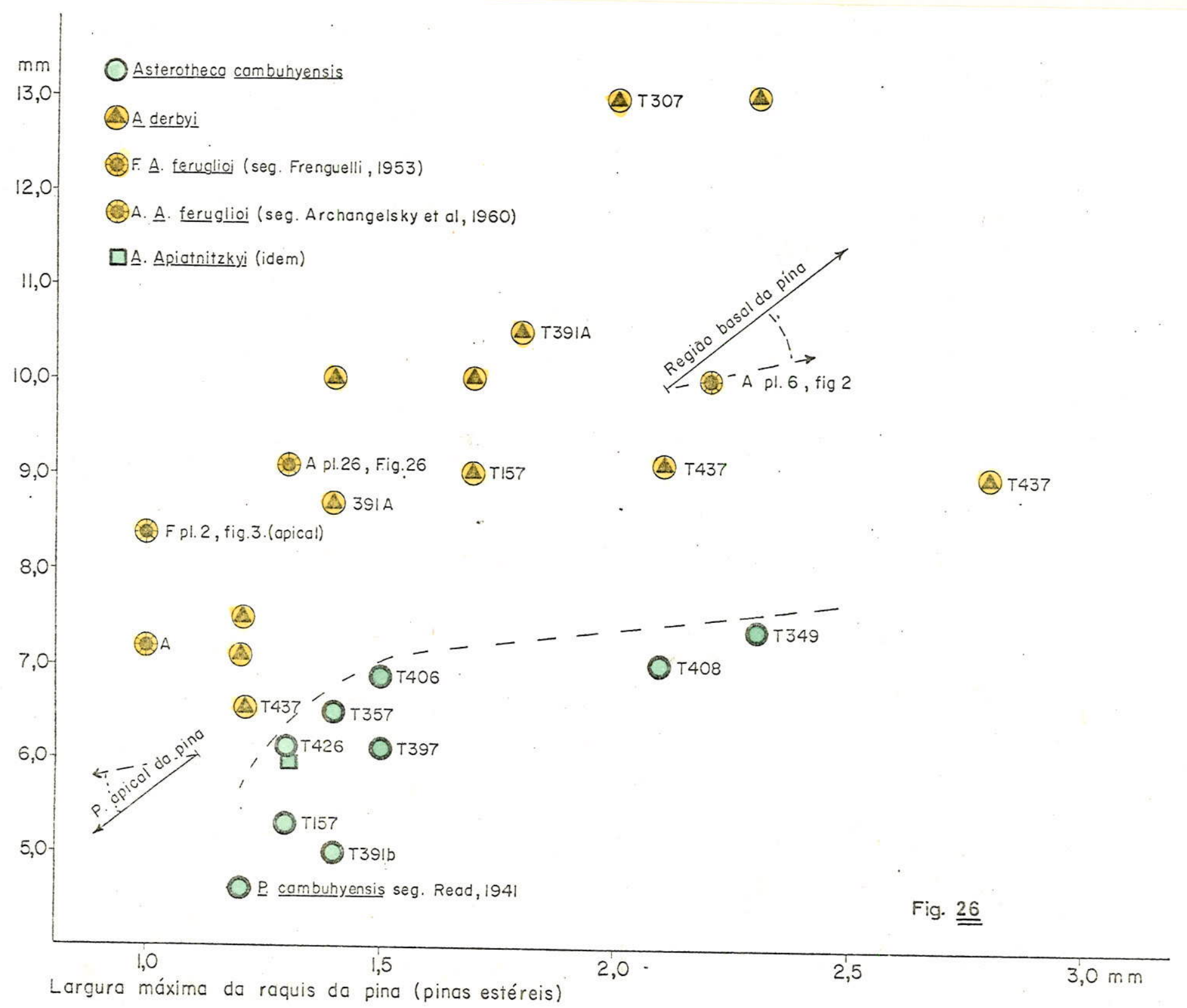


na Província Chubut (Patagônia - Argentina), no Lubeckense inferior. $\underline{A}$. derbyi difere de $\underline{A}$. feruglioi, principalmente pela ne $\underline{\underline{r}}$ vação das pínulas. Na primeira espēcie, a primeira dicotomia das nervuras secundárias ocorre sempre muito próximo da nervura medi ana, mesmo que se verifique apenas uma dicotomia. Em $\underline{A}$. feruglioi, ela ocorre geralmente na metade do trajeto entre a nervura media na e o bordo da pínula. Deve ser observado que a posição das dí cotomias na espécie paranaense è, relativamente, muito constanté, conforme pode ser visto na tabela 3, coluna 19 (la. dicotomia) e coluna 20 (2a. dicotomia).

Além disso, ‥ feruglioi tem, geralmente, as pinulas mais afastadas entre si, sendo que espaço, deixado entre elas, frequentemente atinge medida igual a da largura das mesmas. No caso de $\underline{A}$. derbyi esse espaço é sempre pequeno em relação à largura das pinulas, conforme podemos ver na tabela 3 ( colunas 10 a 12, comparadas com coluna 12). Em outros aspectos $\underline{A}$. derbyi se aproxima muito de $\underline{A}$. feruglioi.

As pinas estéreis de $\underline{A}$. derbyi são, de um mo do geral, semelhantes as de Pecopteris paranaensis, descritas por Read (1941, p. 74, est. 2, fig. 1-5; est. 3, fig. 2 e 3) • O material aí figurado não apresenta boa conservação, o que torna di fícil a comparação. De qualquer forma, pode-se perceber que as nervuras medianas das pínulas, não são decorrentes, ou o são muito inexpressivamente. Em $\underline{A}$. derbyi, a decorrência é acentuada. Ainda se pode perceber que as pinulas são opostas ou subopostas (Read, 194l, pl. 3, fig. 2 e 3). Em $\underline{A}$. derbyi são sempre alternas. O único exemplar figurado, que mais se parece com a espécie aqui descrita, é o que está representado na figura 5 da estampa 2, daquele trabalho, onde apenas duas pinulas estão nîtidas. Porém, com base nas diferenças observadas nos demais espécimes, pode-se afirmar que $\underline{A}$. derbyi realmente é uma espécie dis tinta em relação Pecopteris paranaensis.

A. derbyi não é comparável com nenhum dos exemplares de Pecopteris sp. descritos por Lundqvist (1919). Em aspectos gerais, verificamos uma certa semelhança com A. hemitelioides, ‥ andersonii, pecopteris frenguelli e outras, principalmente, pela forma das pínulas. Porém em todos os casos, nervação è diferente. 
Os sinângios, por sua vez, são comparáveis aos de asterotecáceas do Hemisfériò Norte, o que sugere uma certa afinidade entre essas formas. Os esporos são igualmente comparáveis com formas "nórdicas". Não são muitos os casos de espo ros de Asterotheca encontrados "in situ", em todo o mundo. Mesmo assim, algumas espécies da Europa possuem esporos muito semelhantes aos aqui encontrados. E o caso, por exemplo de Asterotheca meriani Brong., em Potoniē, 1958, do Triássico da Europa.

e. Material estudado - os espécimes aqui estudados provêm de duas localidades do Estado do Parană: São João do Triunfo e Cambuí. Ocorrem sob a forma de impressões, às vezes com restos de película carbonosa. Todo material foi coletado pelo autor, nos anos de 1971 e 1972.

Material procedente de São João do Triunfo:

T18, T22, T37, T39, T40A, T59B, T62, T66, T73, T80, T81, T84, T86, T87A, T93B, T94, T99, T111 A е B, T112, T113B, T123, T135, T144, T150, T151, T152A, T154, T157B, T172, T194, T195B, T198 A e B, T204 A e B, T207B, T210, T230, T349, T350, T351, T363, T365, T366, T368, T372, T377, T384, T388, T389, T391A, T409, T410, T436, т437.

C96A, C96B.

Material procedente de Cambuí: C47, C69,

f. Ocorrência - Esta espēcie tem sua ocorrência conhecida, restrita à formação Rio Bonito, Grupo Tubarão, no Estado do Paraná.

g. Idade - Permiano Inferior. 


\section{PTERIDOSPERMAPHYTA}

Este grupo compreende a ordem Pteridospermales, que foi muito comum durante o Paleozóico superior, sen do conhecidas tambēm algumas formas mesozóicas. Apresentam ge ralmente folhas semelhantes as das felicineas. Como ocorre um grande nümero de folhas estēreis isoladas com esse aspecto, em camadas dessa idade, resulta que sua ligação com um ou outro grupo permaneça muitas vezes em dủvida.

As frondes encontradas nas camadas em estu do, no Estado do Paranā, pertencem ao grupo das Marattiales, como ficou demonstrado no presente trabalho. Devido ao desco nhecimento anterior de elementos férteis, sua posição era ignorada, possibilitando inclusive, admitir-se a possível ligação com as pteridospermas.

Com isso vemos que esse grupo, muito bem representado em floras "nórdicas", está aqui presente apenas com a família Glossopteridaceae.

\section{GLOSSOPTERIDACEAE}

Glossopteridaceae, em realidade, constitui uma familia adicional entre as pteridospermas, das quais não se afigura como representante muito caracteristico. E possivel que seja endêmica na Província do Gondwana inferior, onde seus representantes são comuns.

Essa famỉlia é representada por poucos gêneros, sendo Glossopteris e Gangamopteris os principais. 
ocorrência de ambos foi assinalada no Estado do Paranä. Gangamopteris estaria representado pela espécie $\underline{G}$. obovata, nos afloramentos de Teixeira Soares e Cambuí (Rigby, 1970, p. 576). o gênero Glossopteris é bem melhor representado nestes afloramentos.

\section{Gênero GLOSSOPTERIS Brongniart, 1828}

Todos os exemplares desse gênero por nós coletados nos afloramentos em estudo, pertencem a uma ünica espécie: $G$. communis. Durante a discussão que se segue à des crição desse material, são abordadas as demais espēcies citadas na literatura, para aquelas camadas. 
Glossopteris cormunis Feistmantel, 1876

Est. 5 fig. 24-27

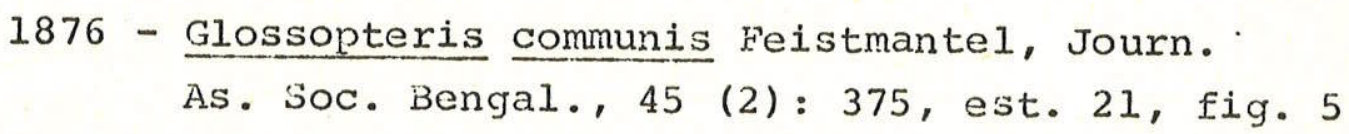

a. Descrição - Folhas simples, inteiras, lanceoladas, ápice agudó e base estrejta. Maior largura do limbo atingida no terço distal, medindo de $25 \mathrm{~mm}$ a pouco mais de 30 mu. Algumas folhas quase completas. Maior fragmento mede 130 $\mathrm{mm}$ de comprimento. Bordo do limbo liso ou suavemente ondulado (ondulação provavelnente devicao a deformações).

Nervura mediana forte, com $1,5 \mathrm{mri}$ a $2,5 \mathrm{~mm}$ de largura na parte basal da folha. Estreita-se gradativamente ein direção à região apical, nesta ainda perfeitamente distinta. Apre senta estriação longitudinal paralela.

ivervuras secundárias com três a quatro dicoto mias bem distintas no primeiro terço do seu trajeto. A primeira aicotomia bem junto à nervura nediana. Além dessas dicotomias outras são observadas no restante do trajeto, bem como, ra ras anastomoses. Conjunto forma malhas muito estreitas e alongadas. Malhas situadas junto à nervura mediana às vezes um pou co mais largas que as situadas no restante do limbo. iJervuras secundărias muito próximas entre si nas imediações do bordo foliar, cerca de 28 por cin. Angulo inicial formado pelas nervuras secundárias com a nervura mediana com valor geralmente pouco inferior a 20\%, mantendo-se agudo no terço proximal destas. Neste terço localizam-se as três ou quatro primeiras dicotomias citadas. Cerca do início dos dois terços restantes as nervuras apresentam um encurvamento mais acentuado, (com a convexidade voltada para ápice). Ângulo de divergência, cerca de 40\%. Seguem até o bordo da folina descrevendo um arco relativamente aber to; Angulo formado com esse bordo, de 45\% a 909, mais comumente de $50 \%$ a $60 \%$. Ás vezes observa-se ligeiro encurvamento das extremidades das nervuras secundārias, junto ao bordo (concavidade voltada para o ápice). Maior largura das nervuras secundārias atinge $0,3 \mathrm{mri}$. 
j. Comentārio e discussão: O material no qual se baseia a descrição acima, apesar de fragmentário, permite uma boa observação dos caracteres norfológicos mais importantes. Pode-se, inclusive, formar uma boa reconstituição da forma geral da folina. Isso é possivel, pois alguns fragmentos, como T167A e T169A são quase corñletos, faltando apenas parte da região apical, que por sua vez, é.encontrada em outros fragmentos. Alguns aspectos sugerem que a nervação secundāria seja definida como pouco proeminente. De fato a nervação normalmente não se apresenta sob forma de sulcos expressivos na matriz. Alëm disso, essas nervuras são normalmente estreitas.

Encontran-se registradas na literatura cientí fica a ocorrência de vărias espécies do gênero Glossopteris no Estado do Paraná. Algumas delas, principalmente G. indica , correspondern provavelmente a espécie aqui descrita. Várias outras não podem ser comparadas adequadarnente, com base nas descrições e ilustrações. E possível, no entanto, que a maior par te dessas pertença também à mesma espécie G. communis. Além dessa espécie, pelo menos, mais outra deve existir nessas camadas, embora possivelmente de ocorrência mais restrita e menos abundante. E o caso de G. orbicularis Feistmantel (Dolianiti , 1954), cujo material deverá ser ainda revisto.

Para melinor clareza, vamos rever e discutir as principais referências sobre Glossopteris das canadas em estudo: Lundqvist (1919, p. 25) descreve exemplares de Glossopterídeas procedente da região de Carubuí (de onde procedem alguns dos exemplares por nós estudados), identificando-os como G. indica Schirn. Pelo que se pode deduzirde sua descriçãoe, principalmente das ilustrações (Lundqvist op. cit., est. 2, fig. 25 , 26), provavelmente se tratan de espécimes coespecíficos con os por nós determinados como G. comrnunis.

Oliveira, 1927, (est. oposta a p. 48) figura um espécime coletado em Teixeira Soares, denominando-o Glossopteris. Pela forma geral do fragmento ali figurado, nos parece possivel tratar-se da parte basal de um espécime de $\underline{G}$. communis. A qualidade da reprodução e do próprio espécine impedem uma determinação mais segura. Outros exemplares de mesma procedência e figurados por Oliveira (op. cit., na ültima das quatro estampas intercaladas entre as páginas 50 e 51), foram determinadas por esse autor como G. indica. Parece-nos tratar-se também de 
G. communis, por comparação com o nosso material.

Ainda Oliveira (op. cit., p. 72), refere-se a restos vegetais encontrados por ele, em 1906, no "grotão a oeste de Teixeira Soares" (corresponde ao vale conhecido hoje por "do Minhocão"). Oliveira comparou os espécimes ali encontrados com os descritos por. White, 1908, das camadas hulheiferas do ES tado de Santa Catarina. Com base nessa comparação, identificou as seguintes espécies do gênero Glossopteris: G. occidentales, G. browniana, G. obovata e $\underline{G}$. $\underline{\text { indica, }}$ as quais estão apenas lís tadas na p. 73 (Oliveira,op. cit.).

Rèad (1941) descreve e figura duas espécies do gênero Glossopteris procedentes do Estado do Paraná: G. indica (p. 78, est. 4, fig. 2; est. 5, fig. 1, 2 e 5) procedente de Cambui, e G. browniana (p. 80, est. 5, fig. 3, 4 e 6) procedente de Cambuí e Teixeira Soares. Amjas apresentam grande semelhança com o nosso naterial, sendo a primeira ao nosso ver , coespecífica com o mesmo. A segunda (G. browniana) segundo Rigby (1970, p. 576), se trata taraérn de G. communis, o que jul gamos perfeitamente viável.

Read (op. cit., p. 78) cita ainda a ocorrên cia de Glossopteris cf. G. ampla Dana, em Cambuí. No entanto , a sua descrição e figuras (est. 4, fig. 3e 5) referem-se apenas um exemplar incompleto, procedente do rio Ferreiro, próximo a Treviso (S.C.).

Dolianiti (1954, p. 149-150, est. 9, fig. 5,

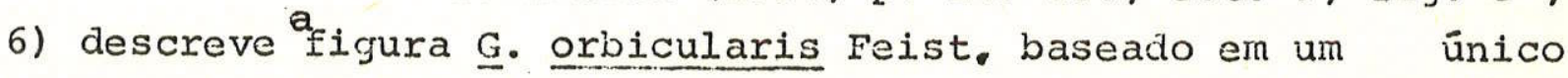
exemplar coletado pelo Dr. Euzébio de Oliveira em Teixeira Soares. Essa forma evidentemente é bern distinta em relação a $\underline{\text { G }}$ communis.

O importante trabalho apresentado por Rigby (1970), como já foi discutido, no que se refere aos fósseis do Parană, está baseado principalnente, em uma criteriosa revisão bibliográfica. Possuindo agora, o naterial coletado recentemen te naquele Estado, devemos reestudar as citações de Rigìy ( op. cit.). Nas três listas apresentadas por esse autor para as diferentes localidades paranacnses, encontramos as seguintes espé cies de Glossopteris:

G. browniana Brogniart - Ocorr.: Teixeira Soa res - Baseado na lista de Oliveira (1927, p. 73) .

G. Comnunis Feistmantel - Ocorr.: Teixeira So ares, Carbuí, Rio Carvãozinho e Barra Bonita - Baseado em espécies estudacias 
por Lundqvist (1919), Oliveira (1927) e Read (1941):

G. occidentales White - Ocorr.: Teixeira Soares - Baseado na lista de Oliveira (1927, p. 73) .

Glossopteris sp., cf. G. ampla - "Ocorr.: Cam buí" - B̧aseado em Read (1941). Glossopteris sp.

Vemos portanto, pelas cinco espécies acima lis tadas, apenas uma (G. communis) pôde ser revista por Rigby (op. cit.) com base ern descrição e figuras dos exemplares paranaenses. G. browniana e G. occidentalis, baseiam-se apenas na lista de oli veira (1927). Glossopteris sp. cf. G. ampla, como vimos anteri ormente, baseia-se em Read (1941), que se referia a um exemplar procedente de Santa Catarina. Na lista apresentada por Rigby (op. cit.) dos fósseis vegetais de Teixeira Soares, não aparece G. orbicularis, cuja ocorrência foi descrita por Dolianiti(1954). Apesar de não estar incluída naquela lista, essa espécie aparece assinalada acima na mesma página, (Rigby, 1970, p. 576), sem discussão ou sinonỉmia. Preferimos nanter essa espécie em,nossa lista, por estar ela, descrita e figurada, sendo ainda bastan te distinta do material por nós estudado. Rigby (op. cit.) con siderou, os espécines paranaenses anteriormente descritos como G. indica, pertencentes a espécie G. cominunis, o que nos parece bastante adequadio. De fato, a coleção por nós estudada e aqui descrita, é comparável com muitos dos exemplares figurados e de nominados de $\underline{G}$. indica nos trabalios anteriores acima citados. Deve ser aqui lembrado, que a espécie G. communis, proposta por Feistmantel em 1876, foi considerada em sinonimia com G. indica por zeiller (1396). Realmente, a nervação secundária de $\underline{G}$. communis apresenta uma variação, pela qual algumas formas se apresentain muito semelhantes a $\mathrm{G}$. inaica. Por esse motivo, zeiller (op. cit.) considerou as formas descritas como G. communis, variações intraespecíficas de G. indica. Arber (1905) concordou con essa sinonínia.

Somente em 1955, G. communis foi revalidada através de estudos com base nos caracteres da frutificação, por Sen (cf. Rigby, 1966). No ano seguinte Srivastava apresenta um reestudo dos gêneros de glossopterícieas, no qual analisa vārias espécies do gênero Glossopteris com base em caracteres cuticula res, comparando-os a caracteres morfológicos. Nesse estudo, 
Srivastava conclui que os caracteres cuticulares de G. indica são distintos dos de $G$. communis, sue, sob esse aspecto, se apro ximam mais de $\mathrm{G}$. browniana, que com aqucla espécie.

Bstudos cuticulares ainda não puderam ser rea lizados em Glossopterideas sul americanas. Entretanto, como apontou Oliveira $(1969$, p. 2) as correlações obtidas na Inäia, entre os caracteres cuticulares e os morfogräficos, permitem conclusões com base, exclusivamente, na morfografia.

Coin base no estucio desses caracteres morfográ ficos verificamos qué os espécimes por nós estudados realmente pertencem a espécie G. comrunis. n existência, em alguns exemplares, de malhas mais largas junto à nervura mediana, faz com que se pareçam con G. inaica, porén essas nalhas são sernpre mais alongadas que as dessa ültina espēcie.

G. Colmunis tern una vasta distribuição horizon tal. Alërn de no Estado do Paranā, é encontrada: no afloramento da subida do Bainha (Criciūna - S.C.) onde, segundo oliveira (op. cit., p. 20) é a espécie melhor representada guantitativamente. Segundo Rigby (1970) essa espécie ocorre ainda na localidacie de Treviso (S.C.), no sub-grupo Guatā, e nas seguintes localida des do Estado do Rio Grancie do Sul: Acampamento Velho, no subgrupo Itararé, e Arroio dos Cachorros no sub-grupo Guatá.

Segundo Menendez (1966 p. 17), G. Communis

ocorre na Argentina en duas regiões: Na província de Buenos Aires, Sierra de Pillaisuincó, Serie Bonete, e na província de La Rioja, Arroyo Totoral, estratos de Totoral (Paganzo II), ambas as ocorrências em canadas de idade permiano inferior.

Wuitas são as referências sobre a presença de G. comunis na India (Talchir, Karharbari, Barakar e Raniganj). Segundo Rigby (1970), essa espécie ocorre tanbēm na Austrália (Newcastle Coal Heasures - Upper Bowen Series).

c. Material estudacio - Todo material estudado foi coletado pelo autor. Compreencie formas preservadas sob for ma de impressão, al gumas de folinas quase completas. Procede de duas localidades: Cambuí e São Joño do Triunfo.

Material procedente de Cambuí: C37, C 40 e C90. Haterial procedente de São João do Triunfo: T2A, T8, T85A, T120, T163, T167, T169A, T169B, T200 e T205. 


\section{1 - CONIFEROPHYTA}

Classe Coniferopsida, ordem -Coniferales

De um modo geral, é pequeno o número de formas de coniferas reconhecidas nas camadas permianas, ou mesmo neopaleozóicas, da América do Sul. Alēm disso, apenas umas pou cas dentre essas, são bem, ou razoavelmente, conhecidas.

As formas de coniferas que ocorrem nas camadas permianas do continente sul americano conforme anālise crítica dos trabalhos de Archangelsky et Arrondo (1969), Arrondo (1972), Dolianiti (1972), Menendez (1966), Millan (1965, 1967 e 1972), Rigby (1970 e 1972) e Yoshida (1972), excluindo as madeiras fósseis, são as seguintes:

**Buriadia heterophylla (Feistmantel) Seward et Sahni

? Buriadia heterophylla (Feistmantel) Seward et Sahni

*? Buriadia sp.

Ginkgoites eximia

Ginkgoites patagonica

* Kräuselcladus catarinensis Yoshida

* Kräuselcladus canoinhensis Yoshida

**Paranocladus dusenii Florin

**Paranocladus ? fallax Florin

Paranocladus halii

*Paranocladus sp.

? Voltzia heterophylla (Buriadia heterophylla)

**Cordaicarpus (várias espécies)

*Samaropsis (vărias espécies) 


\title{
*Walikalia millanii Rigby
}

* Ocorre nas camadas Permianas da Bacia do Paraná.

** Ocorre nas camadas da Formação Rio Bonito, no Estado do Paranā.

A lista acima engloba oito diferentes gêneros, dos quais três estão representados nas camadas consideradas no presente estudo: Paranocladus, Buriadia e Cordaicarpus.

\author{
Gênero PARANOCLADUS Florin, 1940 \\ Est. 2, fig. 10 e 11 \\ Florin (1940, p. 319-322) ao instituir o
} gênero Paranocladus baseou-se nos exemplares de sua espécie ti-

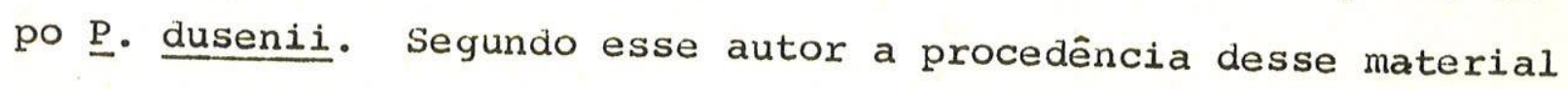
seria a localidade de Irati. Dolianiti (1952) retificou essa informação, considerando à localidade correta, como sendo Teixeira Soares. Florin (op. cit.) conseguiu realizar estudos cuticulares nesses espécimes e o gênero se baseia principalmente nas características epidérmicas. Infelizmente não encontramos exemplares dessa espécie em nenhum dos afloramentos estudados.

Descreveu tambëm aquele autor, em sua monu mental obra, a espécie $\underline{p}$. ? fallax. Essa espēcie foi baseada em aspectos morfogräficos, uma vez que o material de que dispunha Florin não apresentava possibilidade para estudos cuticulares. Por esse motivo florin (1940) preferiu manter essa espécie como dubiamente inclusa no gênero paranocladus. Trabalnando na área de onde procedia o material de $\underline{\text { p. }}$ ? fallax (Localida de "Patrimônio". - região de Cambuí) encontramos grande nümero 
de formas que morfograficamente corresponden àquela espëcie. (Est. 2, fig. 10 e 11). Esse material è quase sempre muito fragmentärio. Apesar disso, apresenta grande importância, pois aplicando técnicas sugeridas pelo Dr. S. Archangelsky, do Museo de La Plata, conseguimos, nuito recentemente, obter cuticulas em que alguns detalhes celulares da epiderme podem ser estudados. Dada a abundância de fragmentos coletados naqueles aflora mentos, novas tentativas, com aprimoramento das tēcnicas emprega das em relação ao tipo de material, sern düvida permitirão estudos detalhados da estrutura epidērmica. As observações prelimi nares dessas cutículas sugerem que $\underline{p}$. ? $\underline{\text { fallax }}$, realmente se di ferencie de $\underline{\text { p. dusenii. }}$

gênero BURIADIA Seward et Sami, 1920 emend, pant et Nautiyal, 1967

Este gênero compreende as formas brasileiras antes descritas como Voltzia, entre as quais Voltzia sp. de Tei xeira Soares, conforme estudo de Florin (1940), que as considerou como Buriadia heteropnylla Seward et Sahni, 1920.Read (1941 p. 92, est. 5, fig. 7) cita a ocorrência de um ünico exemplar na região de Cambuí, denominando-o Buriacia sp. Não possuímos em nossas coleções material semelhante. 


\title{
Sementes incertae sedis \\ gênero CORDAICARPUS Geinitz, 1862
}

\begin{abstract}
A ocorrência de sementes na localidade de "Patrimônio" (Cambuí) tem sido assinalada por vārios autores. Millan (1965) apresenta um estudo sobre as sementes do Carbonifero do Brasil, no qual revê os trabalhos anteriores referentes ao assunto. As citações de sementes fósseis feitas naquela 1ocalidade, são compreendidas por Millan (op. cit.), como Cordaicarpus sp. Nenhum trabalho mais recente versa sobre novas ocor rências de sementes fósseis no Estado do Paraná.
\end{abstract}

Pelo exposto, vemos que Cordaicarpus sp., cons titui a única forma de sementes fósseis conheciala na Formação Rio Bonito naquele Estado. Além disso, a única localidade em que sua ocorrência é conhecida, situa-se na região de cambuí.

Alguns poucos exemplares mal conservados que possuímos procedentes daquela localidade, constituem também os únicos que obtivemos em nossas coletas nos diferentes afloramen tos da Formação Rio Bonito, no Paranā. Alguns se parecem com Cordaicarpus nitens. Serão necessārias porém, novas e pacientes coletas, para proporcionar a possibilidade de um estudo mais conclusivo. 


\section{VIII - AMBIENTE DE DEPOSIÇÃO DA CAMADA FOSSILIFERA}

As diferentes estruturas sedimentares observadas nos arenitos basais da Formação Rio Bonito, como a típica estratificação cruzada, estruturas de canais, etc.,sugerem um ambiente de deposição do tipo fluvial deltāico. Essa idéia tem sido já manifestada por diferentes autores (Ver a parte: Informação Geológica, neste trabalho). Aceitamos tal idéia que nos parece perfeitamente de acordo com nossas observações de campo.

A intercalação das camadas de sedimentos geralmente mais finos, contendo camadas de carvão quase não tem sido discutidas com detalhes, sob o ponto de vista genētico. Em realidade, o único trabalho sobre o assunto é o de Leinz (1940). Esse autor considerou duas bacias hulheiferas, Barra Bonita (Ibaiti) e Rio Carvãozinho, chegando, entre outas, às conclusões aqui resumidas:

1. Essas jazidas são autōctones.

2. A gênese do carvão da bacia do Rio Carvãozinho teria dependido das seguintes fases:

A - Formação da depressão morfológica por ação das águas de degelo.

B - Formação do lago nas pequenas depres sões. A força dos tributários teria sido reduzida. 
C - Formação do pântano, com precipitação de calcário. Os vegetais progressivamente penetraram no lago. o pântano teria crescido até atingir a espessura de cerca de $20 \mathrm{~m}$. O pânta no estagnou-se devido à estabilidade tectônica da região. A turfa passaria a ser coberta por areia.

D - Diagênese do carvã̀o.

Atualmente a bacia do Rio Carvãozinho não apresenta mais as mesmas condições de estudo, de tal forma que as observações de Leinz (op. cit.) e as de outros autores, são muito importantes.

Para a sequência observada na ārea de são João do Triunfo, conforme mostra a coluna da fig. 6, propomos a seguinte interpretação, como hipōtese a ser testada:

1. Progressivamente os sedimentos deltáicos depositados na região paleogeograficamen te litorânea (durante o Permiano Inferior) passariam a cobrir os sedimentos do Folhelho Passinho, de origem marinha.

2. Os sedimentos de origem fluvial cobririam uma extensa ârea daquela região.

3. Dentro desse conjunto, a senilidade dos rios formariam ocasionalmente subambientes de sedimentação (meandros abandonados, áreas palustres marginais, etc.). 
4. Nesses subambientes se desenvolveria uma vegetação, que talvez, com eventual contribuição alóctone, forneceu elementos que hoje constituem as finas camadas de carvão.

5. Com o incremento da deposição de sedimentos, restos alóctones passariam a ser precipitados por sobre aquela camada de carvão (turfa). Notamos uma distribuição preferencial de impressões de troncos de licófitas no nível D (Fig. 6). Já no nível B essas não foram encontradas , predominando aí os fragmentos de felicineas. Ao nivel A, parece haver maior quantidade de folhas do tipo Glossopteris. Unindo esses dados à litologia, ve rificamos que o aumento de energia das āguas foi gradativo em direção ao topo da camada fossilifera. A orientação dos fósseis alongados se dispõe preferencial mente conforme direção N30: a N40\%, em le vantamento preliminar.

6. Finalmente por sobre esses sedimentos se depositaram outros semelhantes aos da ba se, possivelmente significando o retorno às mesmas condições deposicionais.

Essa mesma hipótese pode ser aplicável à região de Teixeira Soares e mais ao norte, até proximidades de Harmonia. Máis para o norte e nordeste o Folhelho Passinho já não aparece (Ver coluna na fig. 7). Pode ele ter sido erodido 
antes da deposição dos arenitos. E possivel tambēm que a ingressão maxinha não tenha atingido aquela região, e nesse caso, tal folhelho não teria jamais se depositado ali. A hipötese ex posta acima não tenta invalidar as interpretações de Leinz (1940). Em realidade nos faltam ainda maior quantidade de dados sobre essa ärea. 


\section{X - CORRELAÇÃO ENTRE AS OCORRENCIAS DO PARANA}

Ao se tentar estabelecer correlações entre camadas fossiliferas formadas em ambiente continental deve-se proceder com extrema cautela. Em primeiro lugar, deve-se levar em conta o fato de que os diferentes locais de deposição podem se constituir em vārias bacias distintas. Pode não haver portan to, uma correspondência física lateral, o que pode implicar, ou não, em diferenças de ordem cronolögica. Por outro lado, a correspondência cronológica não existe necessariamente, em se verificando a citada correspondência física, ainda que contínua e ma peável.

Outro aspecto importante a ser considerado principalmente no caso de correlações realizadas com base em fós seis vegetais, é o conjunto de variações devido a fatores paleoecológicos. Os vegetais apresentam em geral uma dependência mesológica acentuada. Em consequência desse fato, diferentes associações florísticas bem individualizadas, podem ser encontradas numa mesma região dentro da qual existam,em diferentes āreas, condições ambientais consideravelmente distintas. O clima, topografia, solo, quantidade de āgua sob forma líquida, entre outros são fatores que podem influir decisivamente na composição da associação florística.

No caso de floras antigas, e principalmente as paleozóicas, o problema se torna delicado. Isso acontece principalmente porque não conhecemos ainda o suficiente sobre a paleoecologia de seus componentes. Além disso, os fósseis coletados em um afloramento, possivelmente representam uma amostra muito parcial da realidade paleoflorística. 
Em terceiro lugar, ao se utilizar elementos alōctones para a correlação, deve-se levar em conta a seleção dos fragmentos de diferentes formas durante o transporte e deposição. Devido a esse mecanismo, afloramentos de camadas cujo se dimentos se depositaram dentro de um mesmo lapso de tempo podem apresentar um conjunto de fösseis bastante distinto.

A distribuição das diferentes formas de fōsseis vegetais na Formação Rio Bonito no Estado do Paranā, estã representada na tabela 7. Vemos que existe uma relativa coincidência sob esse aspecto, entre as localidades de Cambuí e S.João do Triunfo. Das 15 formas representadas num, ou noutro afloramento, 8 são comuns a ambos. Em São João do Triunfo é notável - fato de não termos encontrado restos de coníferas em nenhum dos níveis e locais examinados. Em Cambuí, fragmentos de paranocladus, embora geralmente mal conservados, são comuns. A ausência de megásporos em Cambuí pode ser aparente pois os sedimentos da matriz não os destacam tão nitidamente como acontece em S. João do Triunfo.

Rio Carvãozinho, Ibaiti e Teixeira Soares apresentam menor quantidade de formas. Vemos, ainda na Tabela 7 , que nenhuma forma, que ocorre nas duas primeiras localidades, é exclusiva das mesmas. Com relação à Teixeira Soares, apenas $\underline{G}$. orbicularis não foi encontrada nas outras localidades. Lembramos que, até hoje apenas um exemplar é conhecido, dessa espécie, em T. Soares.

Quantitativamente porém, as diferenças pare cem ser um pouco maiores. As licófitas parecem ser os elementos mais abundantes em Cambuỉ, enquanto que em S. João do Triunfo são mais raras. Daỉ possuímos apenas pouco exemplares. Por outro 
lado, nessa localidade as felicíneas são extremamente mais abundantes que em Cambuí. Outra dírerença, como já dissemos, se refere às coníferas, ausentes em S. João do Triunfo.

Que significado podem ter essas diferenças? Lembrando das considerações iniciais, tentaremos interpretā-las. As licófitas que ocorrem em S. João do Triunfo, como nos referimos ao discutirmos o ambiente de deposição, são mais abundantes na capa da camada de carvão. São muito raras nos níveis A e B (fig. 6). Não sabemos se essa posição é vālida tambēm para outras localidades. Porém lembramos o fato de que em Cambuí, cole tamos nosso material do interior das galerias das minas. Portanto todo aquele material corresponde às camadas que se sobrepõe imediatamente à camada de carvão, numa área relativamente extensa. Isso naturalmente nos fornece uma amostragem válida, apenas para esses niveis. Lembramos ainda, que na discussão sobre o am biente, admitimos a possibilidade de ter havido, no caso de $\mathrm{s}$. João do Triunfo, uma deposição seletiva, que se alterou com o transcorrer da história deposicional daquelas camadas fossiliferas.

Com relação às felicíneas, que em Cambuí parecem ocorrer em menor quantidade, o mesmo motivo acima apontado pode ser a causa. De fato, em S. João do Triunfo, a maior quantidade de restos de felicíneas foi encontrado na parte média da camada (entre A e C, fig. 6). E importante também o fato de que os sedimentos da matriz em Cambuí não contêm, em geral, impressões de formas mais delicadas, sendo que, em s. João do Triunfo as impressões são frequentemente muito boas. Esse fato pode cau sar também uma diferença aparente na composiçäo da flōrula de cạ da localidade. 
a interpretação è mais difícil. Apesar da boa qualidade da matriz em S. João do Triunfo, essas coniferas não foram atē agora aỉ encontradas. A primeira hipōtese que surge à mente, é sobre a existência de uma diferença ambiental, a ponto de condicionar diferenças quanto à representação numérica de cada forma, na composição geral. As diferenças ambientais poderiam ser, em parte, de ordem climātica, que por sua vez poderia ter, ou não, implicações quanto a interpretações sobre topografia. Uma maior altitude da paleosuperfície poderia explicar a ausência do Folhelho Passinho na ārea mais ao norte do Estado. A menor quantidade de felicineas nesses afloramentos poderia ser tambëm lembrada.

Devemos ponderax porém, que atē hoje nenhum tronco fössil de conífera foi encontrado nesses afloramentos. As coniferas são conhecidas em Cambui apenas por fragmentos de ramos distais, e sua determinação ainda não é segura. Por outro lado, Paxanocladus dusenii que Florin descreveu em 1940, citando a localidade como Irati, seria procedente de T. Soares, segundo Dolianiti (1952). Essa localidade é bastante próxima de são João do Triunfo e como vimos (Ver: Afloramentos estudados) o Folhelho Passinho ocor re abaixo dessas camadas.

Acreditamos ser ainda precoce qualquer interpretação mais elaborada sobre as diferenças na composição das paleofloras nas difexentes localidades citadas. De um modo geral, podemos dizer que essas flórulas se assemelham mais entre si, que com outras da Bacia do Paraná. 


\section{$X$ - COMPARAÇÕES COM OUTRAS OCORRENCIAS}

\section{1 - Bacia do Paraná}

Ao que parecè, não existe muita relação da flo ra aqui estudada com as raras ocorrências em camadas do Subgrupo Itararē (Ver tab. 8). Na flora de Monte Mor (S.P.), recentemente estudada por Millan, encontramos apenas 4 formas das 17 do Paraná. Dentre essas 4, Paracalamites australis não apresenta maior valor bioestratigráfico, e Lycopodiopsis pedroanus parece tambēm não ser um indicador muito seguro. Acreditamos que a flórula de Monte Mor e aquelas aqui tratadas, constituem dois conjuntos distintos.

Comparando com outras ocorrências da Formação Rio Bonito (Ver tab. 9), excluindo paracalamites australis, as re lações são pequenas. A Formação Estrada Nova, por sua vez, possui um conjunto de fósseis vegetais bastante distinto dos aqui tratados (Ver tab. 10).

\section{2 - Outras bacias}

E pequena a relação dessa flora com as das ida des Tupense e Trampeaderense (Carbonifero) da Argentina. Comparando porém com 10 localidades fitofossilíferas do Permiano daque le pais, notamos que aquelas das Provincias de Chubut e Santa Cruz, na Patagônia, são as que apresentam maior relação com as nossas floras.

Comparações foram feitas ainda, com as ocorrên cias do Carbonifero Superior e do Permiano Inferior da India. Es- 
sas floras da India, assim como as da Austrália não parecem estar muito relacionadas com as do Paranā; Não fosse a existência, aqui e lá, das espécies Glossopteris communis e Paracalamites australis, além de G. obovata (na Austrália) e Buriadia heterophylla (na India), inexistiria elementos de comparação.

A flora aqui-tratada, portanto, se constitui numa unidade paleofloristica e somente parece apresentar afinidades maiores com as floras do Permiano da Patagônia. Essas tem em comum com as do Paraná as seguintes formas:

Lycopodiopsis pedroanus (Carruthers) Edwards

Paracalamites australis Rigby

Asterotheca cambuhyensis (Read)

? Sphenopteris lobifolia Morris

Glossopteris communis Feistmantel

Gangamopteris obovata Feistmantel

Paranocladus sp.

Alēm das formas altamente prōximas morfologicamente:

Paraná Patagônia

Annularia readi .................. kurzii Arch.

Asterotheca derbyi ........... feruglioi Freng

Possui ainda outras, que são aparentadas genericamente.

Na representação porcentual das diferentes for mas, existe também uma impressionante coincidência entre o Paraná e Patagônia.

Além disso, a associação do Paranā apresenta vārias formas não restritas ao Gondwana, como: Sphenophyllum, Annülaria, Asterotheca, Sphenopteris e Pecopteris. Esses gêneros são comuns nas camadas neopaleozóicas do hemisfério norte. Como 
na Patagônia ocorrem também estas formas, cujos ancestrais não são conhecidos nas camadas mais antigas, é possivel que tenham mi grado para lá. A região paranaense considerada, e sua flora, podem se constituir num dos elos dessa corrente migratöria.

Asama (1966) tem refutado as idëias sobre as migrações, considerando a presença de formas permianas do Gondwana, nas regiões da Cataysia e Angara. Asama (op. cit.) tenta explicar a presença dessas formas naquelas regiões atravës da Homoplasia.

No caso de nossas asterotecáceas, a semelhança com as formas do hemisfërio norte vão muito alēm da simples aparência das folhas (Vide fig. 21). 


$$
X I-I D A D E
$$

A associação de fósseis vegetais encontrada na Formação Rio Bonito no Estado do Paranā não se confunde com outras situadas em níveis estratigráficos diferentes na Bacia do Pa raná. Por outro lado, apresenta grande semelhança a associação encontrada na Patagônia, correspondente ao Lubeckense A.

Na Argentina a seguinte distribuição e relação das idades è proposta por Archangelsky (1971, p. 82), com base em fósseis vegetais:

\begin{tabular}{|c|c|c|c|}
\hline SISTEMA & SERIE & ANDAR & $\begin{array}{c}\text { IDADES } \\
\text { ARGENTINAS }\end{array}$ \\
\hline \multirow{5}{*}{ Permiano } & \multirow{2}{*}{ Superior } & Tartariano & \multirow{3}{*}{ 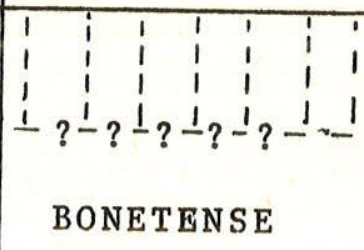 } \\
\hline & & Kazaniano & \\
\hline & \multirow{3}{*}{ Inferior } & Kunguriano & \\
\hline & & Artinskiano & \multirow{2}{*}{$A^{B}$ LUBECKENSE } \\
\hline & & Sakmariano & \\
\hline \multirow{5}{*}{ Carbonífero } & Stefaniano & $\begin{array}{l}\mathrm{C} \\
\mathrm{B} \\
\mathrm{A}\end{array}$ & $\begin{array}{c}\text { TRAMPEADERENSE } \\
?\end{array}$ \\
\hline & Westfaliano & $\begin{array}{l}\text { D } \\
\text { C } \\
\text { B } \\
\text { A }\end{array}$ & \multirow{2}{*}{ 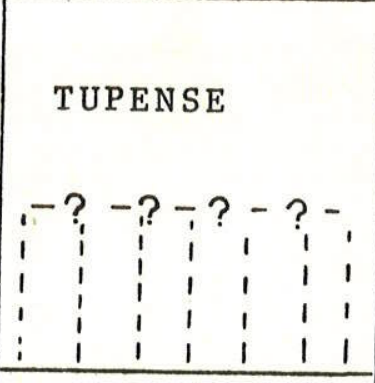 } \\
\hline & Namuriano & $\begin{array}{l}\mathrm{C} \\
\mathrm{B} \\
\mathrm{A}\end{array}$ & \\
\hline & \multirow{2}{*}{ Inferior } & Visiano & MAL IMANENSE \\
\hline & & Turnasiano & $\begin{array}{llllllll} & & & & 1 & 1 & 1 & 1 \\
1 & & & & 1 & 1 & 1 & 1 \\
\end{array}$ \\
\hline
\end{tabular}


Vemos que o limite Carbonĭfero/Permiano não está totalmente estabelecido, porëm tem sido bem aceita por diferentes autores, a idade Permiano Inferior para o Lubeckense. Tal idade para a flora do Paranā aqui estudada, concorda com a indicada através de fósseis marinhos (Qriocrassatella, Myonia, Heteropecten, etc.) encontrados na Formação Rio Bonito em Santa Catarina, que segundo Rocha-Campos (1967 e 1969) seriam do Permiano Inferior.

Essa idade entretanto não concorda com resultados dos estudos palinológicos de Daemon et Quadros (1969) que sugerem para a Formação Rio Bonito, uma idade Permiano supe rior.

Baseado nas mesmas correlações verificamos que as jazidas de Monte Mor seriam mais antigas que as do Paranä, conclusão aliās a que chegou Millian (1972). Com relação às jazidas catarinenses nos parecem no conjunto, mais facilmente correlacionáveis com o Lubeckense $B$. Nesse caso, seriam um pou co mais recentes que aquelas do paraná. A título de esquema a ser testado nas próximas investigações, sugerimos o seguintè esquema para a posição cronológica dessa ocorrência:

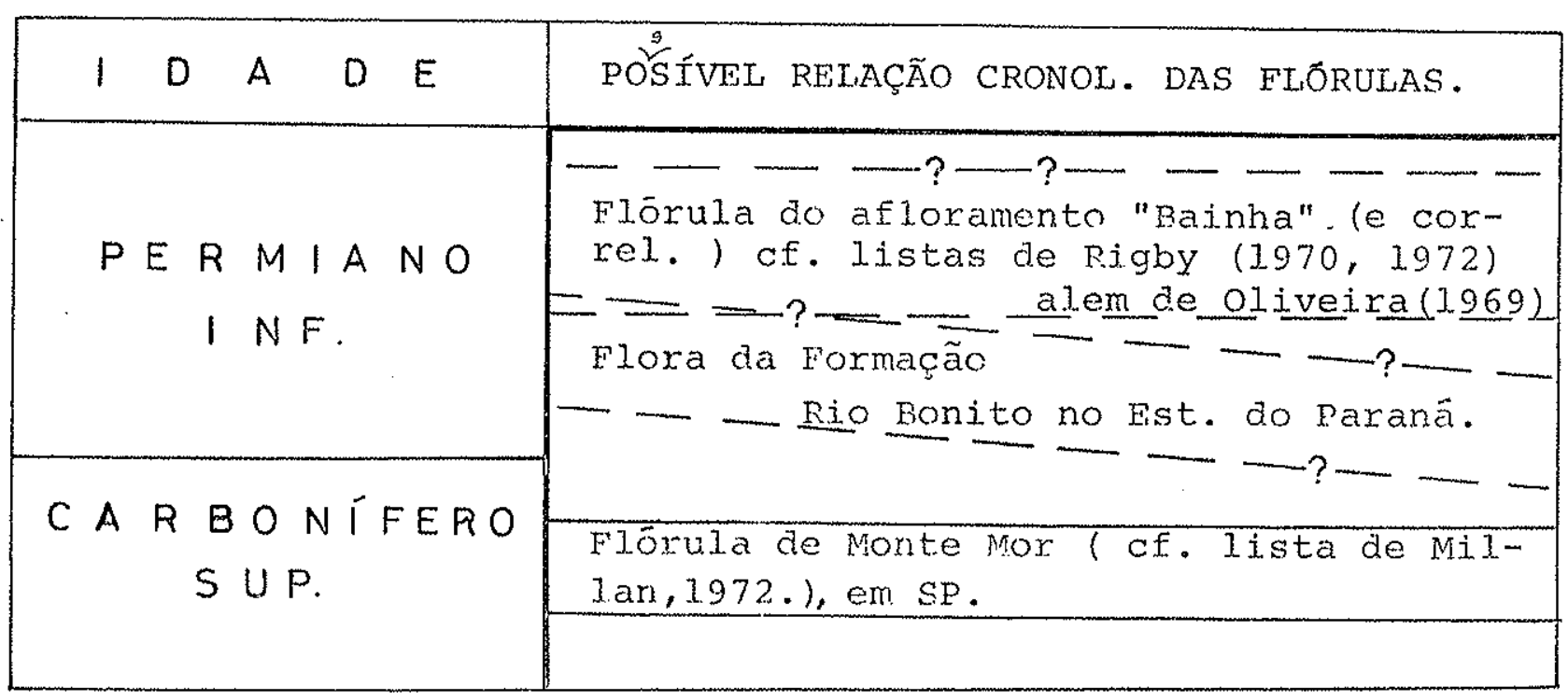




$$
X I 1-C O N C L U S O E S
$$

1. A flora da Formação Rio Bonito no Estado do Paranä constitui uma unidade floristica distinta das demais associações conhecidas na Bacia do paraná.

2. Entre todas as ocorrências gondwânicas, essa associação mais se aproxima das floras permianas da Patagônia.

3. E provāvel que em base dessas comparações tenha a base dessa formação idade permiana inferior.

4. São quase predominantes numericamente os exemplares de formas "nördicas", entre as quais Asterotheca, Annularia e Sphenophyl1.um.

5. As correlações feitas entre o que se conhece de cada uma das principais floras de SP, Pr, e SC (Flörula Monte Mor, Flora da Formação Rio Bonito no Paraná e Flórula do Bainha e suas correlatas) com as demais floras gondwânicas (principalmente da Argentina) sugerem que a Flora da Formação Rio Bonito é mais recente que a de Monte Mor, porém em parte, talvez mais antiga que a de Bainha e correlatas.

6. As camadas fossiliferas e o carvão na região de são João do Triunfo provavelmente se formaxam em subambientes fluviais deltáicos.

7. As diferenças observadas na distribuição vertical dos fósseis vegetais nessas camadas, são provavelmente devidas à seleção diferencial durante transporte e deposição.

8. A região ocupada por essa flora pode ter integrado uma faixa de fluxo migratōrio das formas nördicas para o extremo sul (re gião patagônica). 


\section{Tabela 1 - Asterotheca derbyj - medidas e observações nas frondes fërteis. $(\mathrm{m} / \mathrm{m})$}

1 - Colunas

I - Pinação do fragmento: Monopinado (MON)

$$
\text { Bipinado (BIP) }
$$

II - Largura do ráquis do segmento maior.

III - Angulo formado entre as pinas e ráquis maior.

IV - Comprimento das pinas.

V - Largura geral das pinas.

VI - Largura máxima das pinas.

VII - Largura do ráquis das pinas.

VIII a X - Distâncias medidas entre duas pinulas consecutivas em três nỉveis:

$$
\begin{aligned}
& \text { VIII - nivel da base } \\
& \text { IX - nivel mëdio } \\
& \text { X - medido a um mm abaixo dos ápices }
\end{aligned}
$$

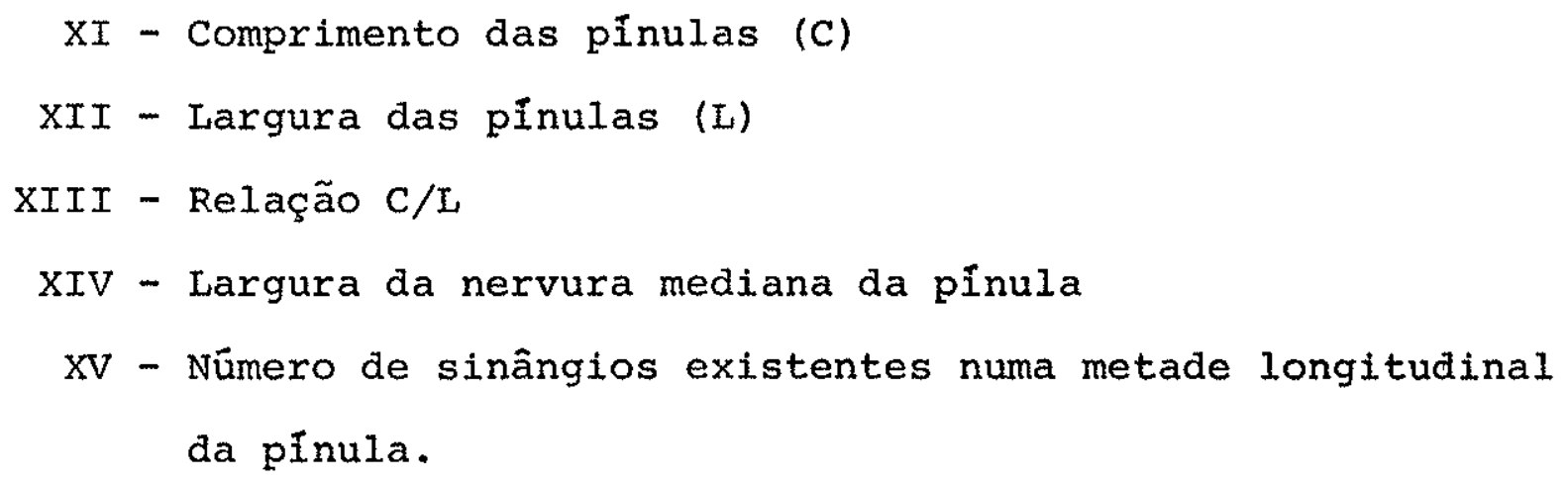
da pinula.

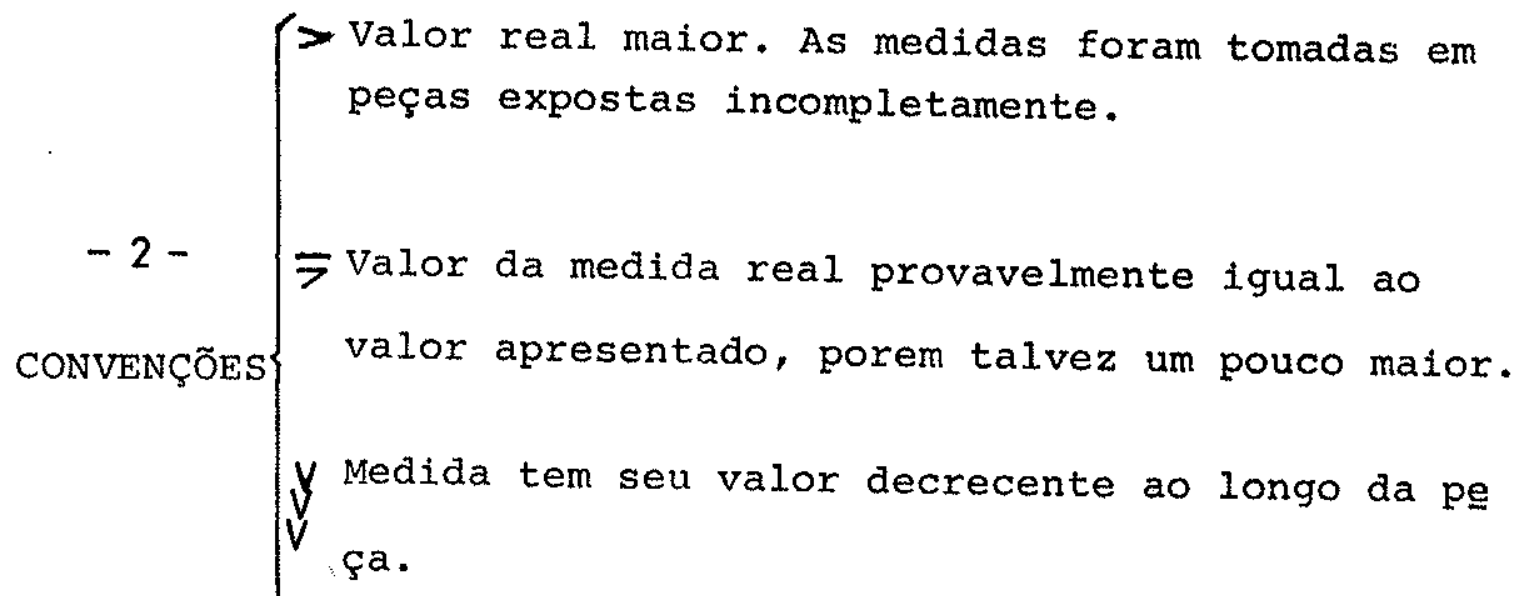


TABELA 1 I

T 37

2410

T112*

T112* *

T181

T 80

B I P

BIP

PID
II

B I P

5,0

5,0

$60^{\circ}$

709

609

$>65$

700
VI

18,0

VII

$609>60,00$

$16,0-18,0$

15,0

15,0

1,9

$60 \%-80,0$

15,0

15,5

$1: \frac{3}{6}$
$1 ; 9$

$70990^{\circ} \cdot>47,0$

11,0

12,0

1., 2

1,2

1,4

12,0

13,0

1,7

1,4

$16,0-$

$>25,0$

1,5 
ASTEROTHECA DERBYI (frondes férteis)

\begin{tabular}{|c|c|c|c|c|c|c|c|c|}
\hline & VIII & $I X$ & $\mathrm{x}$ & $X I$ & $X I I$ & XIII & $X I V$ & $X V$ \\
\hline \multirow{3}{*}{ T 37} & 1,0 & 1,0 & 2,0 & 7,0 & 2,8 & 2,5 & 0,4 & - \\
\hline & 1,0 & 1,0 & 2,0 & 9,5 & 3,5 & 2,7 & - & - \\
\hline & 0,0 & 0,3 & - & - & - & - & - & - \\
\hline \multirow[t]{5}{*}{ T410 } & 0,0 & 0,0 & $<1,0$ & 6,8 & 3,3 & 2,1 & 0,3 & $>_{6}$ \\
\hline & 0,0 & 0,3 & $<1,0$ & 6,8 & 3,8 & 1,8 & 0,4 & $>6$ \\
\hline & 0,0 & 0.2 & $<1,0$ & 7,0 & 3,3 & 2,1 & 0,3 & $>_{6}$ \\
\hline & 0,0 & 0,3 & $<1,0$ & 7,2 & 3,6 & 2,0 & 0,4 & $>6$ \\
\hline & 0,0 & 0,4 & $\because 1,0$ & 8,0 & 3,6 & 2,2 & 0,3 & $>6$ \\
\hline \multirow[t]{3}{*}{ T112* } & 0,0 & 0,0 & $<1,0$ & 7.0 & 4,0 & 1,8 & - & \\
\hline & 0,0 & 0,0 & $<1,0$ & 8,2 & 4,0 & 2,0 & - & $>6$ \\
\hline & 0,0 & 0,0 & $<1,0$ & 6,7 & 3,7 & 1,8 & - & \\
\hline \multirow[t]{3}{*}{$\sin 2 * *$} & 0,0 & 0,0 & $1, n$ & 7,0 & 3,3 & 2,1 & - & - \\
\hline & 0,0 & 0,0 & 0,9 & 6,0 & 3,5 & 1,7 & - & - \\
\hline & 0,0 & 0,0 & 1,0 & 7,5 & 3,3 & 2,3 & - & - \\
\hline \multirow[t]{2}{*}{$\mathrm{T} 131$} & 0.0 & 0,0 & 0,3 & 7,0 & 4,0 & 1,7 & - & - \\
\hline & 0,0 & 0,3 & 0,3 & 7,0 & 4.0 & 1,7 & - & - \\
\hline \multirow[t]{2}{*}{ T 80} & 0,5 & 1,2 & 2,0 & - & 3,2 & - & 0,6 & $>11$ \\
\hline & & $\sim$ & & ' & & & 0,6 & $>6$ \\
\hline
\end{tabular}

* Medidas tomadas na porção proximal da fronde

** Međidas tomadas na porção distal da fronde 
CONTIN. DA TABELA 1

T 151

$+62$

T152

A

T 372

T 87

T 366
II

$\uparrow 3,5$

3,4

RIP

RIP

BIP

5,4
5,8

6,4

BIP

7,0

$60^{\circ}$

$70 \%$

$>45,0$

13,0

14,0

MON

IV

$>40,0$

12,0

$80 \%$

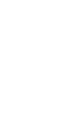

14,0

11,0

15,0

12,0

1,0

$>16,0$

1,6 
VIII

IX

XI

XII

XIII

XIV

$\mathrm{T} 151$

0,0

0,5

6,0

2,4

2,5

$->6$

$0,0,0$,

1,0

3,2

2,0

2,3

$>6$

T 62

0,0

0,0

$<1,0$

0,0

0,0

$<1,0$

5,3

I, 6

3,4

6,0

1,9

$\begin{array}{ll}- & >5 \\ - & >5\end{array}$

3,3

2,3

2, 2

2,5

2,7

2,7

$-$

0,0

1,0

5,0

2,8

7,3

2,8

3,0

0,2

0,5

1, 1

7,5

2,5

2,3

1,6

1., 8

2,6

$\begin{array}{ll}0,3 & >6 \\ 0,3 & >6 \\ 0,3 & >6 \\ 0,3 & >6\end{array}$

0,0

0,0

$<1,0$

5,7

3,4

6,4

3,5

6,7

2,6

6,5

3,0

2,2

2,3

3,0

2,0

$0,3>5$

$0,4>5$

$0,4>5$

$0,3 \equiv 5$

0,0
0,0

0,2

7,0

3,5

2,3

7,0
8,0

3,0
3,5

2,3

$0,4>6$

$0,4>6$

$0,4>6$

$\theta, 0$
0,0

0,5

1,0
1,0

$\begin{array}{ll}0,5 & >6 \\ 0,5 & >6\end{array}$ 
CONTIN. DA TABELA 1

I

II

III

IV

V

VI

VII

T377

MON

$>45,0$

19,0

1,3

$\mathrm{T} 144$

MON

$>40,0$

20,0

1,2

T 94

MON

MON

MON

30,0

20,0

18,0

1,0

T123

T. 358

MON

T 152

MON 
VIII

IX

X

XI

XII

$<1.0$

9,0

9,5

10,0

$<1,0$

0,0

0,2

$<1,0$

11,0

11,0

0,0

1,0

10,0

0,0

1,0

I, 5

10,0

1,0

0,5

1,0

1,0

1,5

0,0

0,0

0,0

0,4

$<1,0$

1,0

0,2

$<1,0$

0,0

0,3

1,0

0,2

0,2

0,2
0,0

0,0

0,0

$$
8,5
$$

8,5

7,0

10.0

8,0

6,5

7,0

1,0

1,0

7,5 .

$\begin{array}{ll}\mathrm{P} & 0,0 \\ & 0,0\end{array}$

XIII

XIV

XV

$3, n$

3,5

2,3

2,9

2, 2

2,6

3,1

3,0
3,0

3,4
0,4

10
2,2

2,3

2,2
0,3

0,3

0,3

0,3

0,4

0,4

0,2

0,2

0,4

0,4

$>6$

10

11

11

11

6
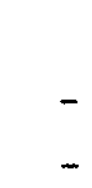

0,3

0,3

0,3 


\section{Tabela 2 - Asterotheca cambuhyensis - medidas e obser- vações das fxondes férteis.}

Colunas

I - Pinação do Eragmento: Monopinado (MON)

Bipinado (BIP)

II - Largura do räquis do segmento maior.

III - Angulo formado entre as pinas e ráquis maior.

IV - Comprimento das pinas.

$V$ - Largura geral das pinas.

VI - Largura mäxima das pinas.

VII - Largura do räquis das pinas.

VIII a X - Distâncias medidas entre duas pinulas consecutivas em três níveis:

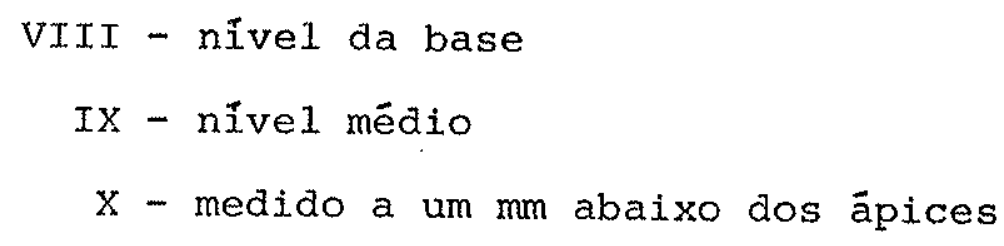

XI - Comprimento das pinulas (C)

XII - Largura das pinulas (L)

XIII - Relação C/L

XIV - Largura da nervura mediana da pinula

XV - Nümero de sinângios existentes numa metade longitudinal da pinula. 


\section{IIIOTHECA CAMBUHYENSIS (Frondes férteis)}

II

1,9

2, 2

80

PIP
BIP

BI

MON
3,0

$70^{\circ}$

$1,2 * *$

$\mathrm{V}$
8,0
9,0
10,0

VI

0,9

1,0

1,1

$45 \% \quad>20,0$

9,0

9,0

1,0

$>25,0$

8,0

8,0

1,0

$0,6 * \quad 70^{\circ}$

$8 \cap 9$
4,0

17,0

5,5

5,5

0,8 
ASTEROTHECA CAMBUHYENSIS (Frondes fërteis)

VIII

IX

$\mathrm{X}$

XI

XII

XIII

XIV

XV

0,0

0,0

0.0

3,5

2, 8

1, 2

0,4

3,5

I, 5

0,4

4

T 237

0,0

0.0

0,2

3,8

3, 2

3,2

1, 2

$-$

$-$

$$
0,0
$$

0,0

0,5

4,5

3,0

I, 3

1,5

$-$

3,0

2,9

1, 1

0,3

0,3

3,7

1, 4

0,3

$1, n$

2,3

2,8

2,5

1,1

1,4

0,3

0,3

0,3

T 35

0,0

0,0

$<0,5$

2,5

2.5

1,0

0.0

0,0

$<0,5$

0,0

$<0,5$

2,5

2,7

2,5

2,6

$1, n$

1,0 
Tabela 3 e 4 - Medidas e observações em frondes estéreis de Asterotheca (Em mm)

Tabela 3 - Asterotheca derbyi n. sp.

Tabela 4 - Asterotheca cambuhyensis

Coluna

1 - Pinação da fronde - Monopinada (MON)

Bipinada (BIP).

2 - Comprimento do fragmento de fronde

3 - Maior largura do fragmento de fronde

4 - Largura do ráquis do fragmento

5 - Largura do ráquis da pina

6 - Ângulo Pina/ráquis do fragmento.

7 - Comprimento das pinas

8 - Largura geral das pinas.

9 - Largura máxima das pinas

10 a 12 - Distância entre duas pinulas consecutivas medida em três níveis:

10 - nível da base

11 - nível médio

12 - a $1 \mathrm{~mm}$ abaixo dos ápices

13 - Comprimento das pínulas (C)

14 - Largura māxima das pínulas (L)

15 - Relação C/L

16 - Largura da nervura mediana da pinula

17 - Número de nervuras secundārias que partem da nervura mediana, antes da dicotomia, contadas numa metade longitudinal.

18 - Número de dicotomias das nervuras secundárias

19 - Distância entre nervura mediana e primeira dicotomia da nervura secundária

20 - Distância entre nervura mediana e a segunda dicotomia da nervura secundāria 


\begin{tabular}{|c|c|c|c|c|c|c|c|c|c|}
\hline TABELA & 3 & & TEROTHECA & BYI（ & des & éreis) & & & \\
\hline & 1 & 2 & 3 & 4 & 5 & 6 & 7 & 8 & 9 \\
\hline $\begin{array}{r}\text { T391 } \\
A\end{array}$ & $B I P$ & $>100,0$ & $>120,0$ & 4,0 & 3,2 & $609-809$ & $>80,0$ & $\Rightarrow>>$ & 20,0 \\
\hline T349 & MON & $>25,0$ & 20,0 & - & 2,3 & - & 25,0 & 20,0 & 20,0 \\
\hline T347 & BIP & $>45 ; 0$ & $>60,0$ & 5,0 & 2,8 & $709-809$ & $>50$ & $=>>$ & 20,0 \\
\hline T 389 & BIP & $>40,0$ & $>45,0$ & - & $\begin{array}{l}1,9 \\
1,3\end{array}$ & - & $\begin{array}{l}=30,0 \\
=30,0\end{array}$ & $\begin{array}{l}15,0 \\
15,0\end{array}$ & $\begin{array}{l}15,0 \\
15,0\end{array}$ \\
\hline C96A & $B I B$ & $>70,0$ & $>50,0$ & 8,0 & 2,3 & $70 \div-809$ & $=50,0$ & 26,0 & 26,0 \\
\hline
\end{tabular}


ASTEROTHECA DERBYT (Frondes estēreis)

\begin{tabular}{|c|c|c|c|c|c|c|c|c|c|c|c|}
\hline & 10 & 11 & 12 & 1.3 & 14 & 15 & 16 & 17 & 18 & 19 & 20 \\
\hline T 391 & 0,0 & 0,0 & 1,0 & 12,0 & 5,0 & 2,4 & 0,6 & 7 & $1-3$ & 0,5 & 1,1 \\
\hline \multirow[t]{5}{*}{$\lambda$} & 0.2 & 0,5 & 1,0 & 9,4 & 5,0 & 1,9 & 0,4 & 6 & $1-2$ & 0,5 & 1,1 \\
\hline & 0,0 & 0.5 & 1,0 & 6,0 & 4,1 & 1,5 & 0,5 & 6 & $1-2$ & - & - \\
\hline & 0,5 & 0,5 & 1.0 & 12,5 & 5.1 & 2,5 & 0,7 & 7 & $1-3$ & 0,4 & 1,1 \\
\hline & 0.3 & 0,5 & 1,0 & 9,5 & 4,2 & 2,3 & 0,7 & 5 & $1-2$ & - & - \\
\hline & 0,2 & 0,2 & $1, n$ & 5.6 & 3,5 & 1,6 & 0,6 & 6 & $1-2$ & - & - \\
\hline \multirow[t]{3}{*}{ T 349} & 0,3 & $n, 3$ & 1,0 & 7,0 & $3 ; 4$ & 2,1 & 0,5 & 6 & 2 & 0,5 & 1,6 \\
\hline & 0,3 & 0,3 & 1,0 & 7,4 & 3,7 & 2,0 & 0,7 & 7 & 2 & 0,5 & 1,4 \\
\hline & 0,3 & 0,3 & 1,0 & 7,4 & 3,7 & 2,0 & 0.6 & 6 & 2 & $n, 5$ & 1,4 \\
\hline \multirow[t]{3}{*}{$T 437$} & 0,0 & 0,0 & 1.0 & 9,0 & 4,2 & 2,1 & 0,4 & 6 & 2 & 0.4 & 1,4 \\
\hline & 0,0 & 0,6 & 1,0 & 7,8 & 3,3 & 2,4 & 0,4 & F & 2 & - & - \\
\hline & 0,5 & 0,5 & $1, n$ & 6.5 & 3,0 & 2,2 & 0,4 & 6 & 1 & $T$ & - \\
\hline \multirow[t]{2}{*}{ T380 } & $n, 0$ & 0,0 & 1,0 & 7,4 & 4,0 & 1,9 & 0,6 & 6 & 2 & 0,5 & 1,0 \\
\hline & 0,5 & 0,5 & 1,0 & 8,0 & 3,7 & 2,2 & 0,6 & 6 & 2 & 0,5 & 1,0 \\
\hline c. 96 & 0,0 & 0,0 & - & $>13,0$ & 5,0 & $>2,6$ & 0,5 & - & - & - & - \\
\hline
\end{tabular}


CONTIN. DA TABEIA 3

\begin{tabular}{|c|c|c|c|c|c|c|c|c|c|}
\hline & 1 & 2 & 3 & 4 & 5 & 6 & 7 & 8 & 9 \\
\hline \multirow[t]{3}{*}{ T 406} & BIP & $>30,0$ & $>35,5$ & - & 1,0 & - & $>35,0$ & $\Rightarrow$ & 12,0 \\
\hline & & & & & 1,3 & - & $=35,0$ & - & - \\
\hline & & & & & 1,5 & - & $>35,0$ & - & - \\
\hline T 353 & BIP & $>35,0$ & $>35,0$ & - & 1,4 & - & 36,0 & $=->$ & 12,0 \\
\hline \multirow[t]{4}{*}{$T 426$} & RIP & $>42,0$ & $>50,0$ & 30. & 1,2 & 709 & $>30,0$ & $>>$ & 12,0 \\
\hline & & & & & 1,2 & $70 \%$ & - & - & - \\
\hline & & & & & 1,3 & $70^{\circ}$ & - & - & - \\
\hline & & & & & 1,4 & $70 \%$ & - & - & - \\
\hline T157 & MON & $>50.0$ & $=17,0$ & - & 1,6 & - & $>50,0$ & $\rightarrow>$ & 17,0 \\
\hline
\end{tabular}




$\begin{array}{lllllllllll}10 & 11 & 12 & 13 & 14 & 15 & 16 & 17 & 18 & 19 & 20\end{array}$

$\begin{array}{rccccccccccc}\text { T406 } & 0,3 & 0,3 & 1,0 & 4,5 & 3,2 & 1,4 & 0,4 & 6 & 1 & - & - \\ 0,3 & 0,3 & 1,0 & 5,0 & 3,4 & 1,5 & 0,3 & 6 & 1 & 0,6 & - \\ - & - & - & 5,2 & 3,7 & 1,4 & 0,4 & 6 & 1 & 0,5 & - \\ - & - & - & 6,0 & 3,8 & 1,6 & - & - & - & 0,5 & - \\ - & - & - & 6,8 & 2,9 & 2,3 & - & - & - & - & -\end{array}$

\begin{tabular}{|c|c|c|c|c|c|c|c|c|c|c|}
\hline T353 & 0,5 & 0,5 & 1,0 & 6,5 & 3,5 & 1,9 & 0,4 & - & - & - \\
\hline & 0,3 & 0,3 & 1,0 & 5,0 & 3,5 & 1,5 & 0,3 & - & - & - \\
\hline & 0,0 & 0,0 & 1,0 & 4,0 & 2,5 & 1,6 & - & - & - & - \\
\hline T426 & 0,0 & 0,0 & 1,0 & 4,0 & 2,9 & 1,7 & - & - & - & - \\
\hline & 0,0 & 0,0 & 1,0 & 5,5 & 3,2 & 1,7 & - & - & - & - \\
\hline & 0,3 & 0,0 & 1,0 & 6,2 & 3,0 & 2,1 & - & - & 1 & - \\
\hline T157 & 0.0 & 0,0 & 1,0 & 6,5 & 4,5 & 1,9 & 0,5 & - & - & - \\
\hline & - & - & - & 7,0 & 5,0 & 1,4 & 0,5 & - & - & - \\
\hline & 0,3 & 0,3 & 1,0 & 9,0 & 5,8 & 1,6 & - & - & - & - \\
\hline
\end{tabular}


CONTIN. DA TABELA 3

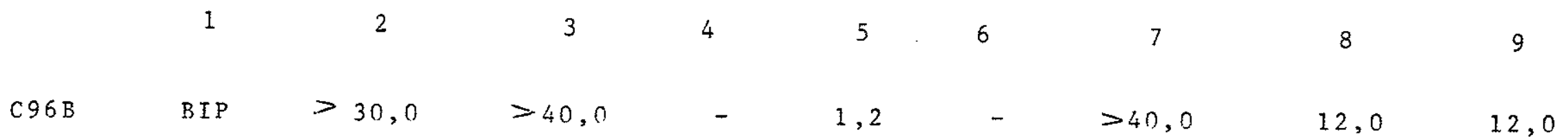
C 47 MON $>50,0$
- $\quad 1,7$
$=50, n$
$-\quad>22,0$

C 69

$\operatorname{MON}>18,0$

1,4

TABELA 4 - ASTEROTHECA CAMBUHYENSIS (Frondes estëreis)

\begin{tabular}{|c|c|c|c|c|c|c|c|c|}
\hline \multirow[t]{2}{*}{ T408 } & BIP & $>30,0$ & $=52,0$ & 3,1 & 2,0 & $7 n^{\circ} 80^{\circ}=45, n$ & 15,0 & 17,0 \\
\hline & & & & & 2,1 & $70^{\circ} 80^{\circ}=45,0$ & 15,0 & 17,5 \\
\hline
\end{tabular}

$\mathrm{T} 391$

$>50,0$

$=50,0$

2,3

3,4

$80 \%$

10,

5,0

5,0

B

$\operatorname{rr} 397$

$$
\text { BIP } \quad>45,0 \quad>45,0
$$

1,5
1,2
1,2
$-\quad>34,0$
$-\quad>30,0$
$-\quad=28,0$

12,0

12,0

13,0 


$\begin{array}{rrrrrrrrr}C 96 & 0,0 & 0,0 & 1,0 & 6,4 & 3,0 & 2,1 & 0,4 & - \\ \text { B } & 0,0 & 0,0 & 1,0 & 7,0 & 3,4 & 2,1 & 0,4 & 2 \\ & 0,2 & 0,3 & 1,0 & 7,5 & 3,0 & 2,5 & - & -\end{array}$
C 47
$-10,0$
$4,5 \quad 2,2$
$0,6=$
$\begin{array}{ll}5 & 2 \\ - & -\end{array}$
$0,4 \quad 1,0$
$0,6^{\circ} \quad 1,2$

C 69

$-\quad 10,0$

$4,0 \quad 2,5$

0,5

$\begin{array}{rlllllll}T 408 & 0,3 & 0,3 & 1,0 & 6,0 & 3,2 & 1,9 & - \\ & 0,4 & 0,4 & 1,0 & 6,2 & 3,6 & 1,7 & - \\ & 0,0 & 0,0 & 1,0 & 7,0 & 3,7 & 1,9 & \ldots\end{array}$

\begin{tabular}{|c|c|c|c|c|c|c|c|c|}
\hline T $391 *$ & 0,0 & 0,0 & 0,0 & 5,0 & 3,5 & 1,4 & $n, 3$ & - \\
\hline \multicolumn{9}{|l|}{ B } \\
\hline \multirow[t]{6}{*}{ T 397} & 0,0 & 0,0 & 1,0 & 6,0 & 3,0 & 2,0 & 0,3 & - \\
\hline & 0,0 & 0,5 & 1,0 & $6, n$ & 3,2 & 1,9 & - & - \\
\hline & 0,0 & 0,5 & 1,0 & $5 . n$ & 3,2 & 1,6 & - & - \\
\hline & 1,0 & 1,0 & 1,4 & 6,2 & 3,4 & 1,8 & 0,3 & - \\
\hline & 1,0 & 1,0 & 1,4 & 6,5 & 2.9 & 2,2 & - & - \\
\hline & 0,5 & 0,5 & 1,0 & 4,0 & 2,9 & 1,4 & - & - \\
\hline
\end{tabular}


No exemplar

T370

T369

$\mathrm{T} 435$

T27a

T97

C85
N8 Folha

C

L

C/L

\begin{tabular}{|c|c|c|c|c|}
\hline & 2 & 1,64 & 0,34 & 4,82 \\
\hline & 3 & 1,60 & 0,30 & 5,33 \\
\hline & 4 & 1,50 & 0,23 & 6,52 \\
\hline & 5 & - & 0,27 & - \\
\hline & 6 & - & 0,30 & - \\
\hline & 8 & 1,00 & 0,25 & 4,00 \\
\hline & 9 & 1,43 & 0,30 & 4,70 \\
\hline $\mathrm{T} 370$ & 10 & 1,60 & 0,25 & 6,40 \\
\hline & 11 & 1,60 & 0,25 & 6,40 \\
\hline & 13 & 1,60 & 0,26 & 6,15 \\
\hline & 14 & 1,20 & 0,34 & 3,76 \\
\hline & 17 & - & 0,25 & - \\
\hline & 19 & - & 0,25 & - \\
\hline & 29 & - & 0,26 & - \\
\hline & 30 & - & 0,26 & - \\
\hline & 31 & 0,90 & 0,25 & 3,60 \\
\hline & 5 & 1,30 & 0,20 & 6,50 \\
\hline T369 & 6 & 1,30 & 0,22 & 5,90 \\
\hline & 7 & - & 0,22 & - \\
\hline & 8 & 1,32 & 0,20 & 6,60 \\
\hline
\end{tabular}

6

1,30

0,24

5,40

1

3

7

8

0,80

0,18

4,44

0,75

0,18

4,16

0,70

0,18

3,88

0,50

0,20

2,50

3

0,92

0,20

4,60

1,65

0,27

6,11

1,10

0,23

4,78

Tabela 5 - Annularia occidentalis - Valores das medidas do comprimento (C) e largura (L) das folhas tomadas em seis espēcimes dessa espécie. mäxima desses valores, na tabela 6 (pägina seguinte). 
Variação da Relação $c / L$
Variaços verificacias na espécie ixemplar

Variação do Comprimento

(C) $\mathrm{sm} \mathrm{cm}$

T370

$\$ 369$

$927 a$

Cos

$$
0.03-1,63
$$

$$
0,90-1,64
$$$$
1,30-1,32
$$$$
0,30-0,30
$$$$
1,10-1,63
$$

$0,23-0,27$

$$
0,23-0,34
$$$$
0,20-0,22
$$$$
0,18-0,20
$$

(L) en ch

$$
\begin{aligned}
& 3,60-6,52 \\
& 3,90-0,60 \\
& 2,50-4,44 \\
& 4,75-6,11 \\
& 2,50-0,60
\end{aligned}
$$

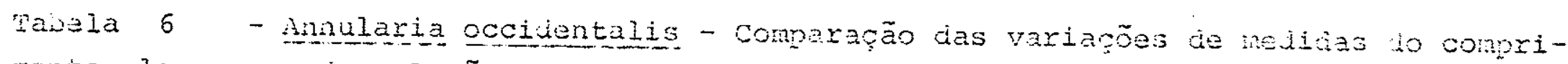
mento, largura e da relagão compinento/largura, oujervadas nas diferentes folias da uii nesmo esmeime, e a voriaç̃o global verificacia nesses valores no material estudado. Dados ostidos da tabeia 5 


\begin{tabular}{|c|c|c|c|c|}
\hline 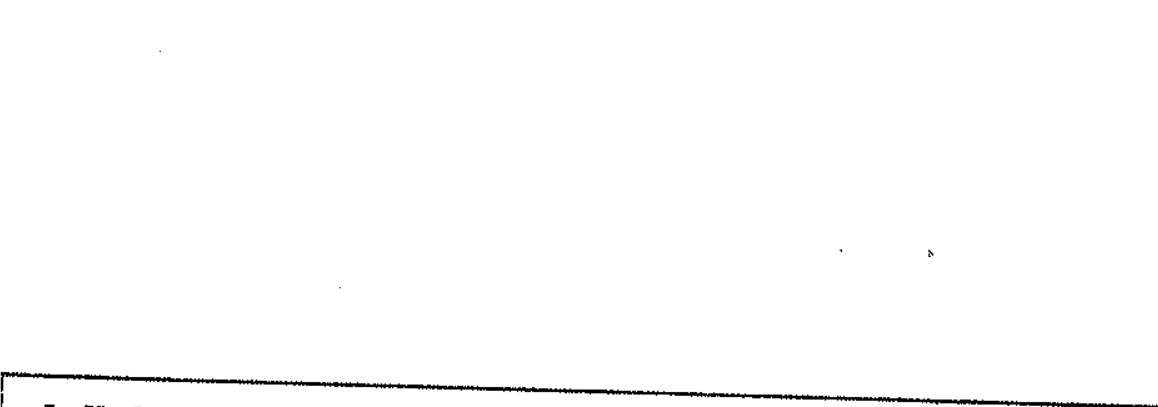 & 蛋 & 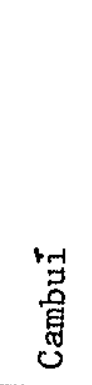 & 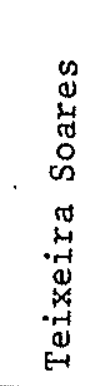 & 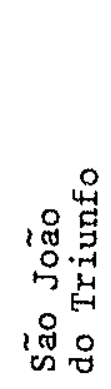 \\
\hline $\begin{aligned} \text { LY Y O P H Y T A } & \\
& \text { Lycopodiopsis pedroanus (Carruthers) Edwards } \\
& \begin{array}{l}\text { Lycopodiopsis sp. } \\
\text { Megásporos }\end{array}\end{aligned}$ & - & $\begin{array}{l}\oplus \\
\oplus \\
-\end{array}$ & - & $\bar{\oplus}$ \\
\hline 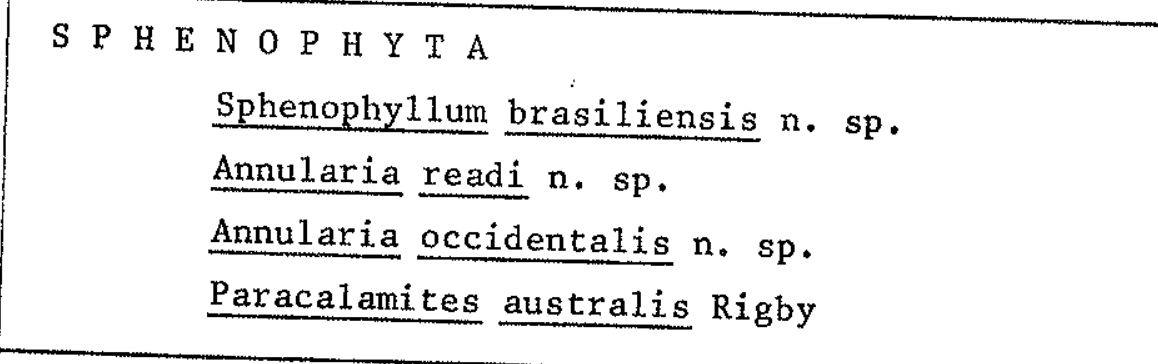 & $\begin{array}{l}- \\
- \\
+\end{array}$ & $\begin{array}{l}\oplus \\
\oplus \\
\oplus \\
\oplus\end{array}$ & $\begin{array}{l}- \\
-\end{array}$ & $\begin{array}{l}\oplus \\
\oplus \\
\oplus \\
\oplus\end{array}$ \\
\hline 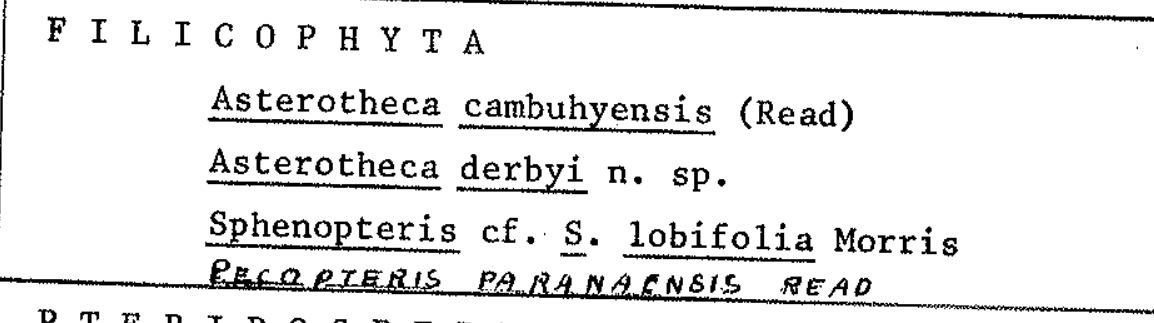 & $\begin{array}{l}- \\
- \\
-\end{array}$ & $\begin{array}{l}+ \\
\oplus \\
\oplus \\
+\end{array}$ & - & $\begin{array}{l}\oplus \\
\oplus \\
- \\
-\end{array}$ \\
\hline $\begin{array}{l}\text { P T E R I D O S P E R M A P H Y T A } \\
\text { Glossopteris communis Feistmante1 } \\
\text { Glossopteris orbicularis Feistmantel } \\
\text { Gangamopteris obovata (Carruthers) White }\end{array}$ & $\begin{array}{c}\oplus \\
- \\
-\end{array}$ & $\begin{array}{l}\oplus \\
- \\
+\end{array}$ & $\begin{array}{c}\oplus \\
+ \\
-\end{array}$ & $\begin{array}{l}\oplus \\
- \\
-\end{array}$ \\
\hline 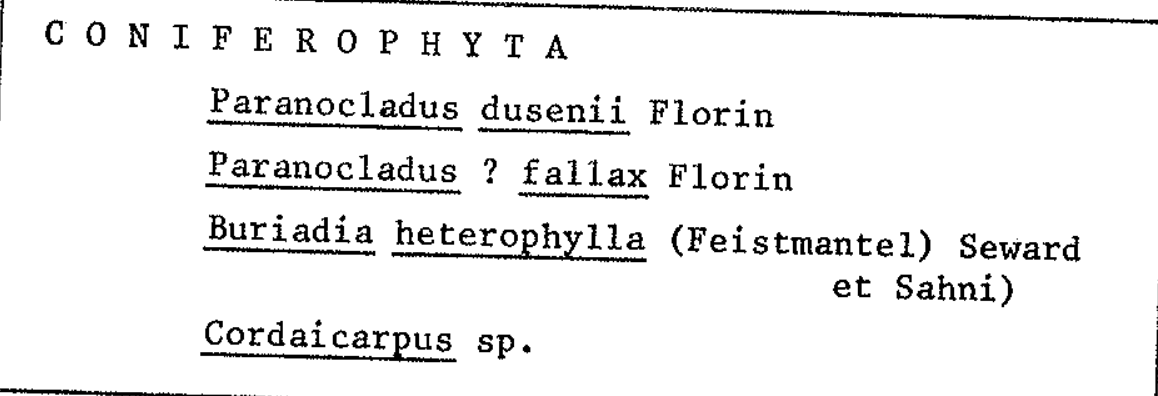 & + & $\begin{array}{l}\oplus \\
+ \\
\oplus\end{array}$ & $\begin{array}{l}+ \\
- \\
-\end{array}$ & $\begin{array}{l}- \\
- \\
- \\
-\end{array}$ \\
\hline
\end{tabular}

Tab. 7 - Ocorrência das formas de fósseis vegetais nas cinco principais localidades do Paraná.

$\oplus$ Forma encontrada nessa localidade durante as coletas para o presente trabalho.

+ Forma constatada, somente por outros autores, na localidade. 


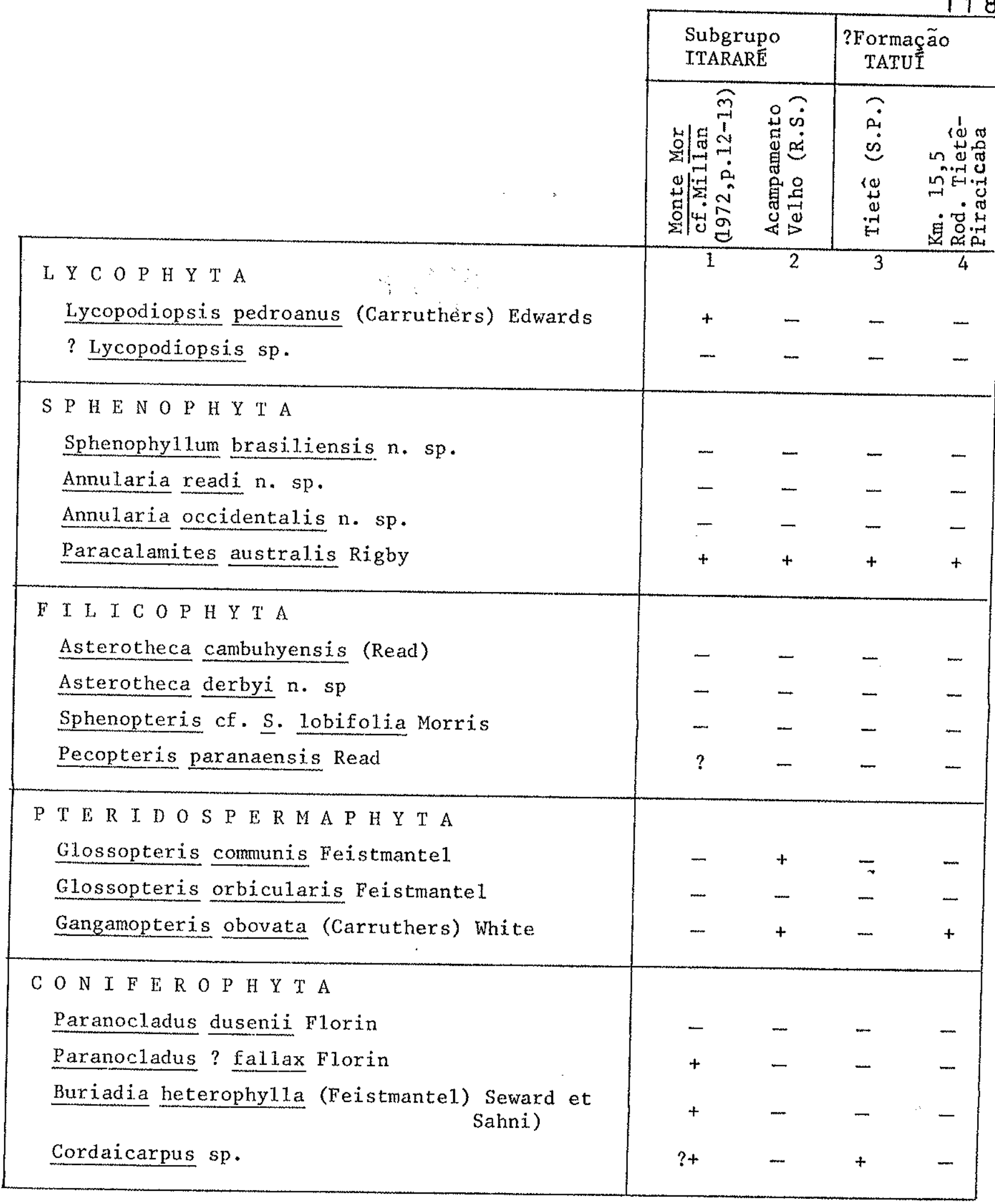

Tab. 8 - Distribuição das formas de fósseis vegetais que ocorrem na F. Rio Bonito (Paranä) em localidades fitofossiliferas do Subgrupo Itarare e da Bacia do Tietê. (cf. Millan, 1972; Rigby, 1970; Rigby, 1972).

Convençöes: - forma desconhecida nessa localidade.

+ Forma citada ou descrita nessa localidade.

? a forma corresponde duvidosamente a que ocorre nessa localidade. 


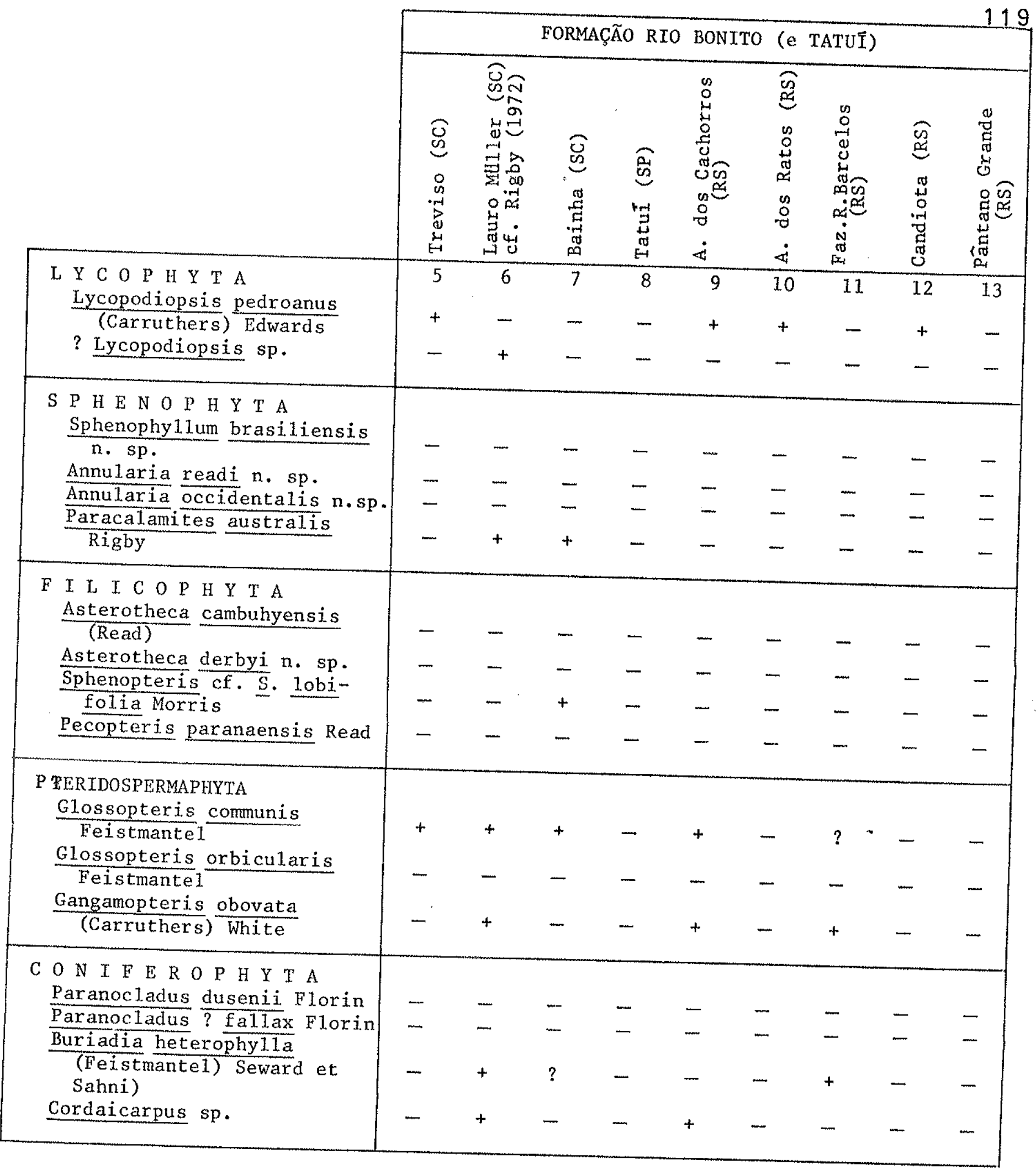

Tab. 9 - Distribuição das formas de fósseis vegetais que ocorrem na F. Rio Bonito (Paranā) em localidades fitofossiliferas da Formação Rio Bonito em outros Estados (cf. Rigby, 1970; Ri.gby, 1972). 


\begin{tabular}{|c|c|c|c|c|c|c|c|c|c|c|c|}
\hline & \multicolumn{5}{|c|}{ FORMAÇÃO } & \multicolumn{2}{|c|}{ ESTRADA } & \multicolumn{3}{|l|}{ NOVA } & \multirow[b]{2}{*}{ 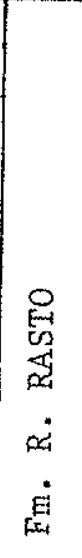 } \\
\hline & 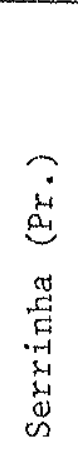 & 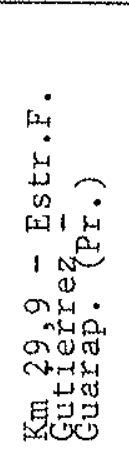 & 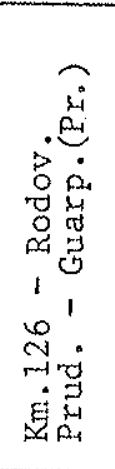 & 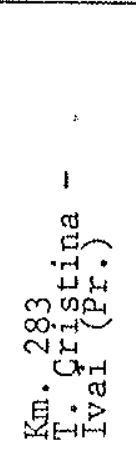 & 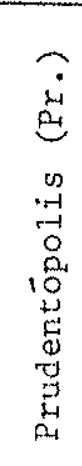 & 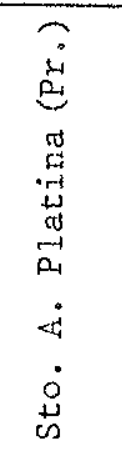 & 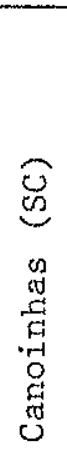 & 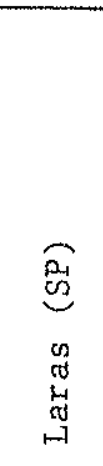 & 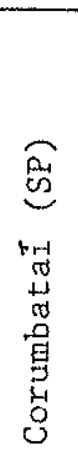 & 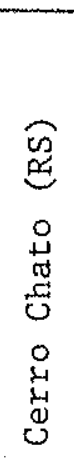 & \\
\hline $\begin{array}{l}\text { L Y C O P H Y T A } \\
\text { Lycopodiopsis pedroanus } \\
\text { (Carruthers) Edwards } \\
\text { ?Lycopodiopsis } \\
\text { sp. }\end{array}$ & $\begin{array}{l}14 \\
- \\
-\end{array}$ & 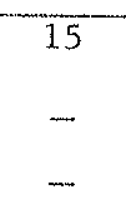 & $\begin{array}{l}16 \\
- \\
-\end{array}$ & - & - & - & - & - & $\begin{array}{l}22 \\
- \\
-\end{array}$ & -- & - \\
\hline $\begin{array}{l}\text { S P H I N O P H Y T A } \\
\text { Sphenophyllum brasiliensis } \\
\mathrm{n} \text { - } \mathrm{sp} . \\
\frac{\text { Annularia readi n. sp. }}{\text { Annularia }} \text { occidentalis n. sp } \\
\frac{\text { Paracalamites australis }}{\text { Rigby }}\end{array}$ & $\begin{array}{l}- \\
- \\
-\end{array}$ & $\begin{array}{l}- \\
- \\
- \\
-\end{array}$ & $\begin{array}{l}- \\
- \\
+\end{array}$ & $\begin{array}{l}- \\
- \\
-\end{array}$ & $\begin{array}{l}- \\
- \\
-\end{array}$ & $\begin{array}{l}- \\
- \\
+\end{array}$ & $\begin{array}{l}- \\
- \\
-\end{array}$ & $\begin{array}{l}- \\
- \\
+\end{array}$ & $\begin{array}{l}- \\
- \\
-\end{array}$ & $\begin{array}{l}- \\
- \\
-\end{array}$ & $\begin{array}{l}- \\
- \\
- \\
+\end{array}$ \\
\hline $\begin{array}{l}\text { F I L X C O P I Y T A } \\
\text { Asterotheca cambuhyensis } \\
\text { (Read) } \\
\frac{\text { Asterotheca derbyi n. sp. }}{\text { Sphenopteris cf. S. Lobi-- }} \\
\frac{\text { Polia Morris }}{\text { Read }}\end{array}$ & $\begin{array}{l}- \\
- \\
- \\
+\end{array}$ & $\begin{array}{l}- \\
- \\
- \\
-\end{array}$ & $\begin{array}{l}- \\
- \\
- \\
-\end{array}$ & $\begin{array}{l}- \\
- \\
- \\
-\end{array}$ & $\begin{array}{l}- \\
- \\
-\end{array}$ & $\begin{array}{l}- \\
- \\
- \\
-\end{array}$ & $\begin{array}{l}- \\
- \\
- \\
-\end{array}$ & $\begin{array}{l}- \\
- \\
- \\
?\end{array}$ & $\begin{array}{l}- \\
- \\
- \\
-\end{array}$ & - & $\begin{array}{l}- \\
- \\
- \\
-\end{array}$ \\
\hline $\begin{array}{l}\text { PTERIDOSPERMAPHYTA } \\
\frac{\text { Glossopteris communis }}{\text { Feistmantel }} \\
\frac{\text { Glossopteris orbicularis }}{\text { Feistmante1 }} \\
\frac{\text { Gangamopteris obovata }}{\text { (Carruthers) White }}\end{array}$ & - & $\begin{array}{l}- \\
- \\
-\end{array}$ & - & - & $\begin{array}{l}- \\
- \\
-\end{array}$ & - & $\begin{array}{l}- \\
- \\
-\end{array}$ & - & - & - & - \\
\hline 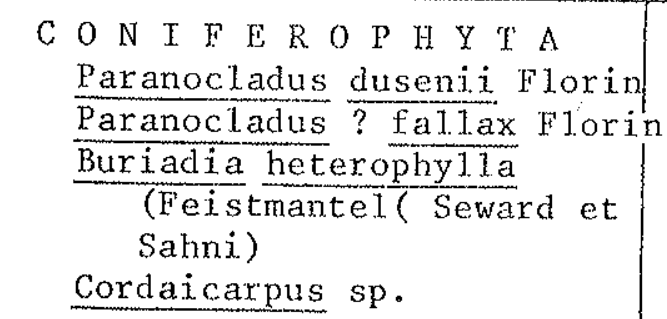 & - & $\begin{array}{l}- \\
- \\
- \\
-\end{array}$ & $\begin{array}{l}- \\
- \\
-\end{array}$ & - & - & $\begin{array}{l}- \\
- \\
- \\
-\end{array}$ & $\begin{array}{l}- \\
- \\
- \\
-\end{array}$ & - & - & - & - \\
\hline
\end{tabular}

Tab. 10 - Distribuição das formas de fósseis vegetais que ocorrem na F. Rio Bonito (Paraná) em localidades fitofossilife-m ras da Forinação Estrada Nova (Grupo Passa Dois) (cf.Yoshida, 1970; Rigby, 1970) 


\begin{tabular}{|c|c|c|c|c|c|c|c|c|}
\hline & \multirow{2}{*}{\multicolumn{2}{|c|}{$\begin{array}{c}\text { ARGENT. } \\
\text { P inf. }\end{array}$}} & \multirow{2}{*}{\multicolumn{4}{|c|}{$\begin{array}{lllll}I & N & D & I & A \\
C & \text { SUD } & P_{1} & P_{S}\end{array} \mid$}} & & \\
\hline & & & & & & & \multicolumn{2}{|c|}{ AUSTRÁLIA } \\
\hline & 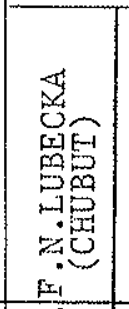 & 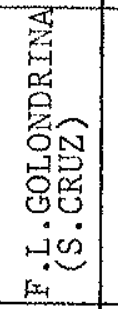 & 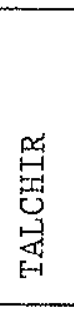 & 占 & 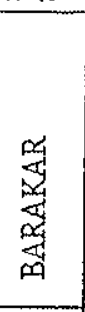 & 营 & 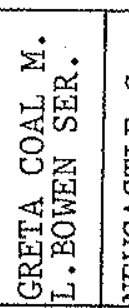 & 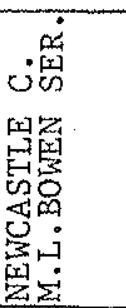 \\
\hline $\begin{array}{l}\text { L. Y C O P H X T A } \\
\frac{\text { Lycopodiopsis pedroanus }}{\text { (Carruthers) Edwards }}\end{array}$ & 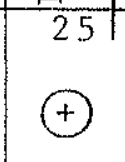 & $\begin{array}{l}26 \\
+\end{array}$ & $\begin{array}{r}27 \\
-\end{array}$ & $\begin{array}{r}28 \\
-\end{array}$ & $\begin{array}{r}29 \\
-\end{array}$ & $\begin{array}{r}301 \\
-\end{array}$ & 31 & $\frac{12}{32}$ \\
\hline ? Lycopodiopsis sp & (c) & - & - & - & $\therefore$ & - & - & - \\
\hline $\begin{array}{l}\text { S P HEN O P H Y T A } \\
\text { Sphenophyllum brasiliensis } \\
\text { n. sp. } \\
\text { Annularia readi n. sp. } \\
\text { Annularia occidentalis n.sp. } \\
\text { Paracalamites australis Rigby }\end{array}$ & $\begin{array}{l} \pm \\
- \\
+\end{array}$ & $\stackrel{\bar{\oplus}}{+}$ & $\frac{-}{-}$ & $\begin{array}{l}- \\
- \\
-\end{array}$ & $\frac{-}{-}$ & $\begin{array}{l}- \\
- \\
- \\
+\end{array}$ & $\begin{array}{l}- \\
- \\
+\end{array}$ & $\begin{array}{l}- \\
- \\
-\end{array}$ \\
\hline $\begin{array}{l}\text { F I L I C O P H Y T A } \\
\text { Asterotheca cambuhyensis } \\
\text { (Read) } \\
\text { Asterotheca derbyi n. sp. } \\
\text { Sphenopteris cf. S. Iobi- } \\
\text { Pecopteris paranaensis Read }\end{array}$ & $\begin{array}{l}\oplus \\
\oplus \\
\oplus\end{array}$ & $\begin{array}{l}\oplus \\
- \\
(c f)\end{array}$ & $\begin{array}{l}- \\
- \\
- \\
-\end{array}$ & - & $\begin{array}{l}- \\
- \\
-\end{array}$ & - & $\begin{array}{l}- \\
- \\
\text { (cf) }\end{array}$ & - \\
\hline $\begin{array}{l}\text { PTERTDOSPERMAPHYTA } \\
\frac{\text { Glossopteris communis Feist- }}{\text { mantel }} \\
\frac{\text { Glossopteris orbicularis }}{\text { Feistmante } 1} \\
\frac{\text { Gangamopteris obovata }}{\text { (Carruthers) White }}\end{array}$ & + & + & - & - & - & - & + & $\begin{array}{c}+ \\
- \\
+\end{array}$ \\
\hline 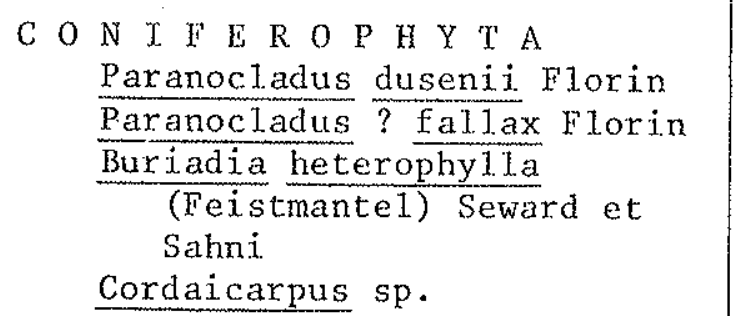 & $\Theta$ & cE & $\begin{array}{l}- \\
- \\
-\end{array}$ & $\begin{array}{l}- \\
- \\
+ \\
-\end{array}$ & $\begin{array}{l}- \\
- \\
+ \\
-\end{array}$ & - & - & $\begin{array}{l}- \\
- \\
-\end{array}$ \\
\hline
\end{tabular}

Tab. 11 - Distribuição das formas de fósseis vegetais que ocorrem na Formaçăo Rio Bonito (Paranā), na Argentina, Îndia e Austrāilia.

Convençöes: - não ocorre.

+ ocorrencia assinalada na literatura.

+ formas comparadas pejo autor.

(C) formas talvez correspondentes.

$\oplus$ formas diferentes, porem estreitamente relacionadas. 


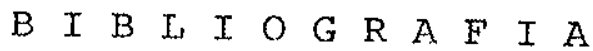

ALMEIDA, F. F. M. de - 1945 - Episódio da ültima ëpoca interglacial permo-carbonifera no parană. Div. Geol. Miner., D.N.P.M., Notas Prelim. e Estudos, 27: 1-18 (Rio de Janeixo).

AMARAL, J. C. et ODDONE, D. S. - 1940 - Reconhecimento magnëtico em Barra Bonita (in Carvão Mineral de Barra Bonita e Carvãozinho) DNPM, Div. Fom. PM., Bol. no 42: 1.9-27, 5 figs., 2 estps. - (Rio de Janeiro).

ANDREWS, H. N. - 1970 - Organes sporangiës de Marattiaceae fossiles - (in Boureau 1970 - Traitē de PalëonbotaniqueFilicophyta - V. 4, fasc. 1 - Paris) : 203-225.

ARBER, E. A. N. - 1905 - Catalogue of the fossils plants of the Glossoptexis Flora in the Department of Geology, Bri tish Museum (Natural History). II + 255 pp. 51 textfig., $8 \mathrm{pl}$. Darling \& Son Lta./ London)

ARCHANGELSKY, S. - 1958 - Estudio geológico y paleontológico del Bajo de La Leona (Santa Cruz). Acta Geol. Lilloana, 2: $5-134$ (Tucuman).

- 1960 - Lycopsida y Sphenopsida del Paleozoico Superior de Chubut y Santa Cruz, Patagonia. Acta Geol. Lilloana, 3: 21-36 (Tucuman).

- 1970 - Fundamentos de Paleobotanica. Mus. La Plata, Ser. Tec. Didact., 11, 347 pp. (La Plata).

ARCHANGELSKY, S., ARRONDO, O. G. - 1966 - Elementos floxisticos del péxmico argentino. II - "Rhacopteris chubutiana n. sp. "de la Formación Nueva Lubecka, Provincia de Chubut. Rev. Mus. La Plata (n.s.), Paleont. 5(28) : 1-16 (La plata).

- 1969 - The Permian taphofloras of Argentina - With some considerations about the presence of "Noxthern" Elements and their possible significance. IUGs symp., Buenos Aires 1-15 October 1967, Gondwana Strat.; 7190 , Unesco (Paris).

- 1971 - Las tafofloras del sistema Paganzo en la Repu blica Argentina (in Simpósio Bras. Paleontol. Asn.Ac. Br.Ci. - v. 43 - suplemento - Rio de Janeiro):67-88. 
ARCHANGELSKY, S., IAA SOTA, E. de - 1960 - Contribución a T conocicimiento de las Filices Pérmicas de Patagonia Extraandina. Acta Geol. Lilloana, 3: 85-126, 7 pl. 133 fig. (Tucuman).

ARNOLD, C. A. - 1947 - An introduction to Paleobotany.

$433 \mathrm{pp}$. McGraw-Hill Book Company, Inc. (New York).

ARRONDO, O. G. - 1972 - Sintesis del Conocimiento de las tafofloras del Paleozöico superior de Argentina. Apres. no Simp. Int. Sist. Carbon. Permiano na Am. do sul (Ac.Br. Ci.) 19-30/11/72 (São paulo)-

ASAMA, K. - 1966a - Permian plants from phetchabun, thailand and problems of floral migration from Gondwanaland. Contri butions to the Geology and Pateontology of southeast Asia, XXV. Bull. Nat. Sci. Mus. Tokyo, 9 (2) : 171-211 (T'okyo).

- $\quad$ - $1966 \mathrm{~b}$ - Two types of evolution in sphenophyzlum. Bull. Nat. Sci. Mus. Tokyo, 9 (4) : 577-608 (Tokyo).

- 1970 - Evolution and Crassification of Sphenophyzlazes in Cathaysia Land. Bull. Nat. Sci. Mus. Tokyo, 13 (2): 291-317 (Tokyo).

BAKSI, S. K. - 1969 - On the Paleobotanical Biostratigraphy of the Gondwana rocks of India (in La estratigrafia del Gondwana - Vol. ref. Coloquio UICG - 2) : 123-124 (Mar del Plata).

BARBOSA, O. - 1952 - Comparison between the Gondwana of Brazil, Bo livia and Argentina. Congrès Gëol. Inter., 19e, symp. Gondwaria: 313-324 (Alger).

BARBOSA, O. - 1958 - On the age of the Lower Gondwana Floras in Brazil and abroad. Xx Cong. Geol. Int., 20a. ses.: 205-236 (Mèxico).

BIGARELLA, J. J., SALAMUNI, R. - 1967 - A review of South American Gondwana Geology. IUGS symp., Gondwana strat.: 7-138 (Max del plata).

- 1967 - Some paleographie and paleotectonic features of the Parana Basin. In T. T. Bigarella, R. D. Becker et J. D. Pinto (Editores): Froblems in Brazilian Gondwana: 235-301 (Curitibal 
BOUREAU, E - 1964 - Traitë de Palëobotanique Tome III Sphenophyta e Noeggerathiophyta. 544 pp., 436 figs. - Masson et Cie., Editeurs, 120, Boulevard Saint Germains (Paris). - 1970 - Traité de Fatéabotanique - Filicophyta 4(1): $1-519,378$ figs.

CARRUTHERS, W. - 1869 - On the plants remains from the Brazilian coal beds with remarks on the genus flemingites. Geol. Mag., 6 (58): 151-155. (London).

CHALONER, W. G., BOUREAU, E. - 1967 - Lycophyta, in Traite de paZéobotanique, II.: 435-802, Masson et Cie., Editeurs (Paris).

DAEMON, R. et QUADROS, L - 1969 - Bioestratigrafia do Neopaleozöico do paraná. Res. Com. XXIV Cong. Soc. Bras. Geol., Nücleo Centro Oeste, Bol. Esp. (1):309-310.

DECOURT, R. R. - 1940 - Estudo quimico dos carvões das Bacias de Barra Bonita e Carvãozinho (in Carvão Minexal de Barra Bonita e Carvãozinhol D.N.P.M. - Div. Form. P. M. Bol. n. $42,4 \mathrm{fig} .$, tabelas (Rio de Janeiro).

DOLIANITI, E. - 1945 - Um novo elemento na flora fóssil do BrasizSphenozamites Brongniart - Notas Prelim. Estudos Bras. $34,1-6$ (Rio de Janeiro)

- 1948 - A Paleobotânica no Brasiz. Div. Geol. Miner., D.N.P.M., Bol. ].23:1-87 (Rio de Janeiro).

- 1952 - La Flore fossile du Gondwana au Brêsiz d'aprés sa position stratigraphique. Congrès Geol. Intern., 19e., Symp. Gondwana: 285-301 (Algex).

1954 - Glossopteris orbicularis Feistmantel em Teixeira Soares, Paranä. Paleontologia do Paranä (ParanáCom. Comemox. do Centenáxio, Curitiba) - 149-150, 1 fig. 1972 - Relacäo entre as floras paleozöicas do Brasit. Apresentado no Simpósio Int. Sist. Carb. Perm. Am. Sul. 19.30/11/72. Acad. Bras. Ci. Inst. Geociências - USP (são paulo).

DUTRA, E, B. - 1940 - bacia do Carvãozinho (in Carväo Mineral de Barra Bonita e Carvãozinho) D.N.P.M. - Div. Form. P.M., Bol. no 42 : 39-42 (Rio de Janeiro). 
EDWARDS, W. N. - 1952 - Lycopodiopsis, a Southern hemisphere Lepidophyte. palaeobotanist, 1: 159-164 (Lucknow).

FERUGLIO, E. - 1933 - Fossiti liassici della vale del rio Genua (Patagonia) - Giornale di Geologia, Annali R. Museo di Bologna, IX: $1-54$ (Imola).

- 1942 - La flora liásica del valle del valze del rio Genua (Patagonia) - Ginkgoales et Gymnospermae incertae sedis, en Notas Museo la Plata, VIJ, 6(40): 93-110 (La Plata).

- 1949 - Descripición geológica de Patagonia, Vol. I (Bue nos Aires).

- 1951 - Su alcune piante del Gondwana inferiore delza Pa tagonia, en Publicazioni Inst. Geol. Univ. Torino, I: $1-34$ (Torino).

FLORIN, R. - 1940a - Die Koniferen des oberkarbons und des unteren Perms. Palaeontographica, Abt. R, 85 (5): 243-364 (stuttgart).

- FRENGUELLI, J. - 1953 - Las pecopterideas del pérmico del Chubut. Notas del Museo - Fac. Ciencias Nat. y Mus. Univ. Nac. de Eva Perōn 16 (Pal. 99): 287-296, 6 pl. (La Plata).

FULFARO, V. J.; LANDJM, P. M. B., et BOSIO, N. - 1971 - Roteiro de Excursão n! 3, Bacia do Paranä - Soc. Bras. Geol., Nücleo de S. paul.c - Bol. Esp (2): 29-48.

KAR, R. K. - 1967 - A fossil resembling Pediastrum from the Barren Measures Sequence of Tharia Coalfield, Bihar, India The Pal. 16(3): 216-218; 1 pl., 5 fig. 1 text fig. (Lucknow).

KRAUSEL, R. - 1961 - Lycopodiopsis derbyi Renault und einige andere Lycopodiales aus den Gondwana - Schichten. Palaeon tographica, Abt. B. 109:62-92, plates 32-41 (Stuttgart).

- 1961 - Palaeobotanical Evidence of CZimate (in Descrip tive Paleoclimatology, Ed. by A.E.M.NAIRN - Intercience Publishers Inc., New York) : 227-254,6 tabelas.

KURTZ, F. - 1921 - Atzas de plantas fósiles de ta Repüblica Argentina. Act. Acad. Cien. Córdoba, 7: 129-153 (Córdoba). 
- LANGE, F. W. - 1954 - Paleontologia do Parana. Volume comemor. cent. do paranā, : 1-105, alēm de outras contribuições. p. 107-210, $31 \mathrm{pl}$. (Curitiba).

LEINZ, V. - 1937 - Estudos sobre a Glaciagão Permo-Carbonifera do sul do Brasil. DNPM, Div. Form. Prod. Mineral D.2I, $47 \mathrm{p}$. (Rio de Janeiro).

- 1940 - Gênese do Carvão do Norte do Paraná (in Carvão Mineral de Barra Bonita e Carvãozinho) DNPM Div. Form. Bol. 42: 43-65. Est. IV-VI; ils. (Rio de Janeiro).

LUNDQVIST, A. G. - 1919 - Fossize Pflanzen der Giossopteris Flora aus Brasizien. Kungl. Sven. Vet. Akad. Handl., 60 (3): 1-36. (stockholm).

MAACK, R. - 1953 - Mapa Geológico do Fst. do Paranä - 1:750.000Inst. Biol. Pesq. Tecnol. (Curitiba).

MAHESWARI, H. K. - 1967 - Studies in the Glossopteris flora of India 34. On a record of Phyltotheca austratis. Brong. from tharia Coalfield, Bihar. The Pal. - 16 (2): 167169, 1 pl., 4 figs. (Lucknow).

- 1967 - Studies in the Glossopteris flora of India.38 Remarks on rhizygia speciosa Royle with reference to the genus Sphenophylzum Koenig. The Pal. 16(3): 283287 (Lucknow).

MAMAY - 1950 - Some American Fern Fructification. Ann Miss. Bot. Gard. $37: 409-476$.

MAU, H. - 1958 - Contribuigão para a geologia da região de Ibaiti, Parană: Soc. Bras. Geol., Bol. v. 7, n. 1 p. 1328 , ils. (S. Faulo).

MEDETROS, R. A. - 1971 - Roteiro da Excursão no 2, Bacia do Para ná - Soc. Bras. Geol. Nücleo S. Paulo - Bol. Esp. nọ 2 , pp. $15-28$ (S. Paulo).

MEMPEL, G. - 1957 - Das Obercarbon in Nord-ost Parana (Brasilien) in Beitrăge zur Geologie von Brasilien (Beih Geol. Jb., Heft $25, p .33-79$ ) (Hannover).

MENDES, J. C. - 1952 - The Gondwana Formations of Southern Brazil: Some of their stratigraphical problems, with emphasis on the fossit flora - B.S.Mem Vol - BirbaI s. Inst. Faleob. - 1:336-345; 5 text - fig. (Lucknow). 
MENDES, J. C. - 1954 - Contribuigão à estratigrafia da sërie Pas sa Dois no Estado do Paranä. Fac. Fil. Cienc. Letr., USP, Bol. 175, Geol. 10: 1-119, 3 pl. (São Paulo).

- 1965 - Introducão à Paleontologia. Comp. Ea. Nac., Bibl. Univ., Ciências puras, 3, $382 \mathrm{pp}$. (São paulo).

- 1967 - The Passa Dois Group (The Brazilian portion of the Parana Basin) (in Problems in Gondwana Geology. Edit. by J. J. Bigarella et al.) : 119-166; 7 text fig., p1. 41-52 (Curitiba).

MENDES, J. C. ; FŬLFARO, V. J. - 1966 - As Camadas Gondwanicas no Norte do Paranā, Bol. Soc. Bras. Geol. v. 15 (4):29m 42 (s. Paulo).

MENENDEZ, C. A. - 1966 - Paleontografia Bonaerense. II. Plantas Fosiles. Com. Inv. Cient., 35 pp. 9 pl. (B. Aires). MEYEN, S. V. - 1969 - New data on relationship between Angara and Gondwanc Late Paleozoic Floras. IUGS Symp., Bue nos Aires 1-15 October 1967, Gondwana Strat.: 141-158.

MILLAN, J. H. - 1965 - Consideragões sobre as sementes do Carbonifero do Brasiz. Div. Geol. Miner., D.N.P.M., Notas Prelim. Estudos, 123: 1-18 (Rio de Janeiro).

- 1967 - O gênero Samaropsis na Flora do Gondwana do Brasil e de outros paises. Bol. Mus. Nac., n. s., Geol. 32: 1-12 (Rio de Janeiro).

- 1969 - The Gymnospermic and Platyspermic seeds of the Glossopteris Flora from Brazil and correlated foreign regions, IUGS Symp., Buenos Aires 1-15 oct. 1967 , Gondwana strat.; 107-122.

- 1972 - Macroflorula Carbonifera de Monte Mor, Est.de São Paulo - Tese Doutoram. Inst. Geociências - USP (S. Paulo).

MUSSA, D. - 1958 - Conifera fóssit do Carbonifero Superior de Sta. Catarina - D.N.P.M. Div. Geol. Mineral - 182 ; 23 p., 4 pl. (Rio de Janeiro).

NORTHFLEET, A. A.; MEDETROS, R. A., et MUHLMANN - 1969 - ReavaZiacão dos dados geolögicos da Bacia do paraná -. Bol. Tecn. Petrobrás 1.2(3): 291-346 (Rio de Janeiro). 
OLIVEIRA, E. P. de - 1927 - Geologia e recursos minerais do Estado do Paraná. Sexv. Geol. Miner., monog. 6: 1-172 (Rio de Janeiro).

OLIVETRA, G. M. de Araüjo - 1953 - Carvão Mineral do Paranä DNPM - Div. Form. Bol. 94 (Rio de Janeiro).

OLIVEIRA, M.E.C.B. - 1969 - Flora da Formagão Rio Bonito:Glossopteris, Noeggeratiopsis, Sphenopteris, Gangamopteris e Rhabdotaenia na subida do Bainha - Tese mestrado usp (são Paulo).

PAIVA, G. - 1940 - Consideracões sobre os resultados das prospeccões para o Carvão Mineral no Norte do Paranä (in Car vão Mineral de Barra Bonita e Carvãozinho) DNPM -Div. Form. P. M. - Bol. 42, p. 67-1.27 (R. de Janeiro).

PANT, D. D.; NAUTTYAL, D. D. - 1967 - On the structure of Buriadia heterophyzza (Eeistmantel) seward \& Sahni and its fructification. Phil. Trans. B, 252 (774): 27-48 (London).

PINTO, I. D.; CLOSS, D. - 1967 - Indice remissivo dos fósseis do Rio Grande do Sul - Theringia, Geol. 1: 3-76 (Porto Alegre).

POTONIE, R. - 1958 - The taxonomy of fossiz plants (Include spore dispexsae) in the International Code of Botanical Nomenclature; 1956 - The Paleob. Bir. Sah. Inst. Paleob. 7 (1) : 32-42 (Lucknow - India)

PUTZER, H. - 1952 - Camadas de carvão mineral e seu comportamento no sul de Santa Catarina. Div. Fom., D.N.P.M., Bol. 91: 1-182 (Rio de Janeiro).

READ, C. B. - 1941 - Plantas fösseis do Neopaleozóico do Parana e Santa Catarina - Div. Geol. Miner., D.N.P.M., monog. 12: 1-102 (Rio de Janeiro).

RIGBY, J. F. - 1966 - The Lower Gondwana Froras of the Perth ard Collie basins, Western Australia. Palaeontographica Abt. B, $118(4-6): 113-152$ (Stuttgart).

- 1968 - Hew fossil plant locality near Laras, state of são Paulo. Soc. Bras. Geol., An. XXII Cong.: 201-208 (Belo Horizonte). 
RIGBY, J. F. - 1969 a - Permian Sphenopsids from Antaretica. Geol. Surv. Prof. Paper 613-F: 1-12 (Washington).

1969 - The Lower Gondwana Scene. Bol. Paranaense Geo ciênc., 27: 3-14 (Cuxitiba).

- $\quad 1970$ - whe distribution of Lower Gondwana plants in the Paxana basin of Brazil. Proc. Gondwana Symp.: 575584 (Pretoria).

ROCHA- CAMPOS, A. C. - 1967 - The Tubarão Group in the Brazizian portion of the Parana Basin. In Bigarella, J. J. ed. problems in Bxazilian Gondwana Geology: 27-102, pl.332 (Cuxitiba).

- 1972 - Late Paleozoic Geology of Northern Paranä Basin - In Excuxsion Guide Book - Intern. Symp. Carbon/ perm. Systems in South America - Ac. Bxas. Ciências : $1-68$ (são paulo).

SEWARD, A. C. - 1941 - Plant life through the ages. A geological and botanical retrospect. Cambridge Univ. Press, 607 pp. (Cambridge).

SEWARD, A. C.; SAHNI, B. - 1920 -Indian Gondwana plants. "A revision. pal. Ind., mem.1, n.s., 3: 1m54 (Calcutta).

SOMMER, F. W.-1954- Contribuiçáa. à paleofitografia do Parana Paleont. do Paranä - Com. Comem. do Centenärio - Para ná : 175-194, pl.15m20 (Cuxitiba).

SOMMER, F. W。: TRINDADE, Nicëa M。 - 1966 - Lycopodiales do Gondwa na brasiteiro. Div. Geol. Miner., D.N.P.M., Bol. 230: I-3I (Rio de Janeiro).

SRIVASTAVA, P. N. - 1956 - Studies in the Glossopteris Flora of India - Glossopteris, Gangamopteris and Paleovittaria from the Raniganj Coaldfield - The Paleob - Birb Sah. Inst. Paleob. - 5(1); 1-45, 43 text fig; 14 pl., 95 figs., 2 tab (Lucknow).

STENBERG, G. K. - $1923-1825-$ Yersuch einex geognotisch - botanische Darstellung der Flora der: Vorvelt 2-4 (Regens berg).

YoshrDA, R. - 1970 - Novo gênero de coniffera da Formąão Estrada Nova, norte do Estado de Santa Catarina Divo Geol. Miner., D.N.P.M., Bol. 249: 1-17, 4 est. (Rio de Jam neiro). 
WHITE, I.C. - 1908 - Relatörio sobre as Coal Meausures e rochas as sociadas do sul do Brasir - Final Report - Comissão Estudos Minas Carvão de Pedra do Brasil, Part. 1, pp.1 300 , ils, maps. (Rio de Janeiro).

ZALESSKY, M. D. - 1930 - Sur l'extension de la flore fossile paren te de la flore Gondwanienne dans la partie nord de l'Eurasie (em russo). Bull. Acad. Sci. URss, classe d. Sc. mathem. e natur., 9: 913-930 (Moscow).

ZENBER, F. C. - 1837 - Scolecopteris elegans Zenk. Ein neues fossiles Farngenvichs mit Erutification - Linnaca - 11: 509-512. 
LYCOPHYTA - Procedência: Cambui (Pr.)

Formação Rio Bonito - Grupo Tubarão

Fig. 1 - Lycopodiopsis pedroanus (Carruthers)

Edwards

Exemplax C28 - x1,0 (Vide fig. 4) ...... päg.26

Fig. 2 - Lycopodiopsis sp. -

Exemplar $C 25-x 1,3 \ldots \ldots \ldots \ldots \ldots$ päg.26

Fig. 3 - Lycopodiopsis pedroanus -

Exemplar C114 - x1,1............. päg.26

Fig. 4 - Lycopodiopsis pedroanus -

Exemplar C28-x2,5 (aprox.) ......... pāg.26

Fig. 5 - Licofita em estägio avançado de

decorticação (forma "Bergeria")

Exemplax C115 $-x 1,0 \ldots \ldots \ldots \ldots$ päg.26 


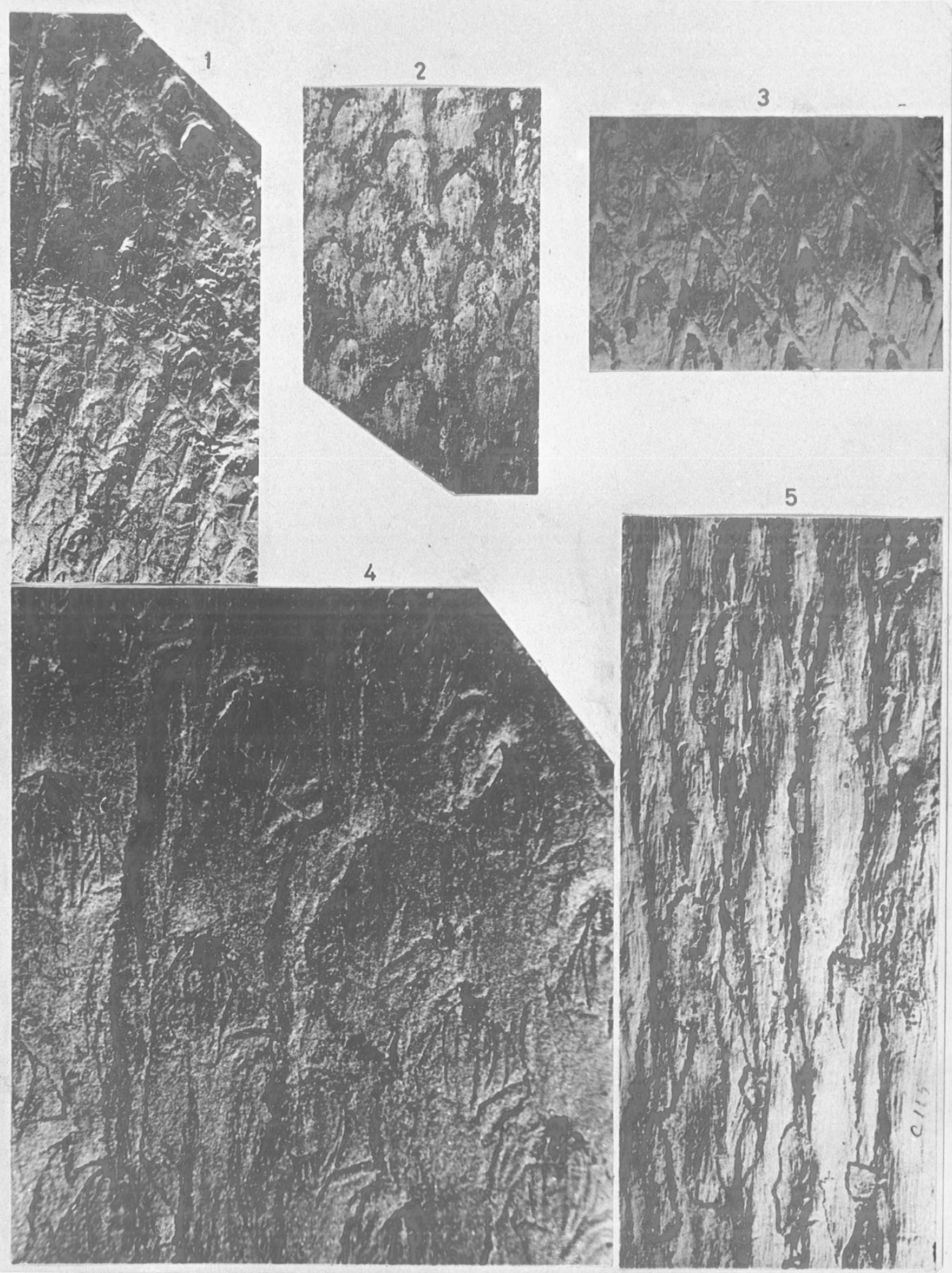


Fig. 6 - 9 - SPHENOPHYTA $(6$ - 8 de São João do Triunfo; 9 do Cambuí - $\operatorname{Pr}$.

Fig. 10 - 11 - CONIFEROPHYTA - de Cambuí (Pr.)

Fig. 6 - Annularia readi $n$. sp.

Exemplar T50a (Holótipo) - x 2,6 ....... pāg. 39

Fig. 7 - Annularia readi n. sp.

Exemplar T107-x 2,6 ................... 39

Fig. 8 - Annularia occidentalis n. sp.

Exemplar T370a (Holótipo) - x 2, $6 \ldots \ldots$ pāg.35

Fig. 9 - Paracalamites australis Rigby

Exemplar ClB - x 1,6 c/ ramo lateral .... pāg.4i

Fig. 10 - Paranocladus ? fallax Florin

Exemplar $\mathrm{C} 4-\mathrm{x} 3,6 \ldots \ldots \ldots \ldots \ldots \ldots$ pág. 81

Fig. 11 - Paranocladus ? fallax Florin

Exemplar C109 - x 2,7

Porção terminal de ramos ............. pāg.81 


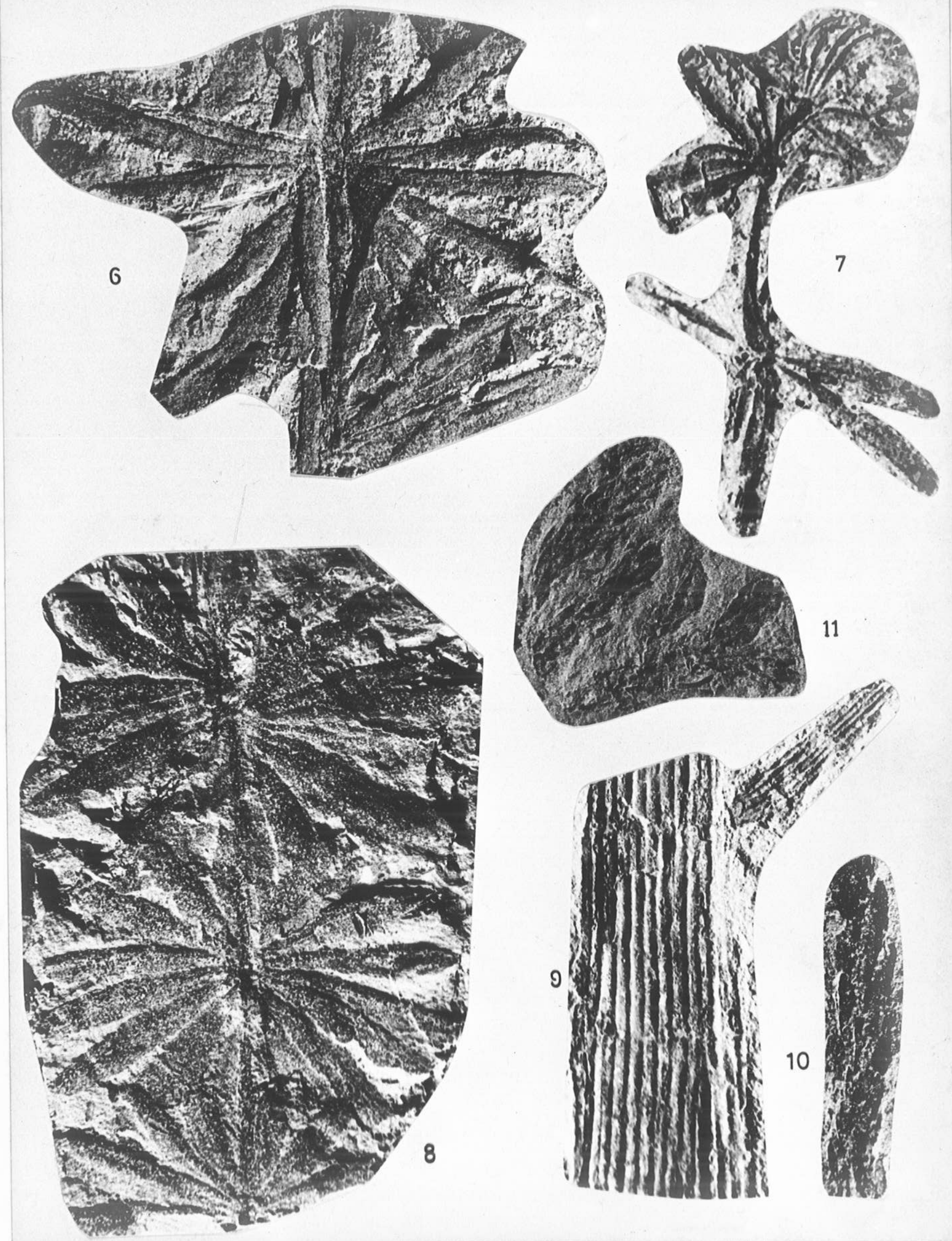


Fig. 12 - 15 - Asterotheca cambuhyensis (Read) Procedência: São João do Triunfo

Fig. 16 - 18 - Sphenophyllum brasiliensis n. sp. Procedência: Cambuí

Fig. 12 - Parte terminal de fronde estēril mostrando os sucessivos graus de diferenciação das pinas. Exemplar т391в - х 2,9 ......... pág. 55

Fig. 13 - Parte terminal de pinas estēreis adultas

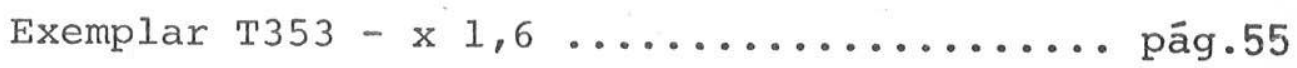

Fig. 14 - Parte basal de pinas estēreis adultas. Exemplar T397 - x 2,1 ...................... 55

Fig. 15 - Parte de fronde fértil. Exemplar $\mathrm{T} 237-\mathrm{x} 0,9 \ldots \ldots \ldots \ldots$ păg. 55

Fig. 16 - Verticilo - Exemplar C33b - x 4,6 ....... pág.30

Fig. 17 - Fragmento com parte de dois verticilos e um entrenó. Exemplar c86 (Holótipo)

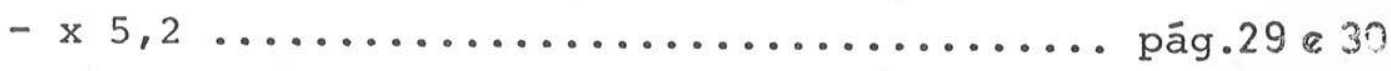

Fig. 18 - Verticilos - Exemplar C84 - x 5,2 ....... pág. 30 
Fig. 19 - 23 - Asterotheca derbyi n. sp.

Proced.: São João do Triunfo

Fig. 19 - Parte de fronde fértil, com os sinângios parcialmente removidos.

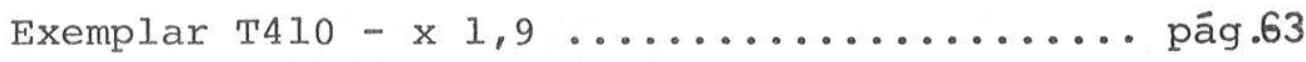

Fig. 20 - Parte de fronde fértil, mostrando a diferença entre as pínulas basais e apicais. Exemplar T415 - x 0,9 ......... päg.63

Fig. 21 - Parte de fronde estēril; observe-se a nervação das pínulas. Exemplar т391A - x 1,5 ...................... 63

Fig. 22 - Ápice de pĩnula fērtil, mostrando os sinângios (Vide figura seguinte) Exemplar $\mathrm{T} 377(\mathrm{x} 16) \ldots \ldots \ldots \ldots \ldots \ldots$ päg. 63

Fig. 23 - Duas pínulas férteis (Åpice está ampliado na fig. anterior). Observe-se a acentuada decorrência da nervura sobre o ráquis. Exemplar T377 - x 4,0 ..... pág. 

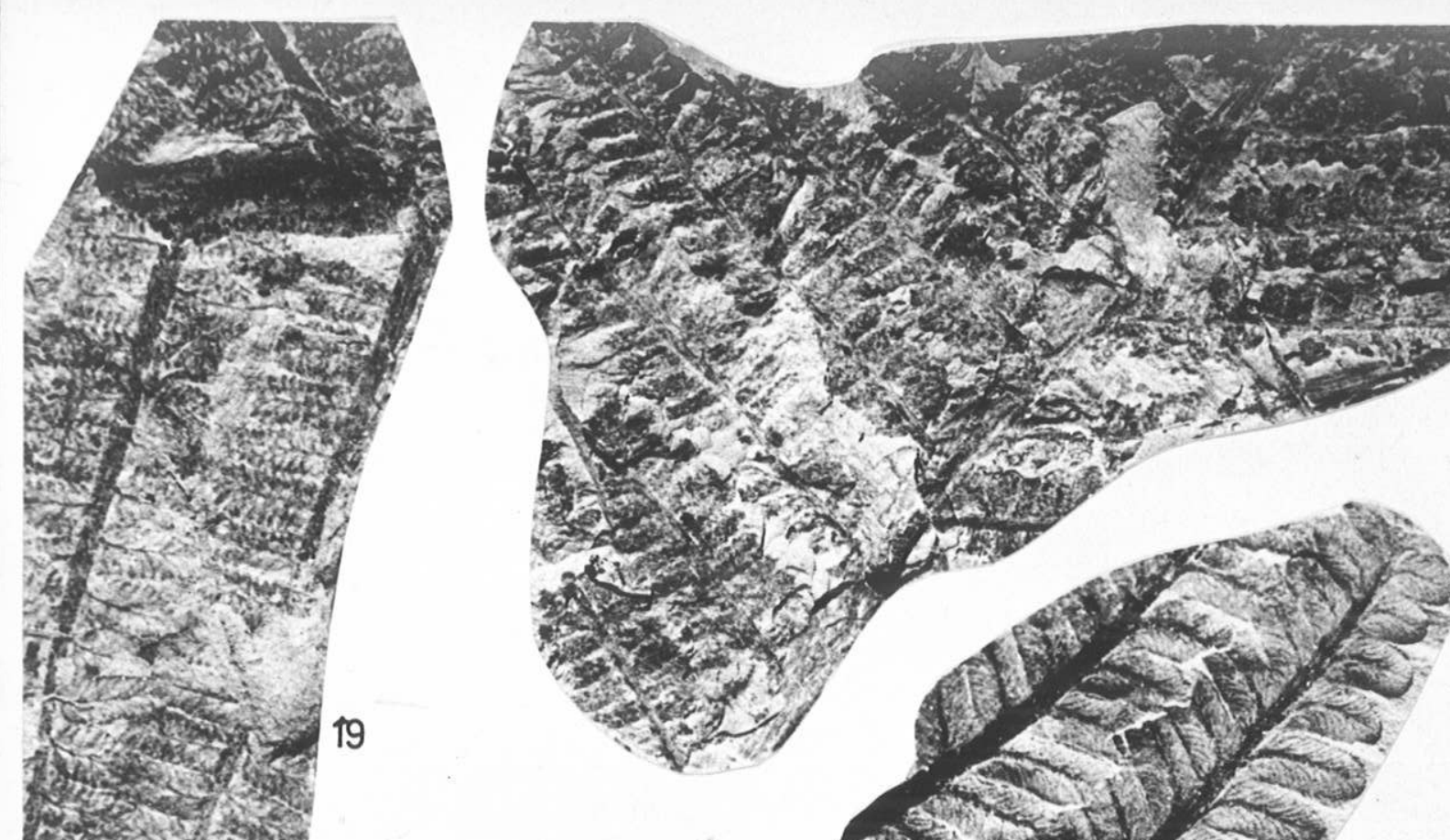

C. 3013

crost son

C. 30 . 35

Q 3250

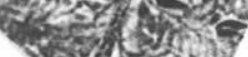
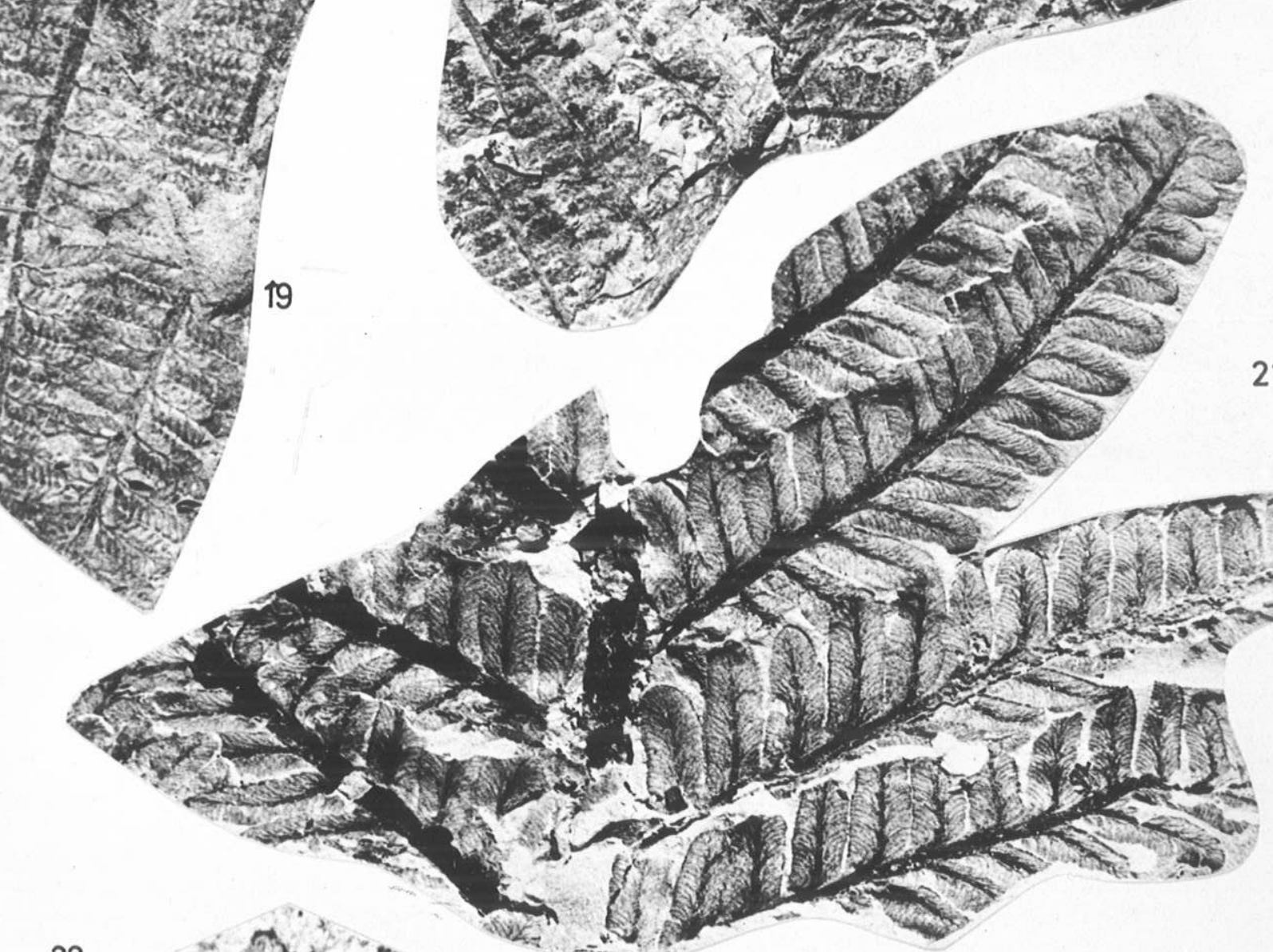

5.

0

22

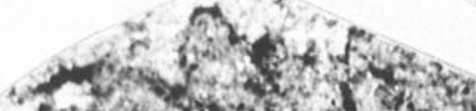

sintsent

B.

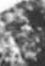

82 in 2 


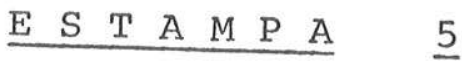
Fig. 24 - 27 - Glossopteris communis Feistmantel Procedência: 24 a 26 - São João do Triunfo 27 - Cambuí

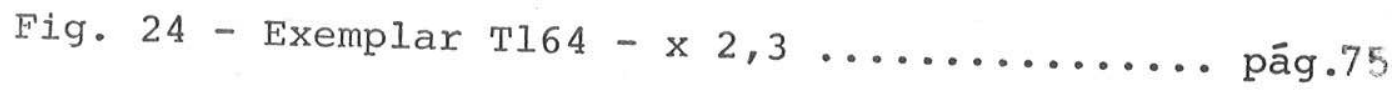

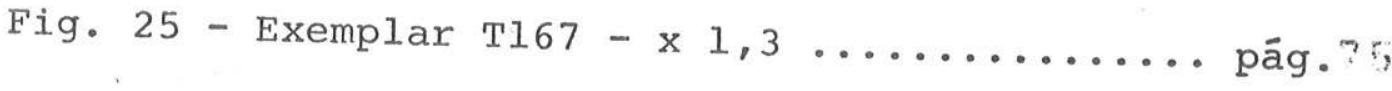

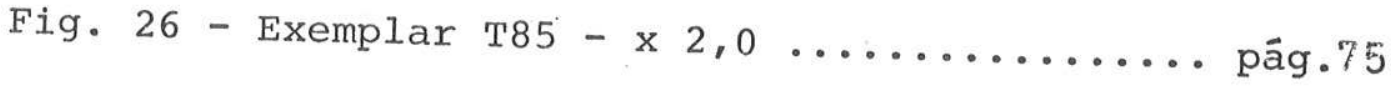

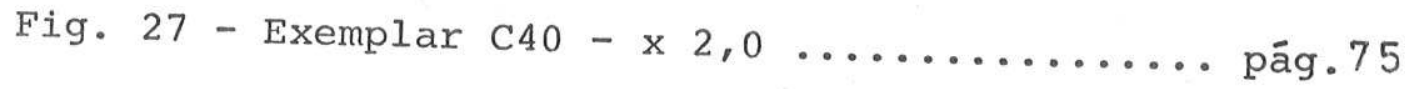



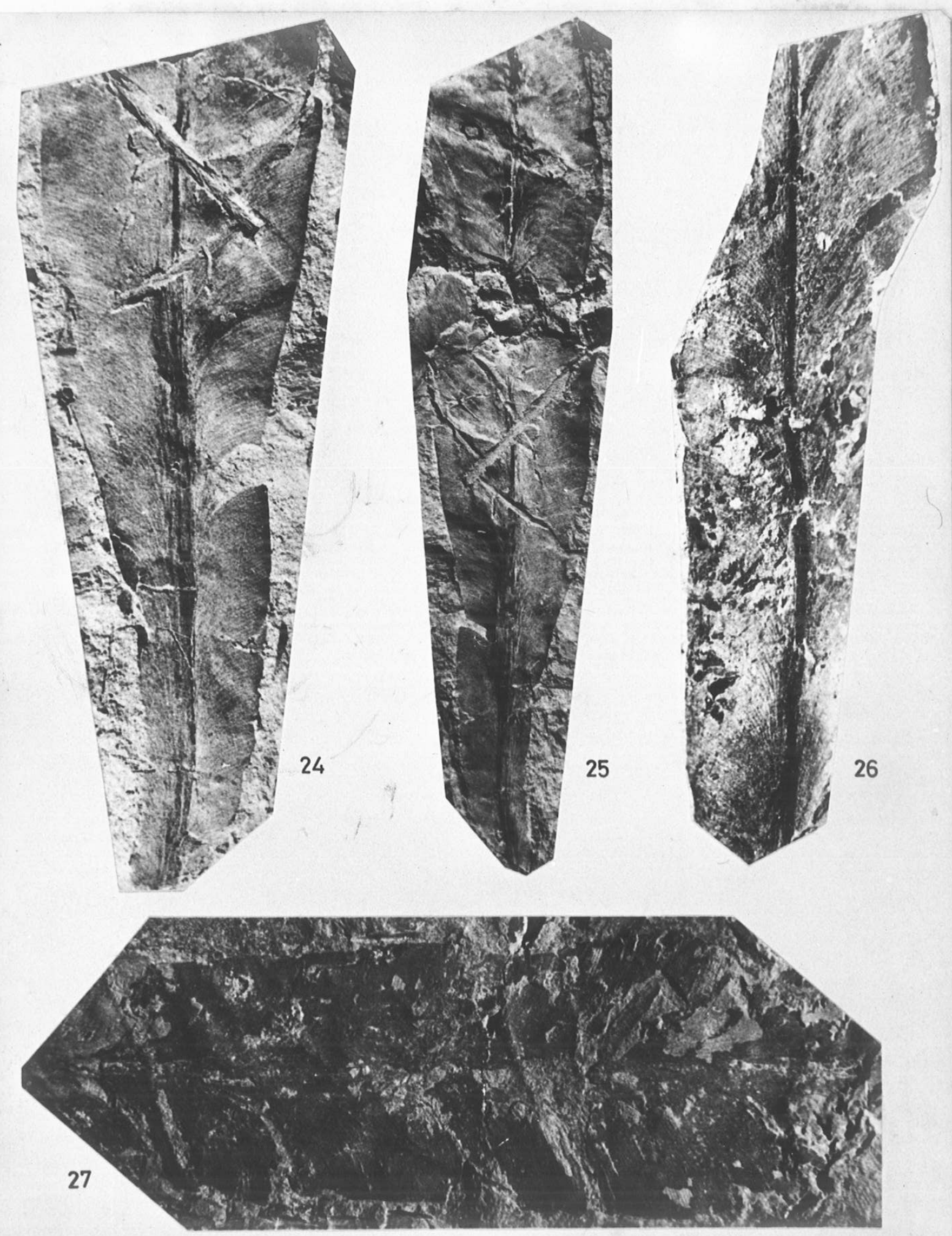
Fig. 28 - Vista de um dos afloramentos de são João do Triunfo de onde pro cede parte do material mais bem conservado......................păg. 16

Fig. 29 - "Campo da Brasileira" da Compa nhia Carbonifera do Cambuí. As galerias, de onde coletamos par te do material, estão a cerca de $120 \mathrm{~m}$ de profundidade................păg. 22

Fig. 30 - "Campo de 5" em Cambuí. Pequena quantidade de material foi aí co letada. Essas galerias, já abandonadas, desabaram dias após.............pāg. 23 

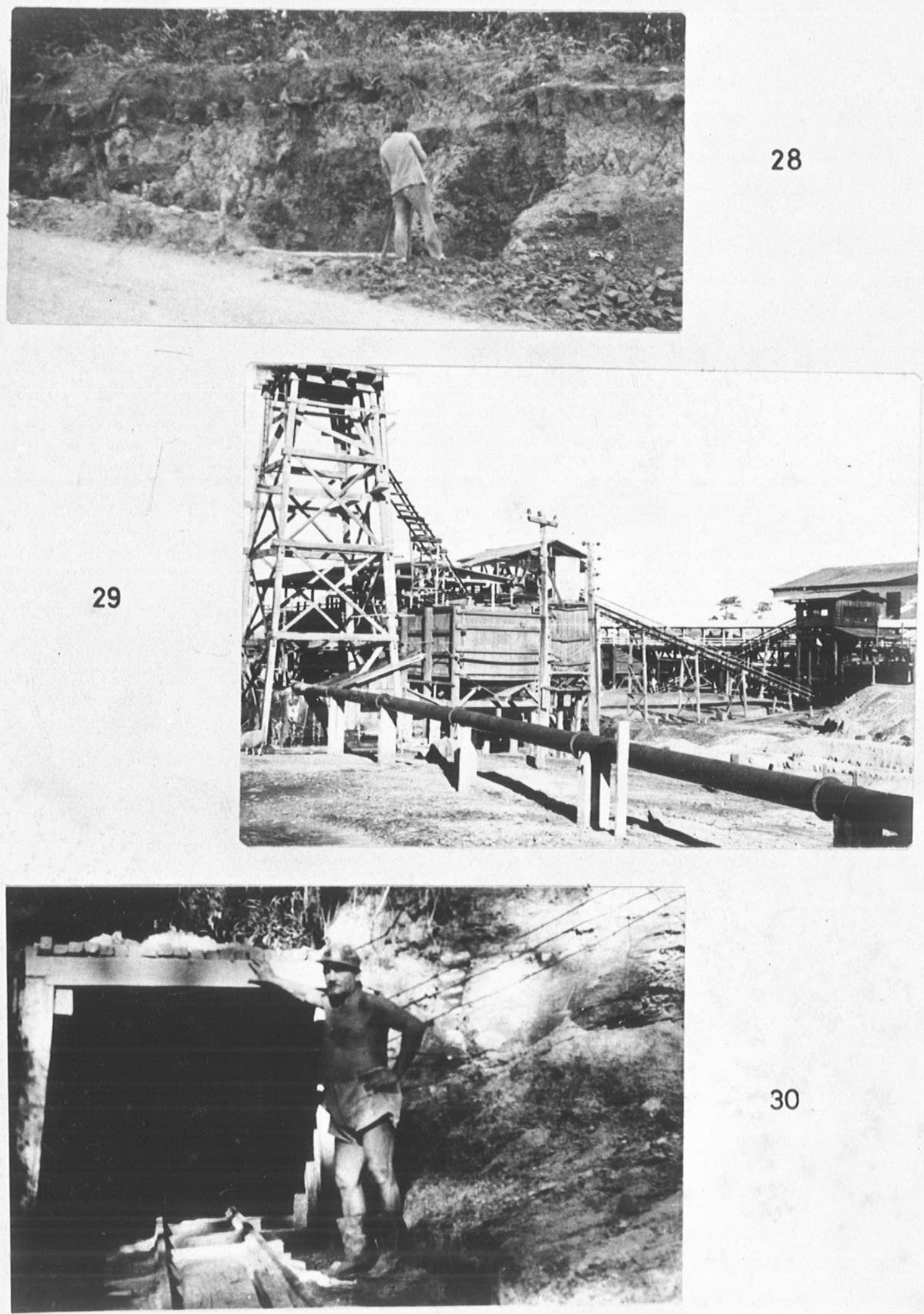